\title{
Hydrology and Geochemistry of a Surface Coal Mine in Northwestern Colorado
}

by Robert S. Williams, Jr., and Gregory M. Clark

\section{U.S. GEOLOGICAL SURVEY}

Water-Resources Investigations Report 92-4187

Prepared in cooperation with the

BUREAU OF LAND MANAGEMENT and the

COLORADO DEPARTMENT OF NATURAL RESOURCES,

MINED LAND RECLAMATION DIVISION 


\title{
U.S. DEPARTMENT OF THE INTERIOR BRUCE BABBITT, Secretary
}

\author{
U.S. GEOLOGICAL SURVEY \\ Gordon P. Eaton, Director
}

The use of trade, product, industry, or firm names is for descriptive purposes only and does not imply endorsement by the U.S. Government.

For additional information write to:

Copies of this report can be purchased from:

District Chief

U.S. Geological Survey

Box 25046, MS 415

Denver Federal Center

Denver, CO 80225
U.S. Geological Survey Earth Science Information Center Open-File Reports Section Box 25286, MS 517 Denver Federal Center Denver, CO 80225 


\section{CONTENTS}

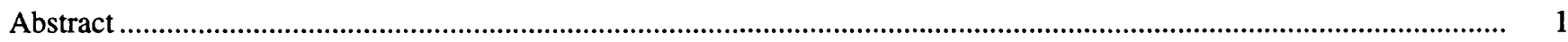

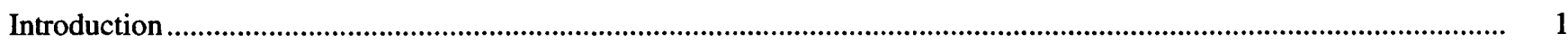

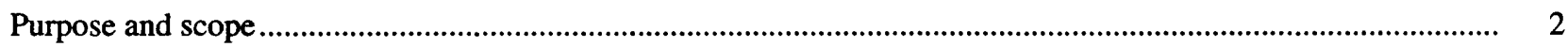

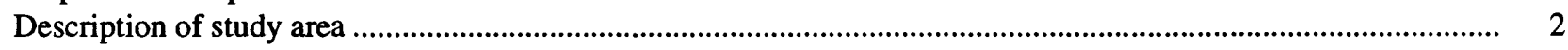

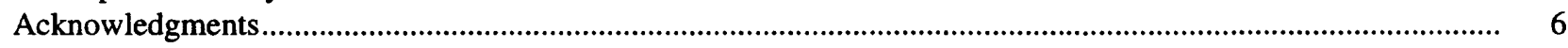

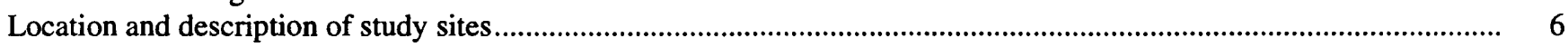

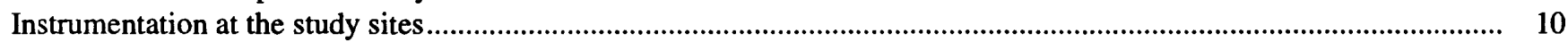

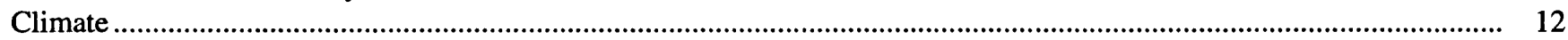

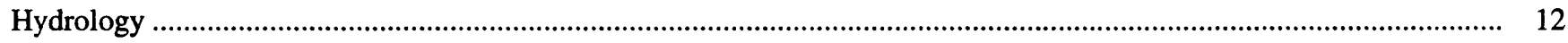

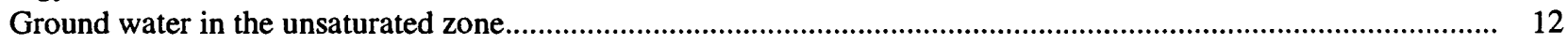

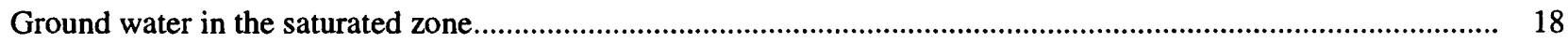

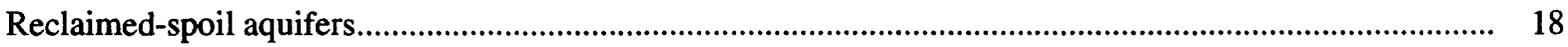

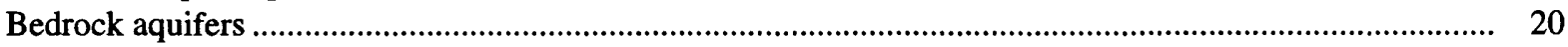

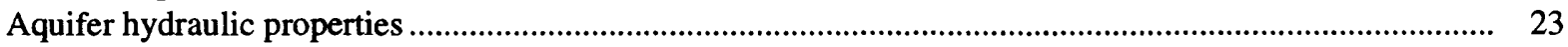

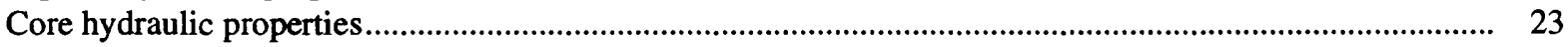

Comparison of aquifer and core hydraulic properties.................................................................................... 26

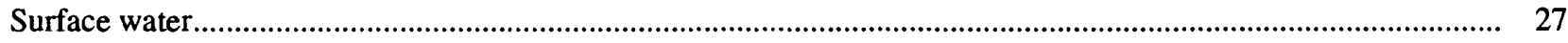

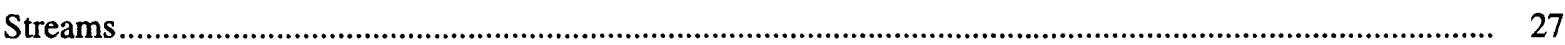

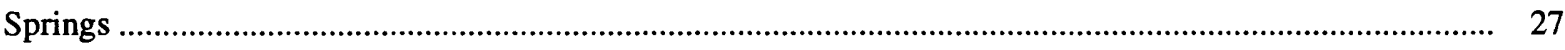

Recharge, discharge, and water balance in reclaimed-spoil aquifers.................................................................. 27

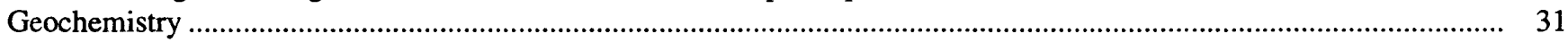

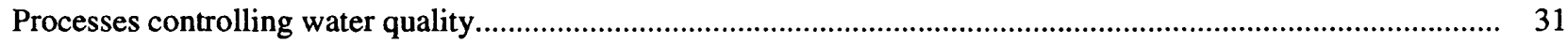

Chemical evolution of water in undisturbed bedrock aquifers ......................................................... 32

Chemical evolution of water in reclaimed-spoil aquifers ........................................................................... 33

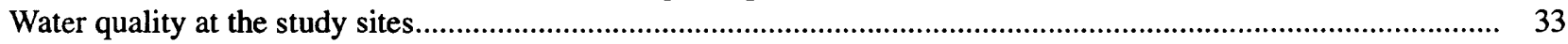

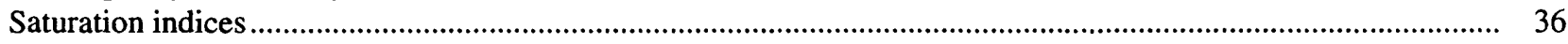

Water quality at sites with undisturbed bedrock aquifers ....................................................................................... 36

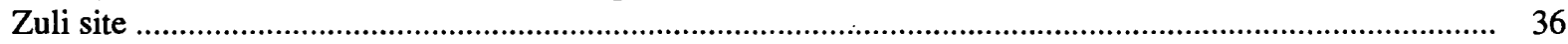

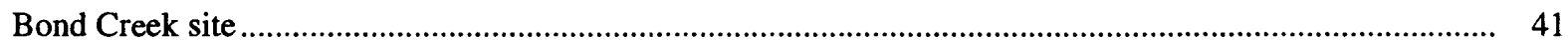

Water quality at sites with bedrock aquifers and reclaimed-spoil aquifers........................................................ 41

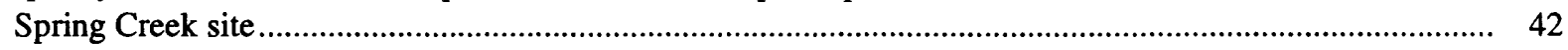

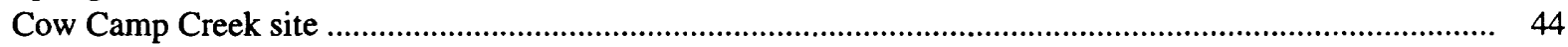

Use of isotopes to characterize recharge and ground-water flow ............................................................ 45

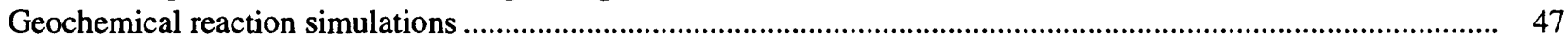

Simulation of recharge and water movement in undisturbed bedrock aquifers........................................... 48

Simulation of recharge and mixing in reclaimed-spoil aquifers ...................................................... 48

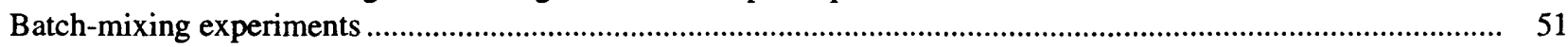

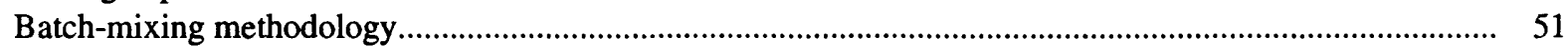

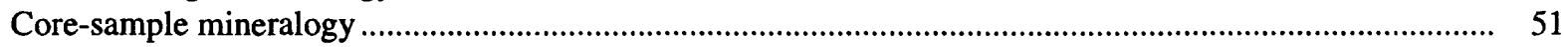

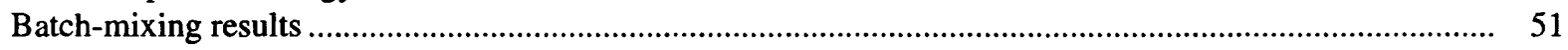

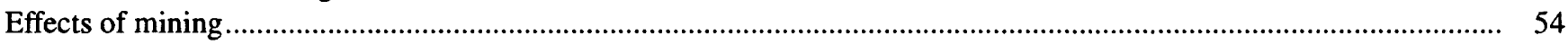

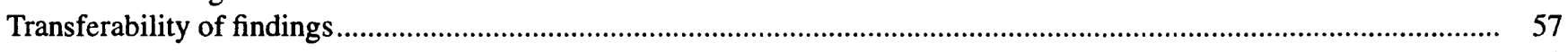

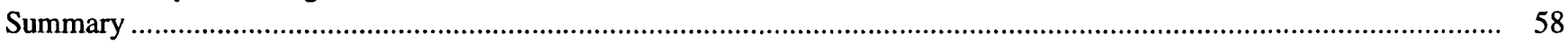

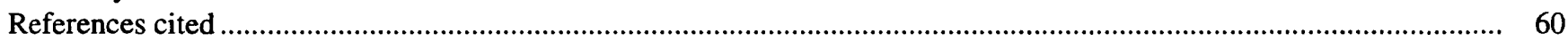




\section{FIGURES}

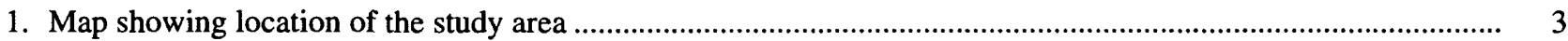

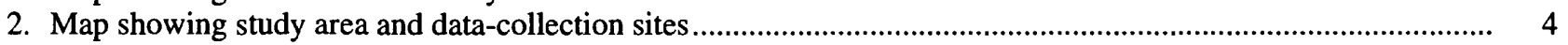

3. Diagram showing general lithologic log for a typical well in the study area ................................................ 5

4. Diagrammatic section showing hydrogeology of reclaimed spoil and bedrock at the study area ........................ 6

5-7. Maps showing data-collection locations and instrumentation at the:

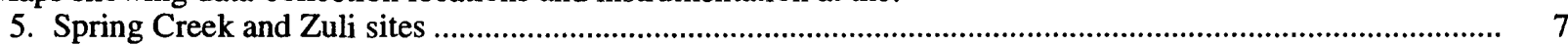

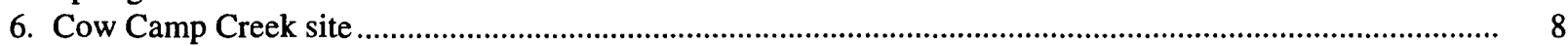

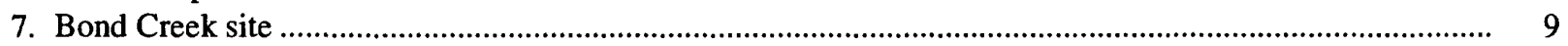

8. Schematic diagram of a lysimeter and a soil-water access tube in the reclaimed spoil.........................................11

9. Graph showing mean soil-porosity profiles for the Spring Creek, Cow Camp Creek, and soil-water control sites

10-12. Graphs showing selected mean soil-water content profiles at the:

10. Spring Creek site

11. Cow Camp Creek site

12. Soil-water control site.

3. Graph showing mean soil-water content for depth intervals of 0 to 7 feet at selected soil-water access tubes at the Spring Creek, Cow Camp Creek, and soil-water control sites, October 1988-October 1989

Hydrograph showing:

14. Instantaneous water levels for selected wells completed in reclaimed spoil at the Spring Creek site, December 1987-October 1989

15. Instantaneous water levels for selected wells completed in reclaimed spoil at the Cow Camp Creek site, December 1987-October 1989

16. Instantaneous hydraulic head for wells completed in bedrock and the water level for one well completed in reclaimed spoil at the Spring Creek site, January 1988-October 1989.

17. Instantaneous hydraulic head for wells completed in bedrock and the water level for one well completed in reclaimed spoil at the Cow Camp Creek site, January 1988-October 1989.

18. Instantaneous hydraulic head for wells completed in bedrock at the Zuli site, January 1988-October 1989.

19. Instantaneous hydraulic head for wells completed in bedrock at the Bond Creek site, January 1988-October 1989.

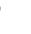

(1)

(1)


33. Diagram showing lithologic units at Cow Camp Creek from which core samples were selected and used for batch-mixing experiments.

\section{TABLES}

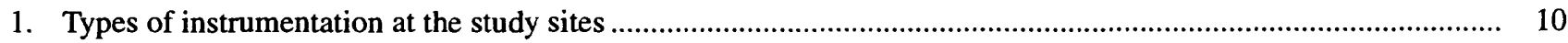

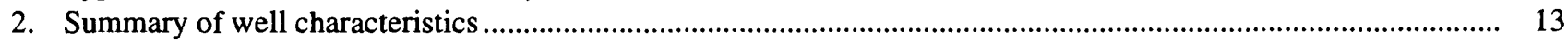

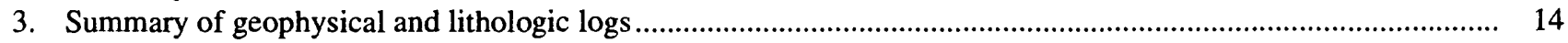

4. Selected hydraulic-conductivity values calculated from aquifer tests and core tests ......................................... 24

5. Porosity, grain density, permeability to air, and hydraulic conductivity of selected core samples collected from the study area

6. Results of calculations for recharge to the reclaimed-spoil aquifers at Spring Creek and Cow Camp Creek from surface recharge and underburden aquifer recharge during water years 1988 and 1989.

7. Statistical summary of $\mathrm{pH}$ and concentrations of selected major water-quality constituents in water samples collected at the Spring Creek, Cow Camp Creek, Zuli, and Bond Creek sites, November 1987-September 1989

8. Mean milliequivalent concentrations for selected ions from the lysimeter, the spring, the reclaimed-spoil aquifer, and the underburden aquifer at the Cow Camp Creek site.

9. Saturation indices for selected mineral phases for water samples collected at the study sites during April 1988

10. Isotope ratio analyses from water samples collected at the study sites during April and May 1988, relative to an arbitrary standard known as standard mean ocean water.

11. Results of mass-balance simulation for recharge and ground-water movement in an undisturbed aquifer using precipitation as the initial solution composition and Bond Creek underburden aquifer water as the end-point solution composition

12. Results of mass-balance simulation for shallow recharge at the Cow Camp Creek site using snowmelt as the initial solution composition and lysimeter water as the end-point solution composition.

13. Results of mass-balance simulation for mixing of soil water and underburden aquifer water to form the reclaimed-spoil aquifer water at Spring Creek using water from the lysimeter and the deep underburden aquifer as initial solution compositions and water from the Spring Creek spring as the end-point solution composition

14. Results of mass-balance simulation for mixing of soil water and underburden aquifer water to form the reclaimed-spoil aquifer water at Cow Camp Creek using water from the lysimeter and the underburden aquifer as initial solution compositions and water from the Cow Camp Creek spring as the end-point solution composition

15. Mineral composition of core samples from the Cow Camp Creek site for the lithologic units from which samples were used for the batch-mixing experiments, in percent by weight.

16. Specific conductance in batch-mixing mixtures after 1 day and 90 days of water-rock contact ........................... 54

17. Selected properties and dissolved-constituent concentrations in batch-mixing water samples............................. 55

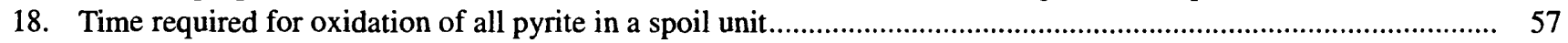




\section{CONVERSION FACTORS AND VERTICAL DATUM}

\begin{tabular}{|c|c|c|}
\hline Multiply & By & To obtain \\
\hline $\begin{array}{r}\text { acre } \\
\text { acre-foot (acre-ft) }\end{array}$ & $\begin{array}{l}0.405 \\
0.001233\end{array}$ & $\begin{array}{l}\text { hectare } \\
\text { cubic hectometer }\end{array}$ \\
\hline cubic centimeter $\left(\mathrm{cm}^{3}\right)$ & 0.061 & cubic inch \\
\hline cubic foot $\left(\mathrm{ft}^{3}\right)$ & 0.02832 & cubic meter \\
\hline cubic foot per second $\left(\mathrm{ft}^{3} / \mathrm{s}\right)$ & 0.02832 & cubic meter per second \\
\hline foot (ft) & 0.3048 & meter \\
\hline foot per day $(\mathrm{ft} / \mathrm{d})$ & 0.3048 & meter per day \\
\hline foot per foot $(\mathrm{ft} / \mathrm{ft})$ & 1.0 & meter per meter \\
\hline foot per second $(\mathrm{ft} / \mathrm{s})$ & 0.3048 & meter per second \\
\hline gallon per minute ( $\mathrm{gal} / \mathrm{min})$ & 0.0630 & liter per second \\
\hline gram $(\mathrm{g})$ & 0.03527 & ounce, avoirdupois \\
\hline gram per cubic centimeter $\left(\mathrm{g} / \mathrm{cm}^{3}\right)$ & 62.4 & pound per cubic foot \\
\hline inch (in.) & 2.54 & centimeter \\
\hline inch per year (in./yr) & 2.54 & centimeter per year \\
\hline liter per cubic foot $\left(\mathrm{L} / \mathrm{ft}^{3}\right)$ & 0.264 & gallon per cubic foot \\
\hline micrometer $(\mu \mathrm{m})$ & $39.37 \times 10^{-6}$ & inch \\
\hline mile $(\mathrm{mi})$ & 1.609 & kilometer \\
\hline mile per hour $(\mathrm{mi} / \mathrm{h})$ & 1.609 & kilometer/hour \\
\hline millidarcy $(\mathrm{mD})$ & $3.17 \times 10$ & foot per second \\
\hline milligram (mg) & $35.27 \times 10^{-5}$ & ounce, avoirdupois \\
\hline square foot $\left(\mathrm{ft}^{2}\right)$ & 0.0929 & square meter \\
\hline square mile $\left(\mathrm{mi}^{2}\right)$ & 2.59 & square kilometer \\
\hline
\end{tabular}

Degree Fahrenheit $\left({ }^{\circ} \mathrm{F}\right)$ may be converted to degree Celsius $\left({ }^{\circ} \mathrm{C}\right)$ by using the following equation:

$$
{ }^{\circ} \mathrm{C}=5 / 9\left({ }^{\circ} \mathrm{F}-32\right) \text {. }
$$

The following items and abbreviations also are used in this report:

microgram per liter $(\mu \mathrm{g} / \mathrm{L})$

microsiemens per centimeter at 25 degrees Celsius $(\mu \mathrm{S} / \mathrm{cm})$

milligram per liter $(\mathrm{mg} / \mathrm{L})$

millimole per kilogram $(\mathrm{mmol} / \mathrm{kg})$

mole (mol)

part per thousand (per mil)

picocurie per liter $(\mathrm{PCi} / \mathrm{L})$

NGVD: In this report "sea level" refers to the National Geodetic Vertical Datum of 1929 (NGVD of 1929)-a geodetic datum derived from a general adjustment of the first-order level nets of both the United States and Canada, formerly called Sea Level Datum of 1929. 


\title{
Hydrology and Geochemistry of a Surface Coal Mine in Northwestern Colorado
}

\author{
By Robert S. Williams, Jr., andGregory M. Clark
}

\section{Abstract}

The hydrology and geochemistry of a reclaimed coal mine in northwestern Colorado were monitored during water years 1988 and 1989. Some data also were collected in water years 1987 and 1990.

This report describes (1) the sources of hydrologic recharge to and discharge from reclaimed spoil, (2) the relative contributions of recharge to the reclaimed spoil aquifer from identified source waters and the rate of water movement from those sources to the reclaimed spoil, and (3) the geochemical reactions that control water quality in reclaimed spoil.

The study area was at a dip-slope coal mine encompassing about 7 square miles with land slopes of varying aspect. The area was instrumented and monitored at five sites; two sites had unmined and reclaimed-spoil areas adjacent to each other and three sites were unmined. The mined areas had been reclaimed. Instrumentation at the study sites included 1 climate station, 3 rain gages, 19 soil-water access tubes, 2 lysimeters, 18 wells completed in bedrock, 7 wells completed in reclaimed spoil, and 2 surface-water gaging stations.

The results of the study indicate that the reclaimed spoil is recharged from surface recharge and underburden aquifers. Discharge, as measured by lysimeters, was about 3 inches per year and occurred during and after snowmelt. Hydraulic-head measurements indicated a potential for ground-water movement from deeper to shallower aquifers. Water levels rose in the reclaimed-spoil aquifer and spring discharge at the toe of the spoil slopes increased rapidly in response to snowmelt.

Water chemistry, stable isotopes, geochemical models, and mass-balance calculations indicate that surface recharge and the underburden aquifers each contribute about 50 percent of the water to the reclaimed-spoil aquifers. Geochemical information indicates that pyrite oxidation and dissolution of carbonate and efflorescent sulfate minerals control the water chemistry of the reclaimed-spoil aquifer.

\section{INTRODUCTION}

Surface coal mining has short-term and potentially long-term effects on the ecology of the area being mined. As a result, the ecosystem of the area, including the local hydrology, also may be affected during and after the mining operation. Representatives of the mining industry and management and regulatory agencies who oversee the mining are responsible for predicting and documenting the magnitude and the duration of hydrologic change in the mine-area ecosystem.

Surface coal-mining operations occurring in northwestern Colorado commonly disturb hundreds to thousands of acres of land at a mine site. During surface mining, the vegetation, topsoil, and bedrock overlying the coal are removed, the coal is mined, spoil is replaced, and the area is reclaimed. Reclaimed spoil, as described in this report, is material that has been excavated from the mine pit and then replaced, regraded, topsoiled, and revegetated. Reclaimed spoil is a heterogeneous mixture of material removed during the mining process commonly containing clay, shale, siltstone, sandstone, and some coal. In most instances, special sorting or handling of materials is not required; therefore, the distribution of the earthen material within the reclaimed spoil is random. In the case of mines that encounter acid- or toxic-forming materials, special handling of spoil can be required.

Knowledge of the hydrology and geochemistry of reclaimed spoil and adjacent hydrologic systems is needed to properly evaluate the potential effects of coal mining on the hydrologic system of the area. Mine operators use the information to plan removal of the coal and to verify effects on the hydrologic systems to obtain bond release after reclamation. Management and regulatory agencies use the information to understand the hydrologic systems, to lease and permit the land, to oversee active mining operations, to evaluate 
mine operators' projections of probable hydrologic consequences, and to complete bond release decisions.

In 1986, the U.S. Geological Survey, in cooperation with the Bureau of Land Management and the Colorado Department of Natural Resources, Mined Land Reclamation Division, began a study to determine the processes and properties that control the hydrology and geochemistry of reclaimed coal spoils at a surface coal mine in northwestern Colorado. The information obtained also was used to estimate the magnitude and duration of hydrologic change following surface mining of coal. Data and methodology transferability to other areas also was a consideration of the study. To help determine effects of mining, study sites with unmined and reclaimed-spoil conditions were selected. Because the aspect of mined land slopes in northwestern Colorado is variable, the study sites also were selected to represent areas having land slopes with variable aspects.

\section{Purpose and Scope}

This report describes (1) the sources of hydrologic recharge to and discharge from reclaimed spoil, (2) the relative contributions of recharge to the reclaimed spoil aquifer from identified source waters and the rate of water movement from those sources to the reclaimed spoil, and (3) the geochemical reactions that control water quality in reclaimed spoil.

Monitoring equipment and instrumentation were installed in the summer of 1987. Climatologic, soilwater, ground-water, geologic, surface-water, and water-quality data were collected at five sites. Data were collected during water years 1988 and 1989 with some data being collected in water years 1987 and 1990. The data collected for this study are in a report by Williams and others (1992).

\section{Description of Study Area}

The study area is located at the Seneca II Coal Mine in northwestern Colorado (fig. 1). The Seneca II Coal Mine is about $20 \mathrm{mi}$ west of Steamboat Springs, Colorado. The area is shown on the U.S. Geological Survey topographic maps of the Milner and Mount Harris quadrangles (fig. 2). Elevation of the area ranges from about 6,800 to $8,000 \mathrm{ft}$. The vegetation is primarily a sagebrush/grassland community with scattered Gambel (scrub) oak, serviceberry, and aspen.

The exposed rock sequence in the study area is a portion of the lower unit of the Williams Fork Formation of Late Cretaceous age. This unit consists of soft sandstones, sandy shales, thin beds of dark-gray to black shale, and coal beds (fig. 3). The coal beds of interest in this study are the Lennox and the Wadge, which in the study area range in depth from 0 to more than $100 \mathrm{ft}$. A prominent geologic feature in the study area is the Tow Creek anticline, a northeastwardtrending asymmetrical fold (Bass and others, 1955) (fig. 1). The axis of the anticline approximately bisects the mine; bedrock east of the anticlinal axis dips to the east, and bedrock west of the axis dips to the west. The eastern part of the area is drained by Bond Creek, Cow Camp Creek, and other unnamed streams that are tributary to Fish Creek. The western part of the area is drained by Little Grassy Creek, which is tributary to Grassy Creek. In the southern part of the study area at the southern tip of the anticline, rocks dip to the south.

The surface coal mines in the area are known as dip-slope strip mines. Coal-mining depth generally does not exceed $100 \mathrm{ft}$ due to excessive costs and environmental factors. Coal from the area is subbituminous and bituminous. The coal is burned at nearby coal-fired generating plants or is shipped by train to more distant consumers.

Several features characterize reclaimed spoil and the surrounding undisturbed bedrock. A diagram showing hydrogeology of reclaimed spoil and the surrounding bedrock is shown in figure 4 . Reclaimed spoil, in general, is more permeable than undisturbed bedrock. As a result, rates of water infiltration and percolation in the reclaimed spoil are larger than in adjacent undisturbed areas. Because more mineral surfaces are exposed to weathering following fragmentation, excavation, and replacement of undisturbed bedrock, the quantity and rates of chemical reactions in the spoil material also are increased.

A number of confined and semiconfined aquifers exist throughout the lithologic sequence in the undisturbed bedrock of the study area (Williams and Clark, 1992). Wells located near the toe of slopes and completed in these undisturbed bedrock aquifers commonly flow at land surface. Flow rates in these wells generally are less than $5 \mathrm{gal} / \mathrm{min}$. Shut-in hydraulic-head measurements for flowing wells in the study area range from a few feet to tens of feet above land surface (Williams and others, 1992).

Bedrock adjacent to and underlying the mine pit could potentially be altered by mining operations. Bedrock could be fractured and confining layers could be breached; thus, water previously confined in distinct lithologic units beneath the excavated material may flow into the reclaimed spoil. A different set of flow conditions could promote downward vertical movement of water from the reclaimed spoil into the underlying bedrock aquifers. 

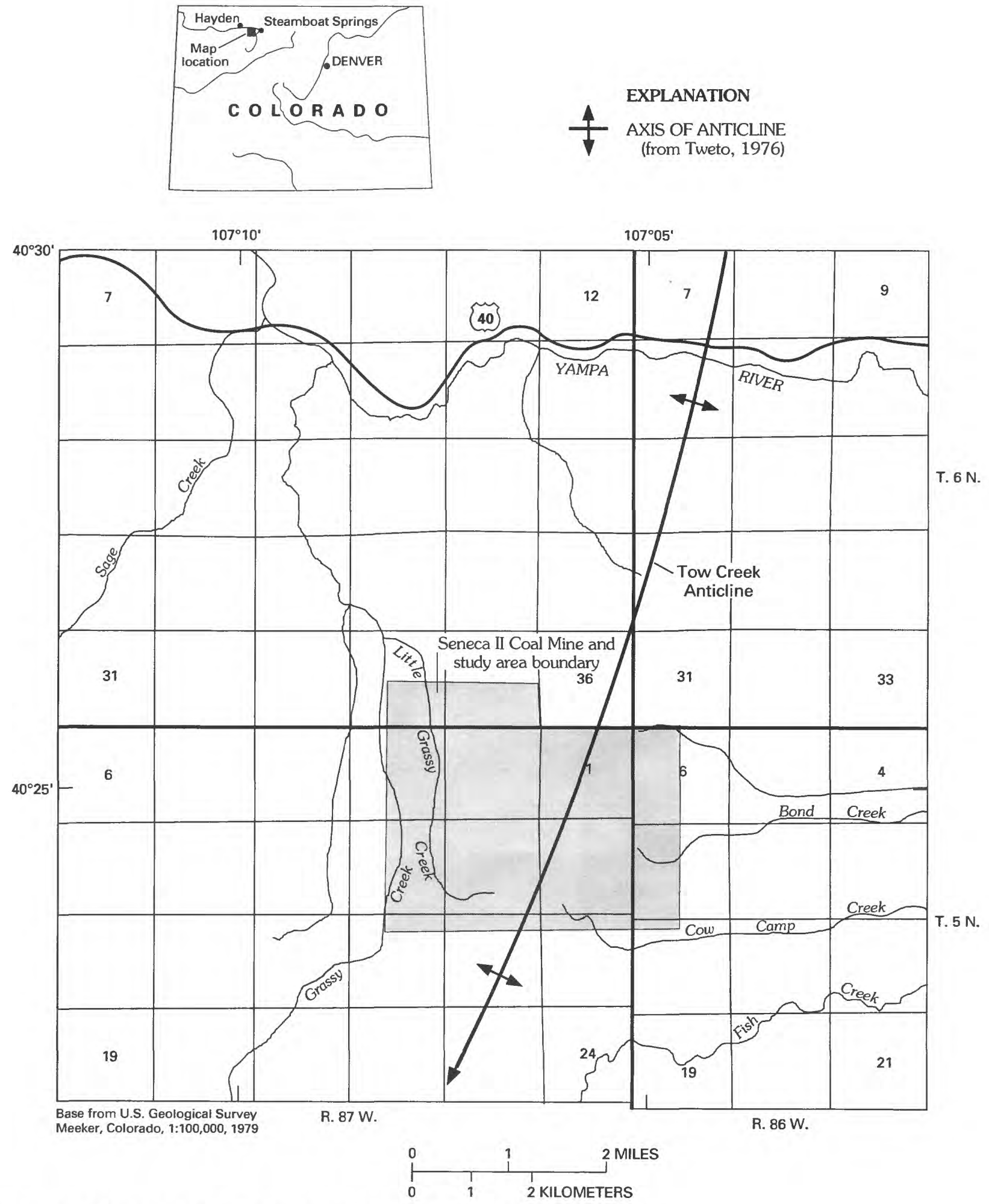

Figure 1. Location of the study area (modified from Clark and Williams, 1990). 


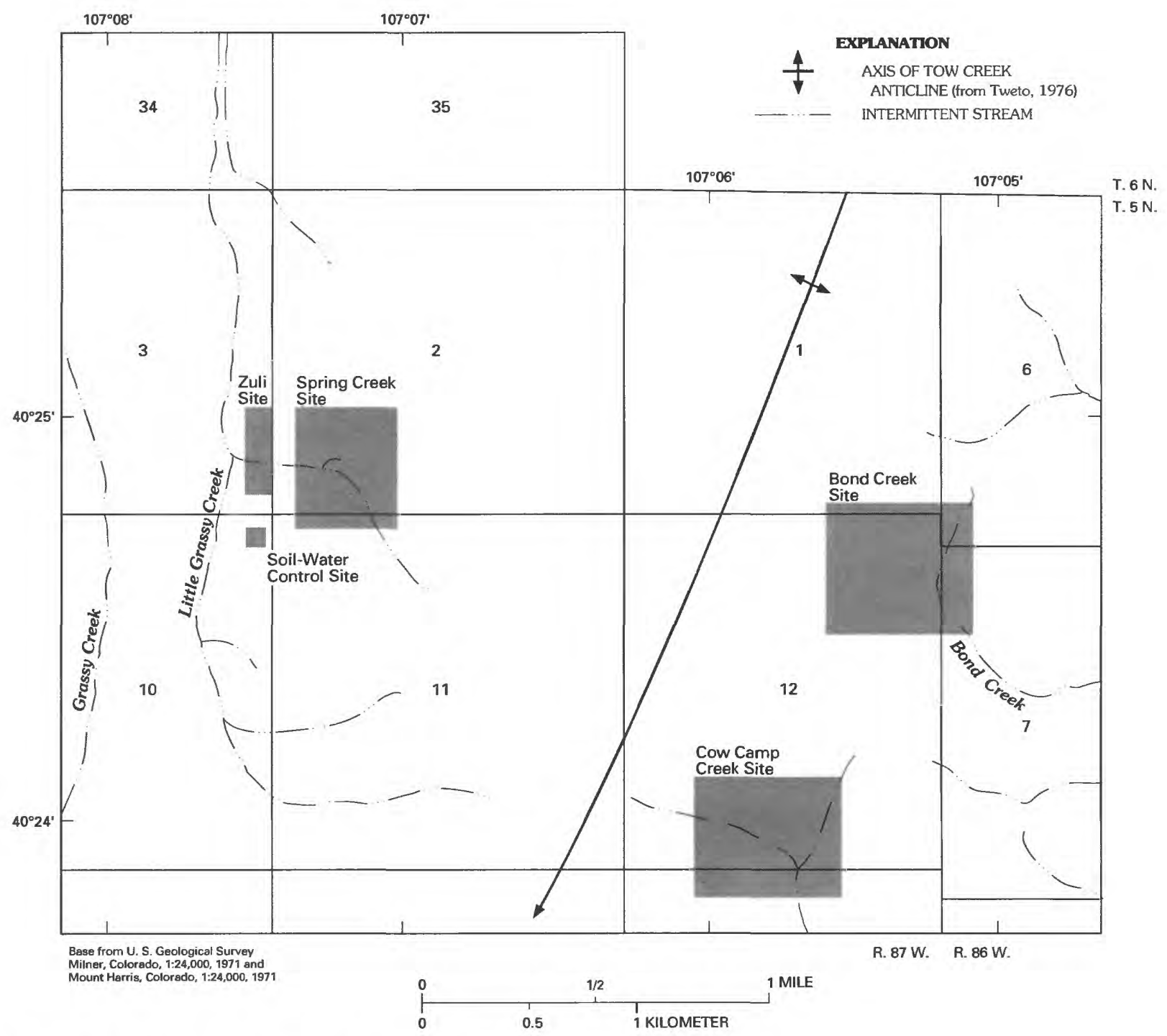

Figure 2. Study area and data-collection sites. 


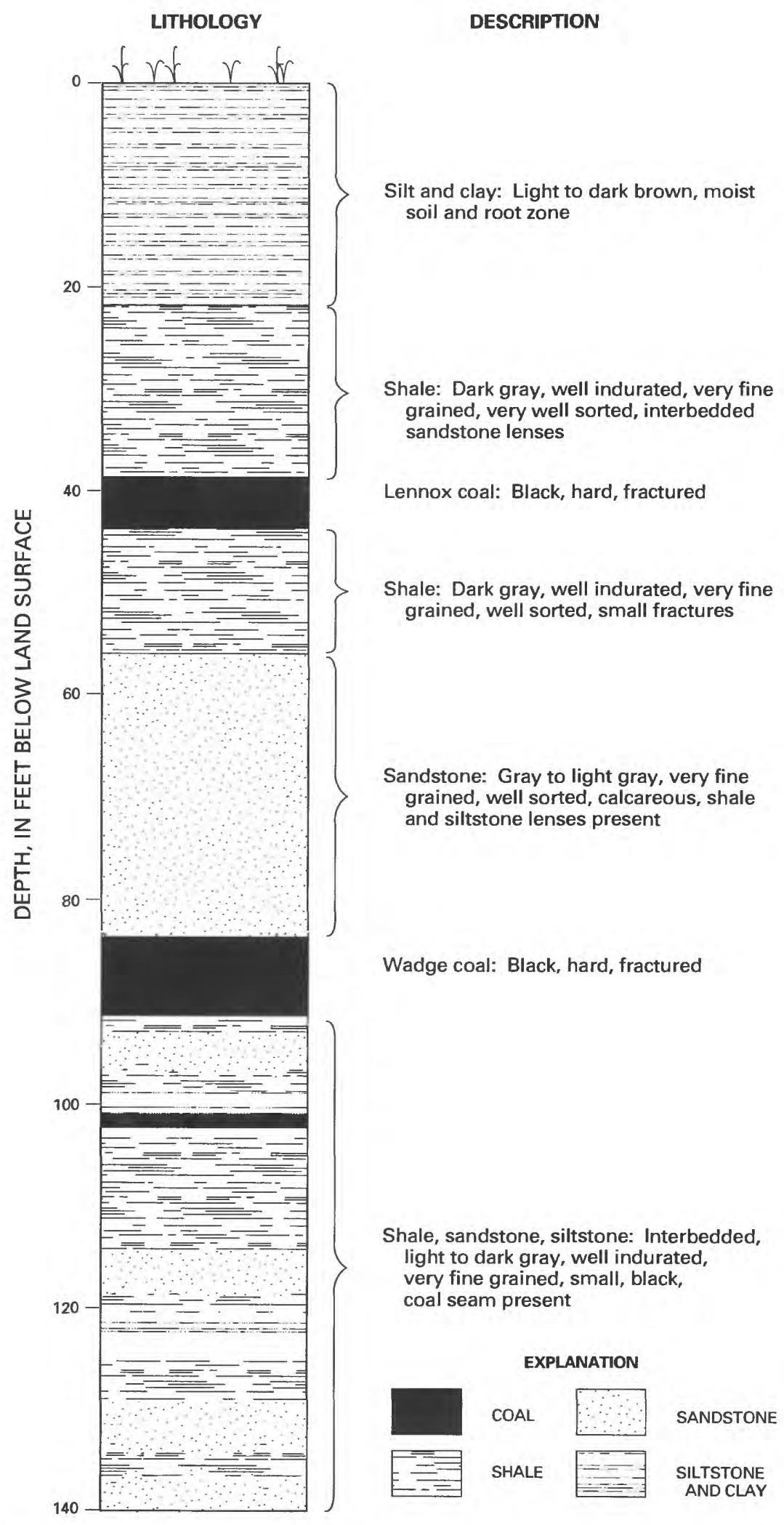

Figure 3. General lithologic log for a typical well in the study area. 


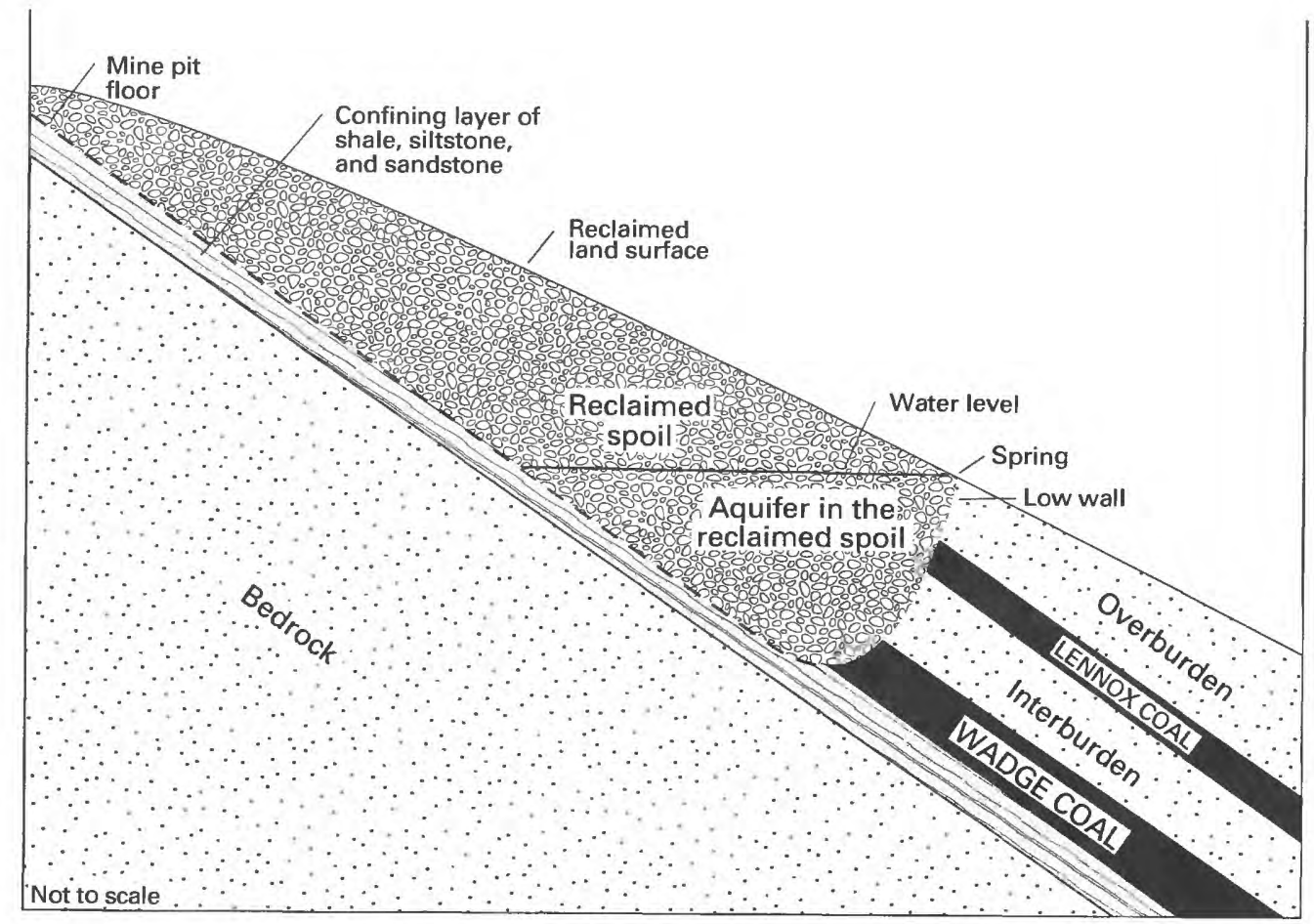

Figure 4. Hydrogeology of reclaimed spoil and bedrock at the study area (modified from Clark and Williams, 1990).

An aquifer can develop in the reclaimed spoil (fig. 4) following mining in response to infiltration, percolation, and inflow of water from the bedrock. These unconfined spoil aquifers are bounded by the mine pit side and low walls saturating the spoil materials at the toe of the slope. Because the permeability of the surrounding undisturbed bedrock usually is much less than the reclaimed spoil, the water level in these spoil aquifers may eventually rise to the land surface forming a spring at the low wall. Discharge from spoilaquifer springs in the semiarid environment of northwestern Colorado could be beneficial if the quality of the water was acceptable for potential uses, such as irrigation or livestock watering. However, the discharge from the springs in this study area contained more total dissolved solids than the local surface-water system.

\section{Acknowledgments}

Personnel from the Peabody Coal Company at the Flagstaff, Arizona, headquarters office and at the Seneca II Coal Mine supplied technical information and machinery throughout the study. Bulldozers and backhoes were provided during construction phases, roads were snowplowed and graded as needed, and wells were surveyed and mapped at all sites. Personnel from the Bureau of Land Management and the Colorado Department of Natural Resources, Mined Land Reclamation Division, assisted with the installation of data-collection facilities and the collection of data. The work and assistance from all parties was greatly appreciated.

\section{LOCATION AND DESCRIPTION OF STUDY SITES}

Data were collected at five sites in the study area. The sites were chosen to represent unmined, partially mined, and reclaimed-spoil conditions with different aspects. Two of the sites, Spring Creek (figs. 2 and 5) and Cow Camp Creek (figs. 2 and 6), have unmined and reclaimed-spoil areas adjacent to each other. The Zuli site (figs. 2 and 5) is unmined and probably will not be mined. The Zuli site was selected to establish the ground-water-quality conditions of an unmined site and to compare these conditions to the water quality at reclaimed-spoil sites. The Bond Creek site (figs. 2 and 7) was selected to determine baseline conditions in ground-water wells before mining begins and then 


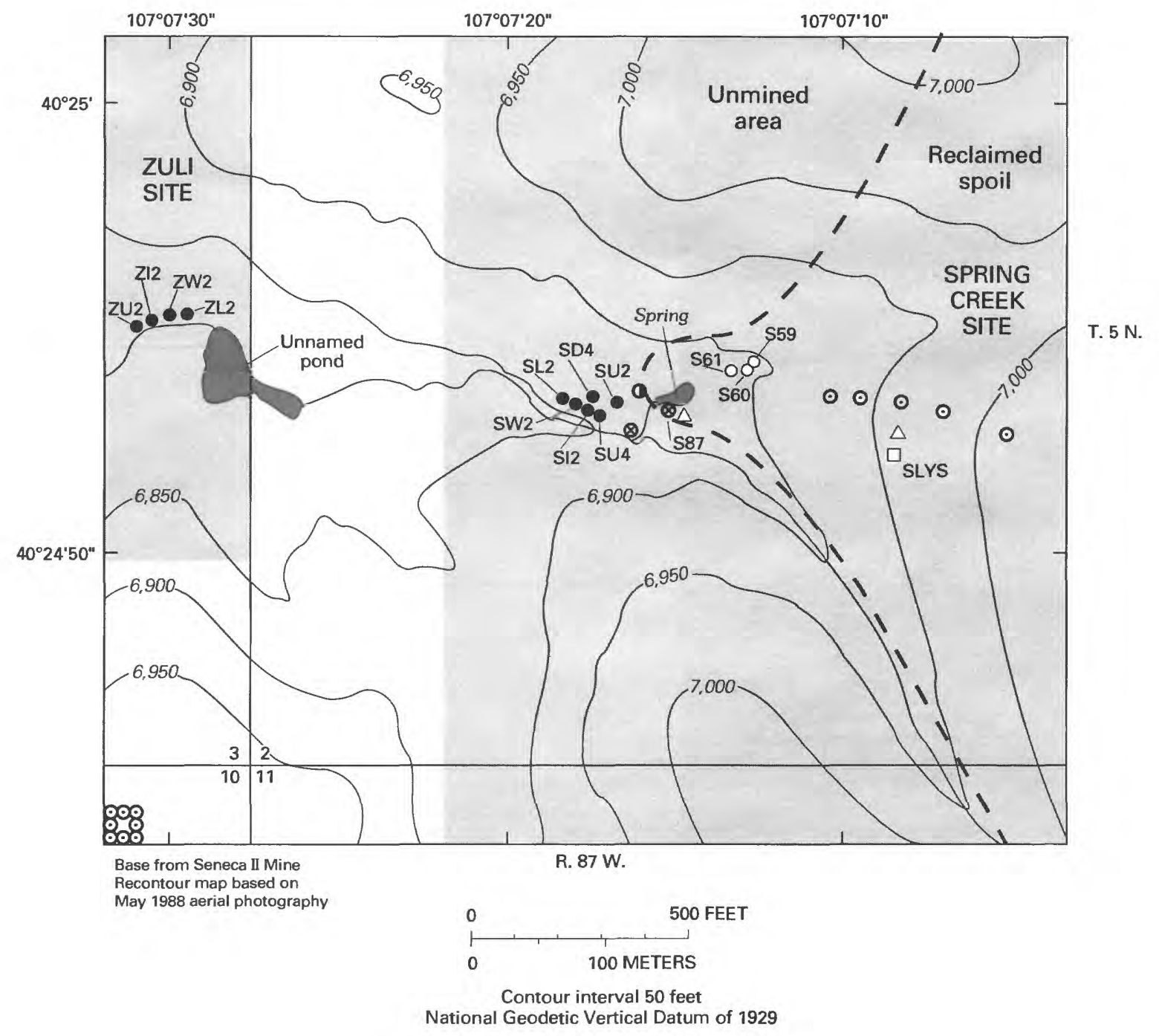

EXPLANATION

\begin{tabular}{|c|c|c|c|}
\hline & STUDY SITES & & $\begin{array}{l}\text { WEIGHING-BUCKET } \\
\text { PRECIPITATION GAGE }\end{array}$ \\
\hline-- & $\begin{array}{l}\text { APPROXIMATE BOUNDARY } \\
\text { OF RECLAIMED SPOIL }\end{array}$ & 0 & SOIL-WATER ACCESS TUBE \\
\hline & $\begin{array}{l}\text { WELL COMPLETED IN BEDROCK } \\
\text { AND WELL NAME (TABLE 2) }\end{array}$ & $\stackrel{0}{0}$ & $\begin{array}{l}\text { SURFACE-WATER-GAGING STATION } \\
\text { CLIMATE STATION }\end{array}$ \\
\hline $0^{500}$ & $\begin{array}{l}\text { WELL COMPLETED IN RECLAIMED SPOIL } \\
\text { AND WELL NAME (TABLE 2) }\end{array}$ & @8 & SOIL-WATER CONTROL SITE \\
\hline$\square$ & $\begin{array}{l}\text { LYSIMETER AND SOIL WATER } \\
\text { ACCESS TUBE }\end{array}$ & & \\
\hline
\end{tabular}

Figure 5. Data-collection locations and instrumentation at the Spring Creek and Zuli sites. 


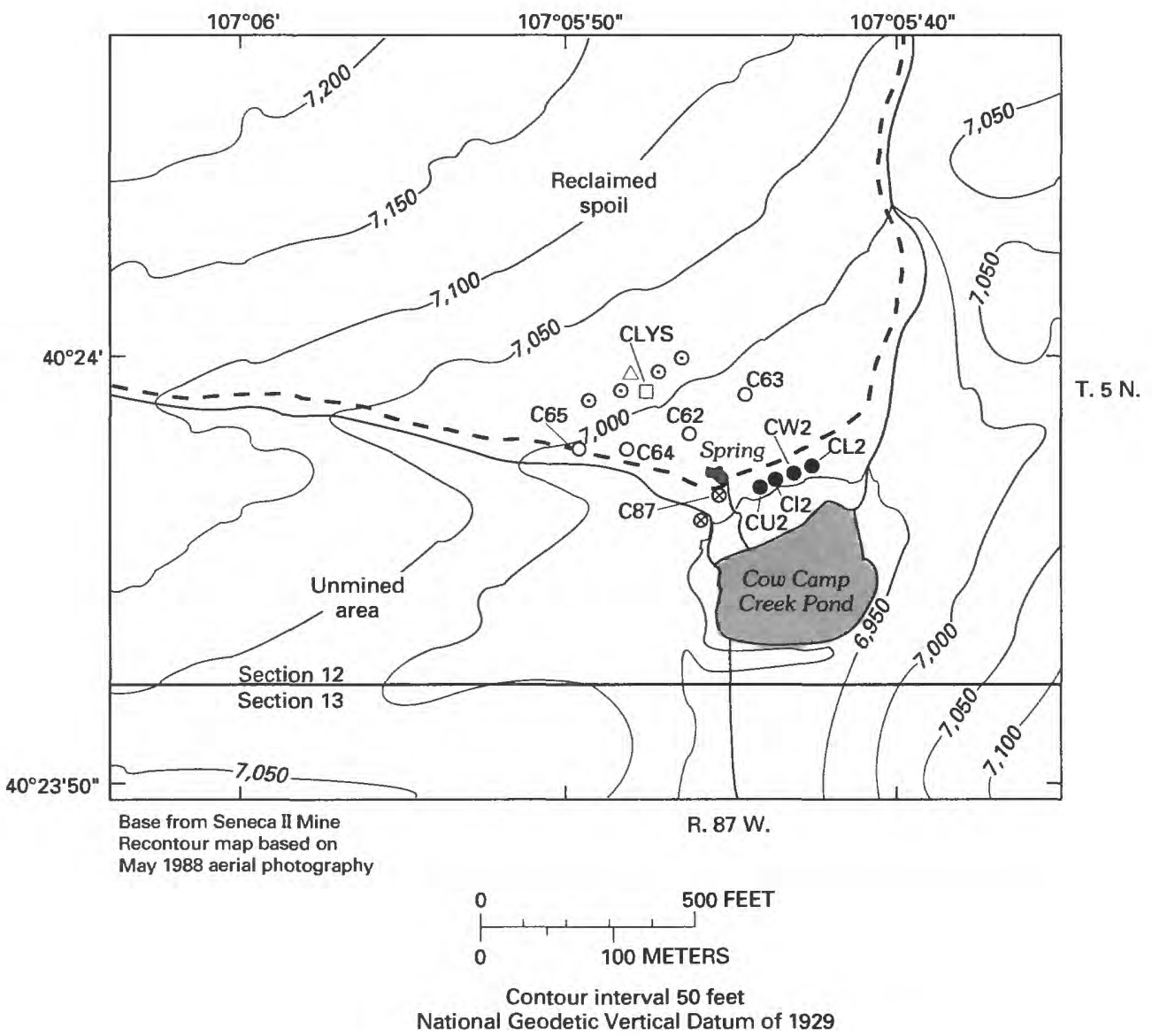

EXPLANATION

$\begin{array}{cl}- & \text { APPROXIMATE BOUNDARY } \\ \mathrm{Cl} 2 & \text { OF RECLAIMED SPOIL } \\ \mathrm{C} 65 & \text { WELL COMPLETED IN BEDROCK } \\ \square & \text { WELL COMPLETED IN RECLAIMED SPOIL } \\ \triangle & \text { WYSIMETER AND SOIL-WATER ACCESS TUBE } \\ \odot & \text { SOIL-WATER ACCESS TUBE } \\ \otimes & \text { SURFACE-WATER GAGING STATION }\end{array}$

Figure 6. Data-collection locations and instrumentation at the Cow Camp Creek site. 


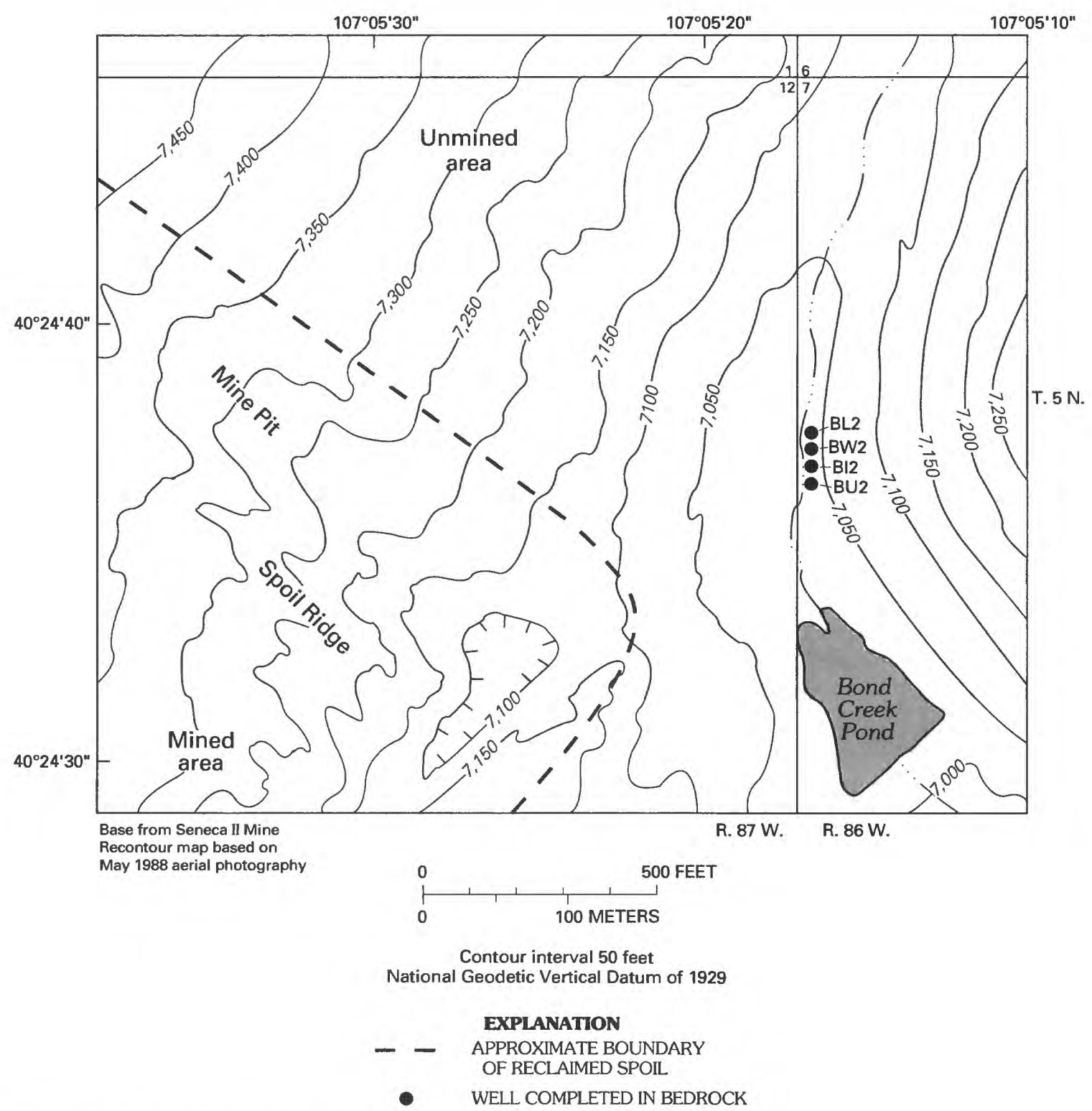

Figure 7. Data-collection locations and instrumentation at the Bond Creek site. 
monitor changes that occur as mining progresses. When equipment installation began in 1987, the progress of the mining operation had not yet reached a location in which it affected the Bond Creek groundwater wells (fig. 7). By 1990, the entire slope west of the Bond Creek wells had been mined. The soil-water control site (fig. 2) is an area that probably will never be mined. This site was selected to compare the snowpack, soil-water content, and soil dry density of an unmined site with reclaimed-spoil sites.

The slope and aspect between sites and within each site varies. However, in general, study sites have slopes of about $0.2 \mathrm{ft} / \mathrm{ft}$. The general aspect of the Spring Creek, Zuli, and soil-water control sites is westerly. The aspect of the Cow Camp Creek site is southeasterly, and the aspect of the Bond Creek site is east-southeast. The study area encompasses about $7 \mathrm{mi}^{2}$.

Reclamation was completed at the Spring Creek and Cow Camp Creek sites during the period of this study. As necessary, periodic intervention by mine operators is needed to sustain reclamation. Parts of the Bond Creek site had been regraded by the summer of 1990. However, a large part of the Bond Creek site had not been reclaimed by the time this study had been completed.

\section{INSTRUMENTATION AT THE STUDY SITES}

A variety of instruments were installed in 1987 to monitor the hydrology of the study sites (table 1). The instrumentation was used to collect data pertaining to the climatological, soil-water, ground-water, and surface-water conditions at the study sites. The data collected during the study are compiled in a report by Williams and others (1992).
Climatologic conditions were monitored at the Spring Creek site. The Spring Creek site had one climate station and two weighing-bucket precipitation gages (fig. 5). An electronic data logger was used with the climate station to record air temperature and relative humidity measured by a sensor; solar radiation measured by a radiometer; and wind speed, wind vector, and wind duration measured by an anemometer and a wind vane. These climatic conditions were measured at 10 -second intervals and a mean daily value was computed and stored. The Cow Camp Creek site had a single weighing-bucket precipitation gage (fig. 6). Snow depth and snow-water content were measured monthly with snow tubes at the Spring Creek, Cow Camp Creek, and soil-water control sites when snowpack was present.

Soil-water access tubes were installed at the Spring Creek, Cow Camp Creek, and soil-water control sites to measure the soil-water content in the soil profile. Soil-water access tubes were 2-in., seamlessaluminum pipe (fig. 8). A soil auger was used to auger the holes for the soil-water access tubes. Drilling in heterogeneous reclaimed spoil was difficult because of large sandstone rocks and boulders; consequently, depths of soil-water access tubes are variable. The minimum acceptable depth for each access tube was $4 \mathrm{ft}$. Soil-water content was measured in the access tubes at 1-ft intervals with a neutron probe on a monthly basis throughout the study. One-time soil dry density measurements were made at $1-\mathrm{ft}$ intervals with a density probe.

Drainage-type lysimeters were installed at a depth of $8 \mathrm{ft}$ in the reclaimed spoil at the Spring Creek and Cow Camp Creek sites. The lysimeters were installed in trenches excavated by a backhoe and then filled in with the material excavated from the trench (fig. 8). Water collected in the lysimeters drained by

Table 1. Types of instrumentation at the study sites

[Listed is number of instruments at a site; --, no instrumentation]

\begin{tabular}{|c|c|c|c|c|c|c|c|}
\hline Site & $\begin{array}{l}\text { Climate } \\
\text { statións }\end{array}$ & $\begin{array}{l}\text { Precipitation } \\
\text { gages }\end{array}$ & $\begin{array}{l}\text { Soll-water } \\
\text { access } \\
\text { tubes }\end{array}$ & Lysimeters & $\begin{array}{l}\text { Bedrock } \\
\text { wells }\end{array}$ & $\begin{array}{l}\text { Reclaimed- } \\
\text { spoil wells }\end{array}$ & $\begin{array}{c}\text { Surface- } \\
\text { water- } \\
\text { gaging } \\
\text { stations }\end{array}$ \\
\hline Spring Creek & 1 & 2 & 6 & 1 & 6 & 3 & 2 \\
\hline Cow Camp Creek & - & 1 & 5 & 1 & 4 & 4 & 2 \\
\hline Zuli & - & - & - & - & 4 & -- & - \\
\hline Bond Creek & - & - & - & - & 4 & - & - \\
\hline Soil-water control & - & - & 8 & -- & -- & - & - \\
\hline
\end{tabular}




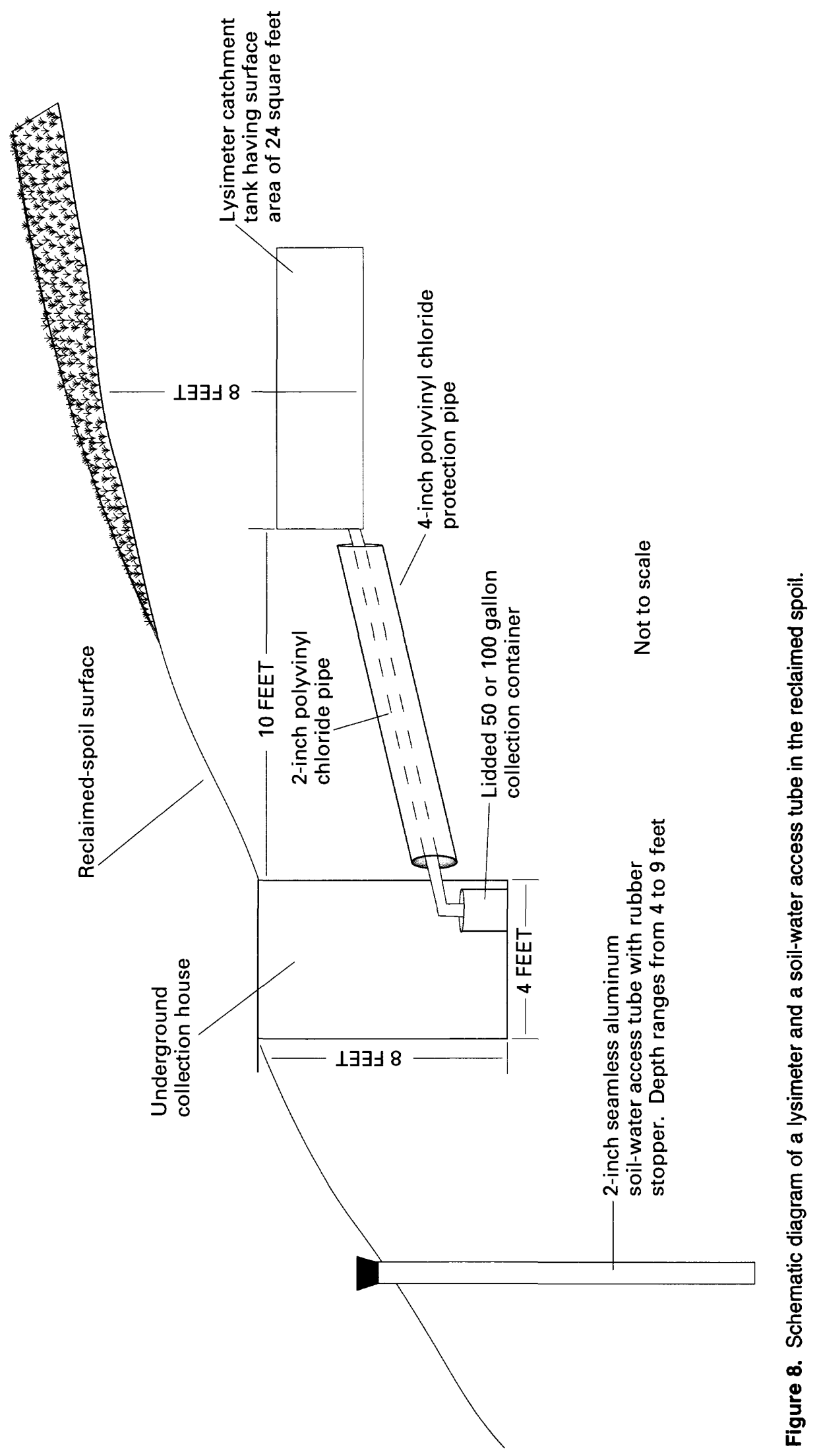


gravity to a collection container located in an underground collection house. The lysimeters were used to collect percolating water that had infiltrated below the depth of the root zone. The quantity of water collected in the lysimeters was used to estimate recharge to the reclaimed-spoil aquifer from soil water.

Eighteen bedrock and seven reclaimed-spoil wells were installed at four sites in the study area. Techniques of well installation, well completion, and well monitoring are described in a report by Williams and Clark (1992). Two sites, Spring Creek (figs. 2 and 5) and Cow Camp Creek (figs. 2 and 6), have wells completed in bedrock and reclaimed spoil. Two other sites, Zuli (figs. 2 and 5) and Bond Creek (figs. 2 and 7), have wells completed only in the bedrock.

At each of the four sites, a well was completed in the Lennox coal, the interburden (bedrock zone between the Lennox coal and the Wadge coal), the Wadge coal, and the underburden (bedrock zone below the Wadge coal). In addition, two wells completed in bedrock were drilled deeper in the underburden at the Spring Creek site, each in separate aquifers.

Seven wells completed in reclaimed spoil were installed in the study area. Three of the wells are at the Spring Creek site, and four of the wells are at the Cow Camp Creek site. Locations and names of wells (completed in bedrock or reclaimed spoil), well depths, and zones of completion are listed in table 2 .

Core samples, drill cuttings, and geophysical information were collected from the wells completed in bedrock at each of the four study sites. At each site, a continuous core sample was collected from a single well completed in bedrock, and drill cuttings were collected from those wells that were not cored. In addition, several geophysical logging techniques were used to identify and correlate lithologic features within and between the wells completed in bedrock. Geophysical and lithologic information collected at each of the wells completed in bedrock in the study area is listed in table 3.

Surface-water-gaging stations were installed at the Spring Creek and Cow Camp Creek sites to monitor discharge. A staff gage was used to indicate stage. Stage was recorded at one-half hour intervals with a punch-tape recorder installed in a shelter on a stilling well. A 90-degree "V"-notch weir was used to control flow so that discharge could be calculated. Discharge was volumetrically measured about every month using calibrated buckets.

\section{CLIMATE}

Climatic data recorded at the study area are similar to data recorded at the nearby town of Hayden. Mean annual precipitation from 1951 to 1970 at
Hayden (fig. 1), which is about $5 \mathrm{mi}$ northwest of the study area, was about 16 in. (ENMAP Corporation, 1981). The mean date of the first vegetation-killing frost is September 14, and the mean date of the last vegetation-killing frost is June 10. The mean temperature measured at the study area during water years 1988 and 1989 was about $42^{\circ} \mathrm{F}$. Temperatures during the study ranged from $-33^{\circ} \mathrm{F}$ to $95^{\circ} \mathrm{F}$ with mean daily temperatures in January and July of $18^{\circ} \mathrm{F}$ and $68^{\circ} \mathrm{F}$, respectively. Mean daily wind speed during the study was 6 to $7 \mathrm{mi} / \mathrm{h}$, and the mean relative humidity was about 56 percent. More detailed information about the climatological data collected are available in Williams and others (1992).

During the study, precipitation generally was evenly distributed throughout the year. Annual precipitation at Spring Creek was about 16 in., and annual precipitation at Cow Camp Creek was about 19 in. Because it is on the lee side of the Tow Creek anticline, the Cow Camp Creek site can receive slightly more precipitation as a result of snow redistribution. Windblown snow from the Spring Creek side of the anticline can be redeposited on the Cow Camp Creek side of the anticline.

During water years 1988 and 1989, snow accumulation at the study area began in early January. In 1988, the snow had melted by the end of February at the Spring Creek site and toward the end of March at the other sites. In 1989, the snow had melted by early March at the Spring Creek site and by the end of March at the other sites. Knowledge of the timing of snow accumulation and snowmelt helps interpret changes in soil-water content and water levels in the spoil aquifer.

Evaporation exceeds precipitation in the area. However, that does not indicate that no recharge will occur. The important factor is the timing of recharge. Most recharge occurs during a short period of time when snow is melting.

\section{HYDROLOGY}

The hydrology of the study area was characterized using ground- and surface-water data collected from the individual study sites. Ground-water data were collected from the unsaturated and saturated zones, and surface-water data were collected from streams and springs.

\section{Ground Water in the Unsaturated Zone}

Water content in the unsaturated zone was measured monthly in the reclaimed spoil at the Spring Creek and Cow Camp Creek sites and in undisturbed 
Table 2. Summary of well characteristics

[feet above NGVD, feet above National Geodetic Vertical Datum of 1929; Interburden, bedrock zone between Lennox coal and Wadge coal; Underburden, bedrock zone below Wadge coal; Rec spoil, reclaimed spoil]

\begin{tabular}{|c|c|c|c|c|c|c|}
\hline Site & $\begin{array}{c}\text { Well } \\
\text { Identification }\end{array}$ & Well name ${ }^{2}$ & $\begin{array}{l}\text { Land-surface } \\
\text { elevation } \\
\text { (feet above } \\
\text { NGVD) }\end{array}$ & $\begin{array}{l}\text { Well depth } \\
\text { (feet) }\end{array}$ & $\begin{array}{c}\text { Interval of } \\
\text { completion } \\
\text { (feet below land } \\
\text { surface) }\end{array}$ & $\begin{array}{l}\text { Zone of } \\
\text { completion }\end{array}$ \\
\hline Spring Creek & SSL287 & SL2 & 6,861 & 58 & $48-56$ & Lennox coal \\
\hline Spring Creek & SSI287 & $\mathrm{SI} 2$ & 6,860 & 80 & $56-80$ & Interburden \\
\hline Spring Creek & SSW287 & SW2 & 6,860 & 98 & $91-98$ & Wadge coal \\
\hline Spring Creek & SSU487 & SU4 & 6,861 & 105 & $95-105$ & Underburden \\
\hline Spring Creek & SSU287 & SU2 & 6,862 & 127 & $94-127$ & Underburden \\
\hline Spring Creek & SSD487 & SD4 & 6,860 & 194 & $179-193$ & Underburden \\
\hline Spring Creek & SSS487-59 & S59 & 6,899 & 33 & $6-33$ & Rec spoil \\
\hline Spring Creek & SSS487-60 & S60 & 6,893 & 23 & $3-23$ & Rec spoil \\
\hline Spring Creek & SSS487-61 & S61 & 6,892 & 26 & $7-26$ & Rec spoil \\
\hline Cow Camp & SCL287 & CL2 & 6,957 & 30 & $24-30$ & Lennox coal \\
\hline Cow Camp & SCI287 & CI2 & 6,957 & 70 & $40-70$ & Interburden \\
\hline Cow Camp & SCW287 & $\mathrm{CW} 2$ & 6,957 & 90 & $79-90$ & Wadge coal \\
\hline Cow Camp & SCU287 & CU2 & 6,957 & 122 & $103-122$ & Underburden \\
\hline Cow Camp & SCS487-62 & $\mathrm{C} 62$ & 6,976 & 52 & $4-52$ & Rec spoil \\
\hline Cow Camp & SCS487-63 & C63 & 6,983 & 38 & $7-38$ & Rec spoil \\
\hline Cow Camp & SCS487-64 & $\mathrm{C} 64$ & 6,980 & 37 & $7-37$ & Rec spoil \\
\hline Cow Camp & SCS487-65 & $\mathrm{C} 65$ & 6,997 & 25 & $7-25$ & Rec spoil \\
\hline Zuli & SZL287 & ZL2 & 6,822 & 182 & $176-182$ & Lennox coal \\
\hline Zuli & SZI287 & $\mathrm{ZI} 2$ & 6,819 & 222 & $190-222$ & Interburden \\
\hline Zuli & SZW287 & ZW2 & 6,823 & 228 & $220-228$ & Wadge coal \\
\hline Zuli & SZU287 & ZU2 & 6,820 & 265 & $251-265$ & Underburden \\
\hline Bond Creek & SBL287 & BL2 & 7,032 & 98 & $92-98$ & Lennox coal \\
\hline Bond Creek & SBI287 & $\mathrm{BI} 2$ & 7,031 & 150 & $113-150$ & Interburden \\
\hline Bond Creek & SBW287 & BW2 & 7,032 & 164 & $154-164$ & Wadge coal \\
\hline Bond Creek & SBU287 & BU2 & 7,030 & 175 & $167-175$ & Underburden \\
\hline
\end{tabular}


soil at the soil-water control site using a neutronmoisture probe. Measurements were made at $1-\mathrm{ft}$ depth intervals to the bottom of each soil-water access tube. The total depth of each soil-water access tube generally was 5 to $7 \mathrm{ft}$. The objective was to penetrate below the root zone, which was only a few feet at the study sites. Boulders and large rocks prevented drilling deeper for soil-water access tube installation. The soilwater content was measured to determine the timing of large fluxes of water through the unsaturated zone to underlying aquifers and to evaluate relative differences in soil-water content between sites.

Mean soil-porosity (fig. 9) and mean soil-water content profiles (figs. 10 to 12) from the Spring Creek, Cow Camp Creek, and soil-water control sites represent different soil conditions. Soil porosity differs between reclaimed spoil at the Spring Creek and Cow Camp Creek sites and undisturbed soils at the soil- water control site because of the difference between replacement of reclaimed spoil and natural development of undisturbed soil. Reclaimed spoil is a random assemblage of different-sized rock materials overlain by topsoil. This results in a large amount of heterogeneity in the reclaimed spoil. Consequently, porosity profiles of reclaimed spoil at the Spring Creek and Cow Camp Creek sites are variable from site to site and from depth to depth (fig. 9). A large degree of heterogeneity in the spoil material also can affect the ability of the soils to retain water in the soil profile. This can be an important factor in determining the success of revegetation of reclaimed mine sites. By contrast, undisturbed soils at the soil-water control site have undergone long-term weathering resulting in a uniform decrease in porosity with depth (fig. 9). Porosity decreases with depth because of compaction, weathering, fewer plant roots, and other physical and biological

Table 3. Summary of geophysical and lithologic logs

[C, caliper; NG, natural gamma; GG, gamma-gamma; R, resistivity; SP, spontaneous potential; N, neutron; -, no data; X, data]

\begin{tabular}{|c|c|c|c|c|c|c|c|c|}
\hline \multirow{2}{*}{ Well name ${ }^{1}$} & \multicolumn{6}{|c|}{ Geophysical logs } & \multicolumn{2}{|c|}{ Lithologic logs } \\
\hline & C & NG & GG & R & SP & $\mathbf{N}$ & Core & Cuttings \\
\hline SL2 & $\mathrm{X}$ & $\bar{X}$ & $\mathrm{X}$ & $\bar{X}$ & - & - & - & $\bar{X}$ \\
\hline $\mathrm{SI} 2$ & $\mathbf{X}$ & $X$ & $\mathrm{X}$ & $\mathbf{x}$ & - & - & - & $\mathbf{X}$ \\
\hline Sw2 & $X$ & $\mathbf{X}$ & $X$ & $\mathrm{X}$ & - & - & - & $\mathbf{X}$ \\
\hline SU4 & $\mathbf{X}$ & $\mathrm{X}$ & $\mathbf{X}$ & - & $\mathbf{x}$ & $\mathrm{X}$ & $\mathrm{X}$ & - \\
\hline SU2 & - & - & - & - & - & - & - & $X$ \\
\hline SD4 & $\mathrm{X}$ & $\mathrm{X}$ & $\mathrm{X}$ & $\mathrm{X}$ & $\mathrm{X}$ & - & - & $X$ \\
\hline CL2 & - & - & - & - & - & - & - & $\mathrm{X}$ \\
\hline $\mathrm{Cl} 2$ & $\mathrm{X}$ & $\mathrm{X}$ & $\mathbf{x}$ & $\mathrm{X}$ & $\mathrm{X}$ & - & - & $\mathrm{X}$ \\
\hline $\mathrm{CW} 2$ & $\mathbf{X}$ & $\mathrm{X}$ & $\mathrm{X}$ & $\mathrm{X}$ & $\mathrm{X}$ & - & - & $\mathrm{X}$ \\
\hline $\mathrm{CU} 2$ & $\mathrm{X}$ & $\mathrm{X}$ & $\mathrm{X}$ & $\mathrm{X}$ & $\mathrm{X}$ & - & $\mathrm{X}$ & - \\
\hline ZL2 & $\mathbf{X}$ & $\mathrm{X}$ & $\mathrm{X}$ & $\mathbf{X}$ & $\mathbf{X}$ & - & - & $\mathrm{X}$ \\
\hline $\mathrm{ZI} 2$ & $\mathrm{X}$ & $\mathrm{X}$ & $\mathrm{x}$ & $\mathrm{x}$ & $\mathrm{X}$ & - & - & $\mathrm{X}$ \\
\hline ZW2 & - & - & - & - & - & - & - & $X$ \\
\hline ZU2 & $X$ & $X$ & $X$ & $X$ & $x$ & - & $X$ & - \\
\hline BL2 & $X$ & $X$ & $X$ & $\mathrm{X}$ & $X$ & - & - & $X$ \\
\hline BI2 & $X$ & $X$ & $\mathrm{X}$ & $\mathrm{X}$ & $X$ & - & - & $X$ \\
\hline BW2 & $X$ & $X$ & $X$ & $\mathrm{X}$ & $X$ & - & - & $X$ \\
\hline BU2 & $X$ & $X$ & $X$ & $X$ & $X$ & - & $X$ & - \\
\hline
\end{tabular}




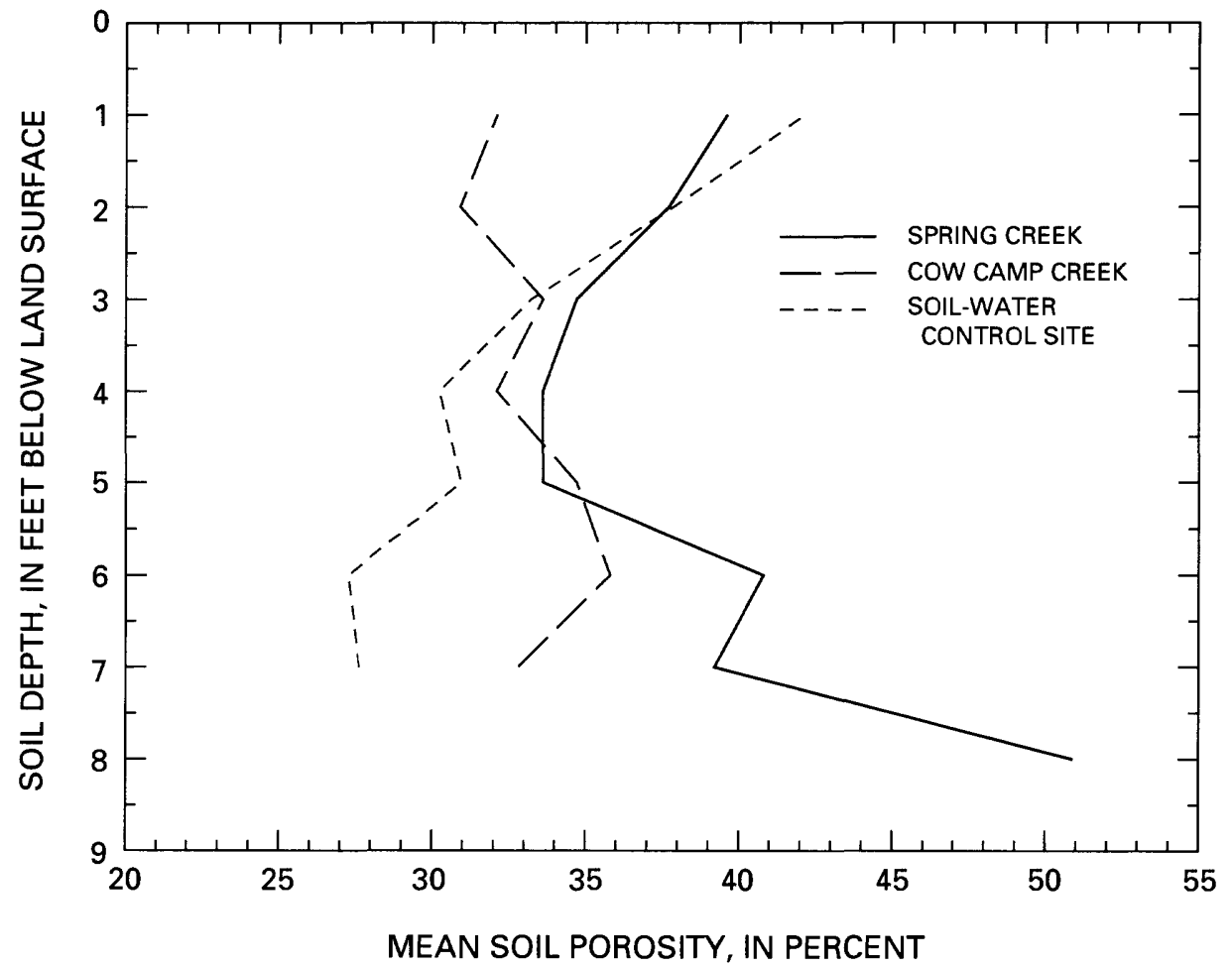

Figure 9. Mean soil-porosity profiles for the Spring Creek, Cow Camp Creek, and soil-water control sites.

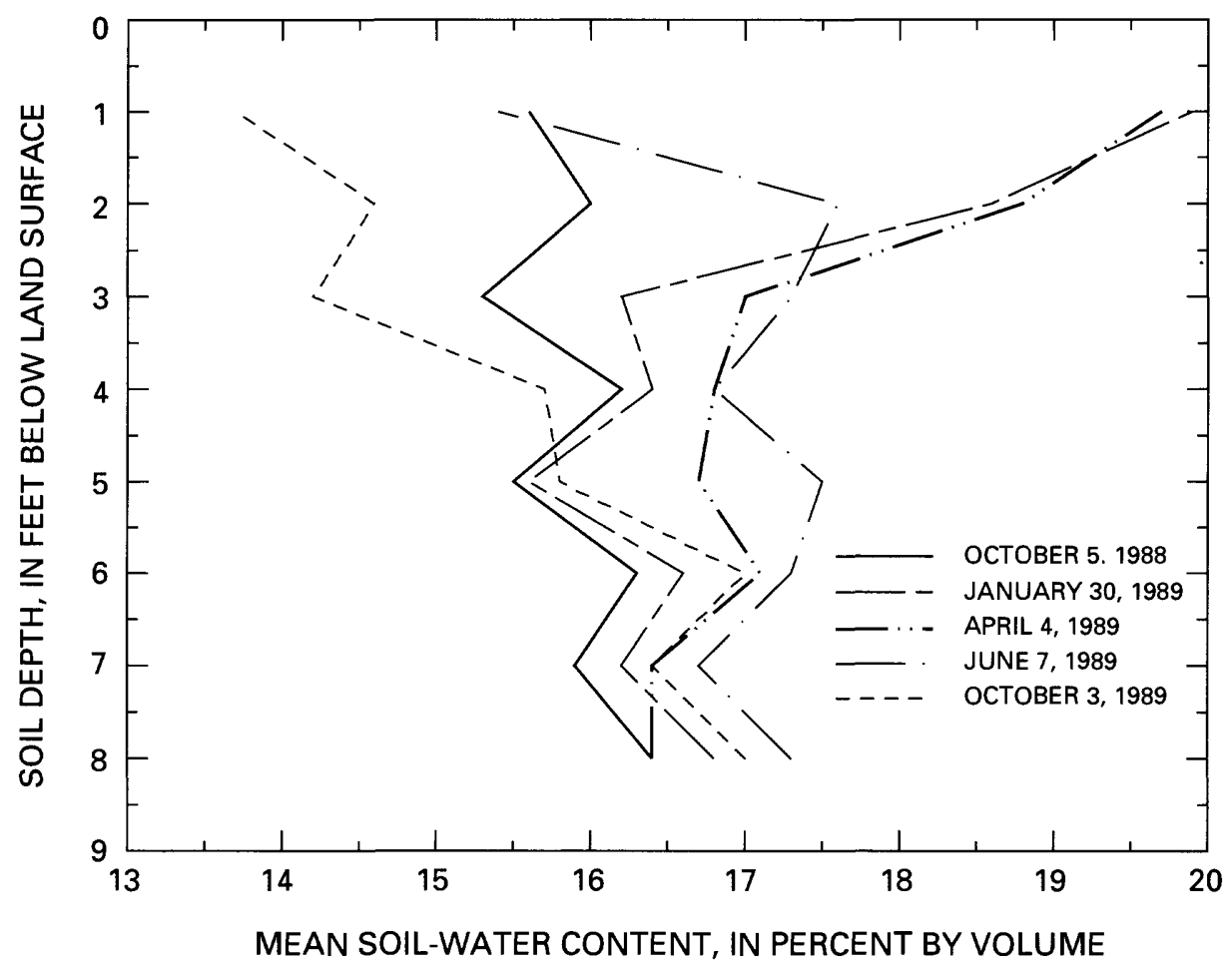

Figure 10. Selected mean soil-water content profiles at the Cow Camp Creek site. 


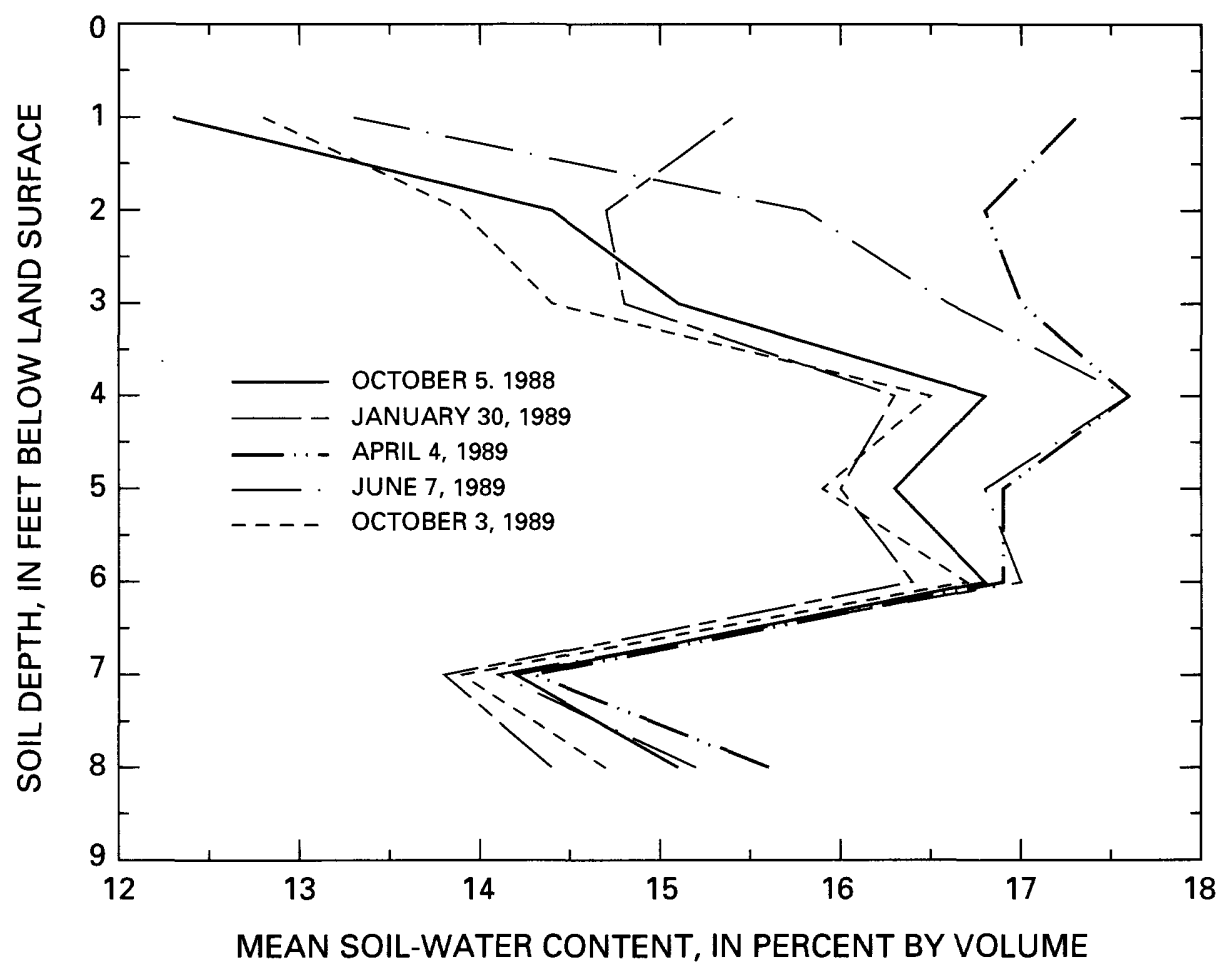

Figure 11. Selected mean soil-water content profiles at the Cow Camp Creek site.

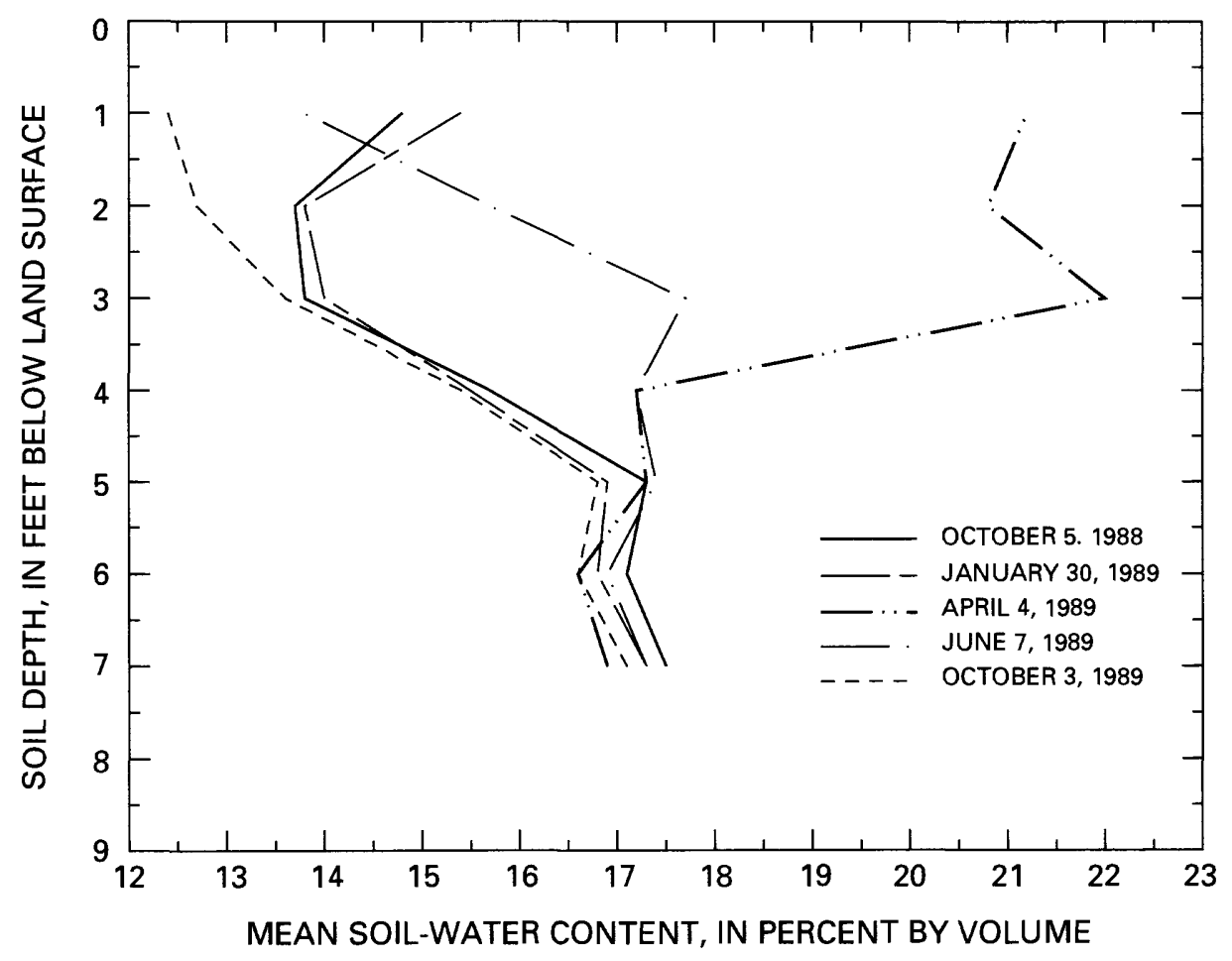

Figure 12. Selected mean soil-water content profiles at the soil-water control site. 
factors. Undisturbed soils probably also retain more soil water than soils at reclaimed sites because of a greater quantity of fine-grained materials.

Differences in porosity affect the way water moves through the reclaimed spoil or the undisturbed soil profile. The profiles represent the mean soil-water content for all of the soil-water access tubes at a site for a given date. Soil-water content begins to increase at the shallower depths as early as January when snow first begins to melt. This is especially apparent at the Spring Creek site where the onset of snowmelt occurs the earliest. As spring snowmelt continues, deeper portions in the soil profile begin to show an increase in soil-water content. The near surface soil-water content begins to decrease following snowmelt and continues to decrease during the summer and early fall. The deeper zones of the soil profile do not change as substantially in response to snowmelt as do the shallower zones of the profile. Comparison of the October 1988 and October 1989 profiles indicates that the soilwater content can vary from year to year, and thus, antecedent conditions prior to snowmelt can vary.

Topographic features at the study sites seem to affect the timing of snowmelt. Snow melts at the Spring Creek site sooner than at the Cow Camp Creek and soil-water control sites. As the snow melts and infiltrates the soil, the mean soil-water content over the depth interval of $0-7 \mathrm{ft}$ at all of the sites begins to increase (fig. 13). The Spring Creek snowpack melts first because it has a westerly aspect that allows solar radiation to warm slopes much of the day. At the Cow Camp Creek site, total snowmelt occurs later than at the Spring Creek site because Cow Camp Creek is in a small valley with a southeasterly aspect. The valley retains the cold night air and is shaded to the east by a valley wall; consequently, snow melts at a later date than at Spring Creek.

The soil-water control site has a slope and aspect similar to the Spring Creek site, but snow melts similarly to Cow Camp Creek. The major difference between Spring Creek and the soil-water control site is the maturity of the vegetation. The soil-water control site has a well-established community of shrubs that shelter the snowpack from radiation and thus delay snowmelt. The Spring Creek site is still in the early stages of reestablishment of vegetation, and during the study period the site primarily was composed of grasses and bare slopes.

The timing of snowmelt affects the movement of water into and through the reclaimed spoil and undisturbed soil. Differences in the soil-water content through the year in reclaimed spoil at the Spring Creek and Cow Camp Creek sites and the undisturbed soils at the soil-water control site can be seen in figure 13. The
Spring Creek site shows a consistent gain in soil-water content before the other two sites show much gain. Although the earlier increase in the soil-water content at Spring Creek probably is due to an earlier onset of snowmelt, differences in porosity and permeability of the soils also can affect the timing of soil-water movement. The decreasing trend in soil-water content through the summer and fall is similar for the reclaimed-spoil sites. By contrast, more total soil water is lost from the soil-water control site than at the reclaimed-spoil sites. The greater loss can be due to ongoing consumptive use of the soil water by the established, mature vegetation at the soil-water control site. Because mature plant communities are not reestablished at the reclaimed-spoil sites, soil water remains near field capacity throughout the year ( 3 or $4 \mathrm{ft}$ below land surface). The available soil water (the amount of water between field capacity and the wilting point) is used by plants during the growing season at the soilwater control site.

Installing soil-water access tubes by drilling can be difficult. Augering in the reclaimed spoil is difficult because of the heterogeneity of the material. The soil auger used could not drill through sandstone boulders. A larger drill rig could not be used because of the inaccessibility of the site. Consequently, soil-water access tubes were installed where drilling was possible.

Calibration of the neutron probe for water content in a reclaimed spoil is extremely difficult. Gravimetric analysis is the primary method by which a neutron probe is calibrated. However, because of the heterogeneity of the spoil material, obtaining core samples for gravimetric analysis of reclaimed spoil is very difficult. Therefore, the soil-water contents measured in this study were used to indicate relative changes in soil-water content rather than absolute values for the soil-water content.

Gravity-fed lysimeters were used to quantify deep percolation of soil water below the depth of the root zone and to collect samples for water-quality analysis. Because the lysimeters were about $8 \mathrm{ft}$ deep, it was assumed that water collected in the lysimeters represents water that has passed below the depth of plant roots and will eventually recharge the reclaimed-spoil aquifer.

The quantity of water recharging the spoil aquifers from percolation of soil water was calculated by dividing the volume of water collected in the lysimeter collection container by the catchment area of the lysimeter. This calculation indicated that at the Cow Camp Creek site about 3.4 in. of water were recharged to the reclaimed-spoil aquifer during water year 1988. This recharge value is similar to other values obtained for aquifer recharge through reclaimed spoil (Williams and 


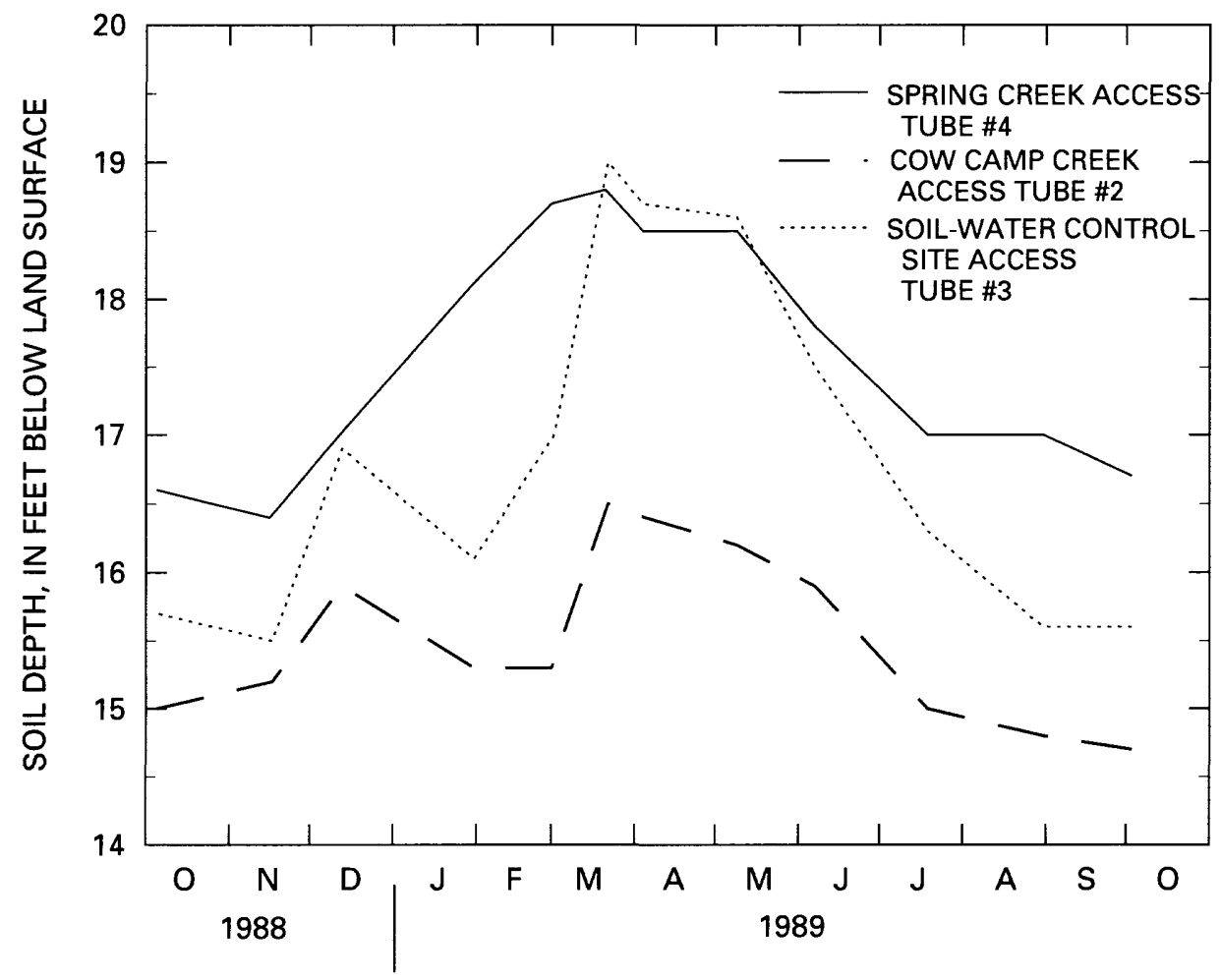

Figure 13. Mean soil-water content for depth intervals of 0 to 7 feet at selected soil-water access tubes at the Spring Creek, Cow Camp Creek, and soil-water control sites, October 1988-October 1989.

Hammond, 1988). Three inches of recharge from snowmelt was used for mass-balance modeling at a nearby mine (Day and others, 1987).

At the Spring Creek site, most of the snow melted within a few days. This resulted in a recharge rate that was too rapid for the capacity of the lysimeter. Consequently, the collection container overflowed, and the quantity of recharge through the reclaimed spoil at Spring Creek could not be calculated. At the Cow Camp Creek site, snowmelt occurred over a longer period of time, and the problem of an overflowing collection container was not encountered.

\section{Ground Water in the Saturated Zone}

The occurrence of water in the reclaimed-spoil aquifers and bedrock aquifers and the hydraulic characteristics of those aquifers were determined by various methods utilizing wells installed as part of this study. Well-drilling, well-completion, and well-development techniques used have been described in several publications (Campbell and Lehr, 1973; U.S. Bureau of Rec- lamation, 1977; Freeze and Cherry, 1979; Barcelona and others, 1985; Driscoll, 1986; Aller and others, 1989; Williams and Clark, 1992). A primary concern in this study was to complete each well in only one aquifer. To achieve this aquifer isolation, core-drilling and rotary-drilling techniques were used to drill the bedrock wells. Geophysical logs were used to identify specific lithologic zones and confirm lithologic information obtained during drilling.

\section{Reclaimed-Spoil Aquifers}

Wells were completed in the reclaimed-spoil aquifers at the Spring Creek and Cow Camp Creek sites. One well at Spring Creek (S61) and one well at Cow Camp Creek (C63) were equipped with recorders to monitor water-level fluctuations in the aquifers during water year 1989. Hydrographs of instantaneous water-level measurements from December 1987 to October 1989 for the reclaimed-spoil wells at the sites are shown in figures 14 and 15. One well (SCS487-65) remained dry during the entire study and is not plotted on figure 15. Both reclaimed-spoil aquifers had a rapid 


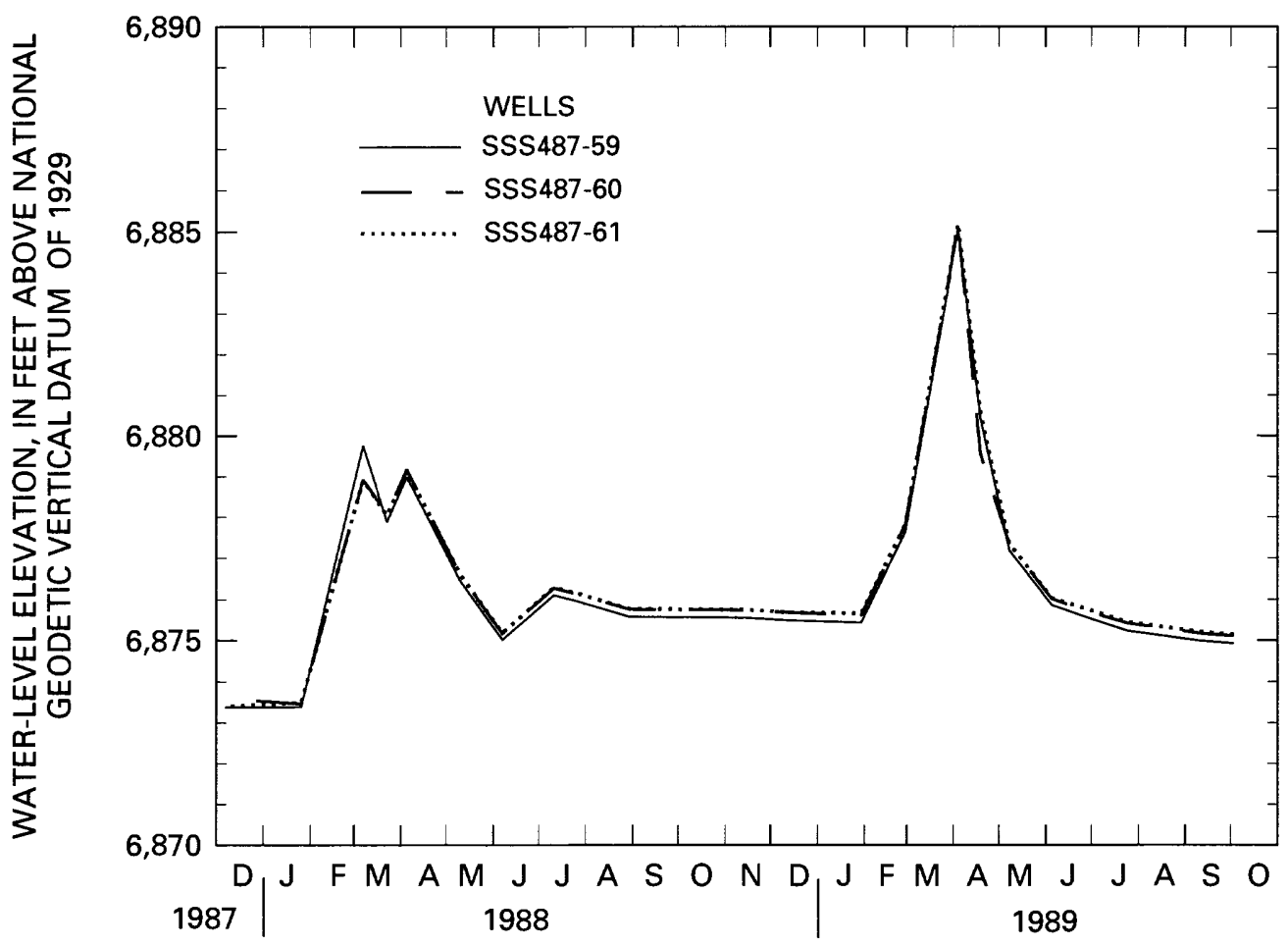

Figure 14. Instantaneous water levels for selected wells completed in reclaimed spoil at the Spring Creek site, December 1987-October 1989.

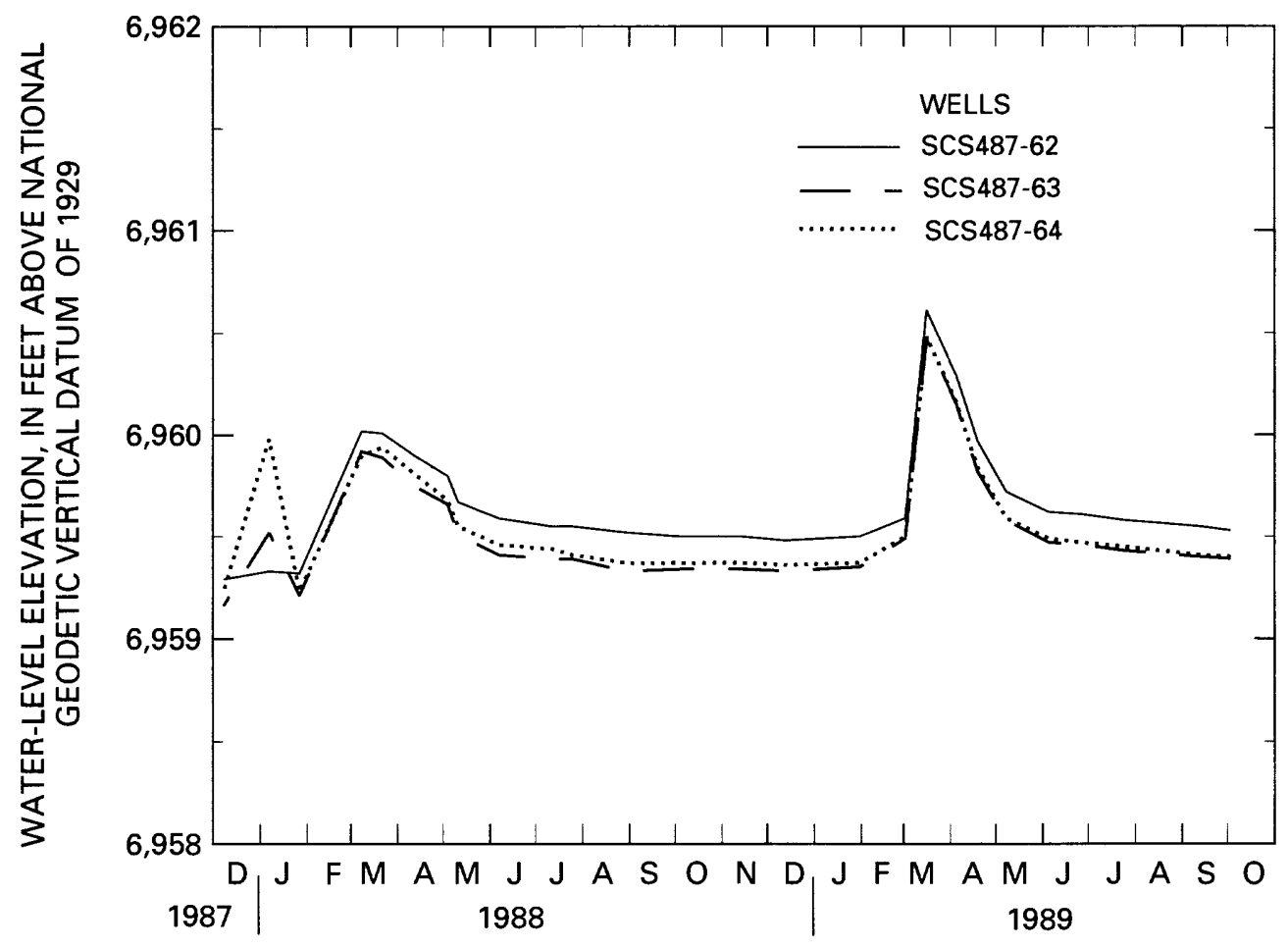

Figure 15. Instantaneous water levels for selected wells completed in reclaimed spoil at the Cow Camp Creek site, December 1987-October 1989. 
rise in water level in the spring as a result of snowmelt percolating to the water table. Individual rain storms during the summer seem to have little if any effect on the aquifers. Most of the summer rain probably is lost by evapotranspiration and is assumed to have no effect on ground-water recharge.

Drilling wells in reclaimed spoil presents some problems. A rotary drilling rig can drill through the reclaimed spoil easily; however, keeping the borehole from collapsing prior to well completion is difficult. An auger rig was used to drill the wells in the reclaimed spoil because the auger flights can be left in place, which prevents collapse of the borehole during well completion. Use of a casing advancer while drilling is another technique for installing wells in reclaimed spoil. This technique combines the rapid drilling ability of rotary methods with the option to leave casing in the bore hole during well completion.

To install wells in the reclaimed-spoil aquifer, the areal extent of the aquifer needs to be determined. Initial drilling-site selections were based on maps from the mine plan, which are completed prior to mining. However, mine-plan maps do not always coincide exactly with what actually occurs during mining. Consequently, it may be difficult to locate an aquifer that has limited areal extent, such as at Spring Creek where a number of dry wells were drilled prior to locating the aquifer.

Determining the depth of the reclaimed spoil also can present problems. Spoil is replaced to the approximate original contour of the area before mining. However, the elevation of the reclaimed-spoil surface can be several feet different than the original land surface; this prevents an easy calculation of the total depth of the reclaimed spoil. During mining, large sandstone boulders roll to the mine pit floor. These large boulders can be located throughout the reclaimed spoil. During drilling, it can be difficult to determine if the auger rig has come in contact with one or several of the boulders or if the mine pit floor has been reached. The large sandstone boulders also can prevent deeper drilling with an auger rig, and a new drilling site might need to be selected.

\section{Bedrock Aquifers}

All of the bedrock aquifers in which groundwater wells were completed during this study were under confined or semiconfined conditions. Water levels in all wells completed in a bedrock aquifer were above land surface. Hydrographs showing water levels for the wells completed in bedrock at Spring Creek, Cow Camp Creek, Zuli, and Bond Creek are shown in figures 16 through 19.
In general, water levels in the wells completed in bedrock aquifers in the study area increase with depth. This relation indicates the potential for water to move from deeper to shallower bedrock aquifers and potentially to reclaimed-spoil aquifers. Because the aquifers are confined or semiconfined and are relatively impermeable if undisturbed, an avenue for upward flow must be present to facilitate a large amount of water movement between aquifers. Emrich and Merritt (1969) concluded that joints, fractures, and abandoned oil and gas wells are features that can provide a means for vertical hydraulic connection within coal-mine areas. In the study area and other areas, several possible natural and man-induced features could provide a means of flow. Natural features can include faults and fractures that exist in the area. Man-induced features can include abandoned boreholes that could provide a conduit for flow (abandoned boreholes are not known to be a factor at the study area) and secondary permeability in confining layers resulting from blasting and removal of overburden and operation of heavy equipment in the mine pit.

The flowing wells in the bedrock were successfully closed during December 1987 and did not seem to fully recover their hydraulic head until the first few months of 1988. The recovery was slow in part because the wells flowed continuously during drilling, and because of well development and well completion. The slow recovery in water levels following an extended period of flow indicates that if wells at a site are opened and allowed to flow, the aquifers might not recover for several months following closure, and measurements of levels made during this recovery period could underestimate the true water levels of an aquifer. This could potentially lead to erroneous interpretations of mine-site hydrology.

Measurement of water levels in flowing wells can be difficult during the winter. Because the water level is above land surface, water is present at the top of the polyvinylchloride (PVC) well casing. If the water in the well freezes, the well casing can break. Consequently, two different techniques were used for measuring hydraulic head in flowing wells during the winter and summer. During winter, water levels in the flowing wells were pressurized with nitrogen to a level below the frost depth. Water levels were then measured by attaching a pressure gage to a sinker line with an orifice opening located at $50 \mathrm{ft}$ below the land surface. By clearing the sinker line with nitrogen and recording the amount of backpressure on the gage, a water level was obtained by converting hydrostatic pressure to feet of water. During summer, when freezing wells were not a concern, water was allowed to rise up into the sinker line, and direct gage-pressure read- 


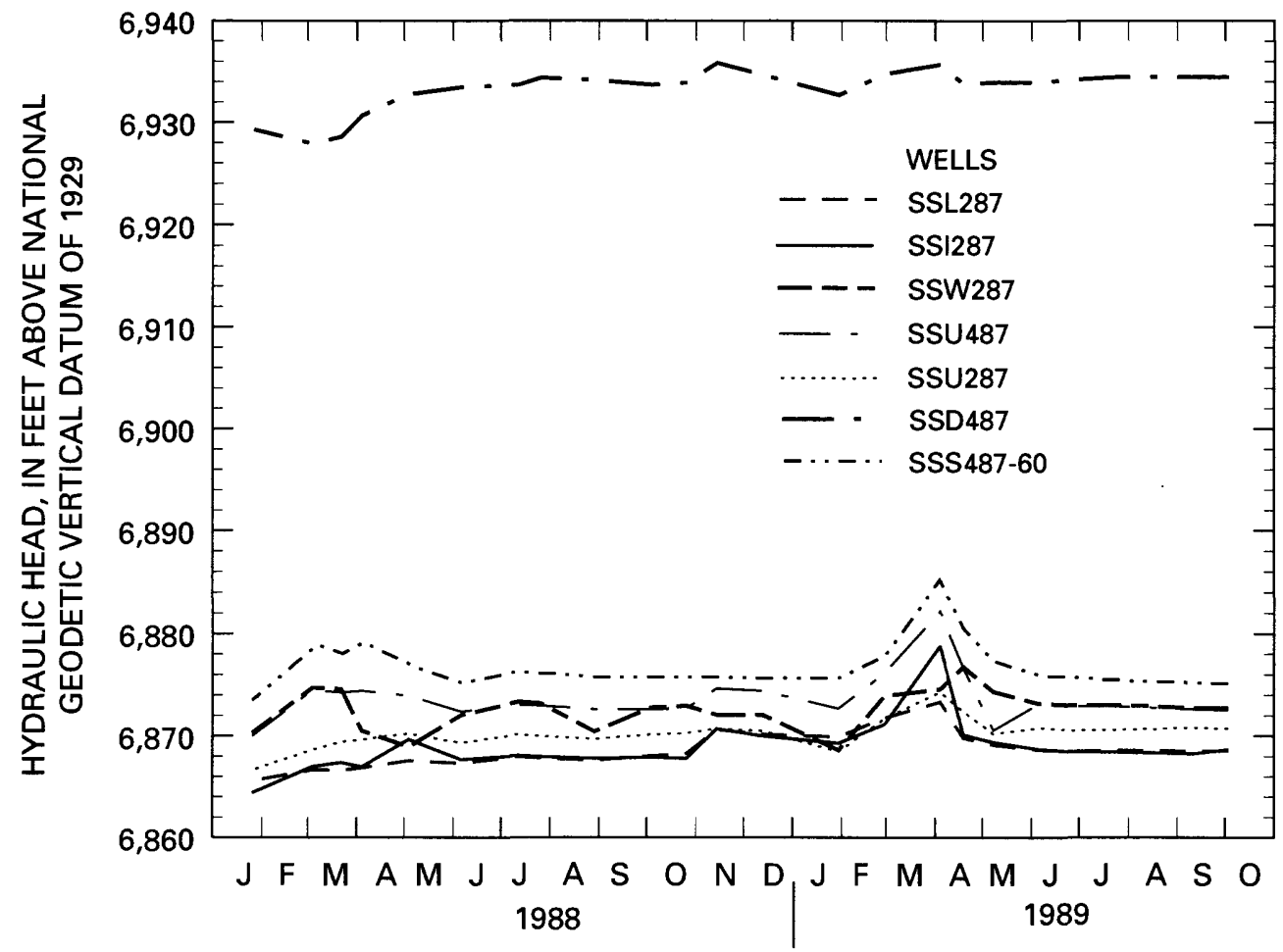

Figure 16. Instantaneous hydraulic head for wells completed in bedrock and the water level for one well completed in reclaimed spoil at the Spring Creok site, January 1988October 1989.

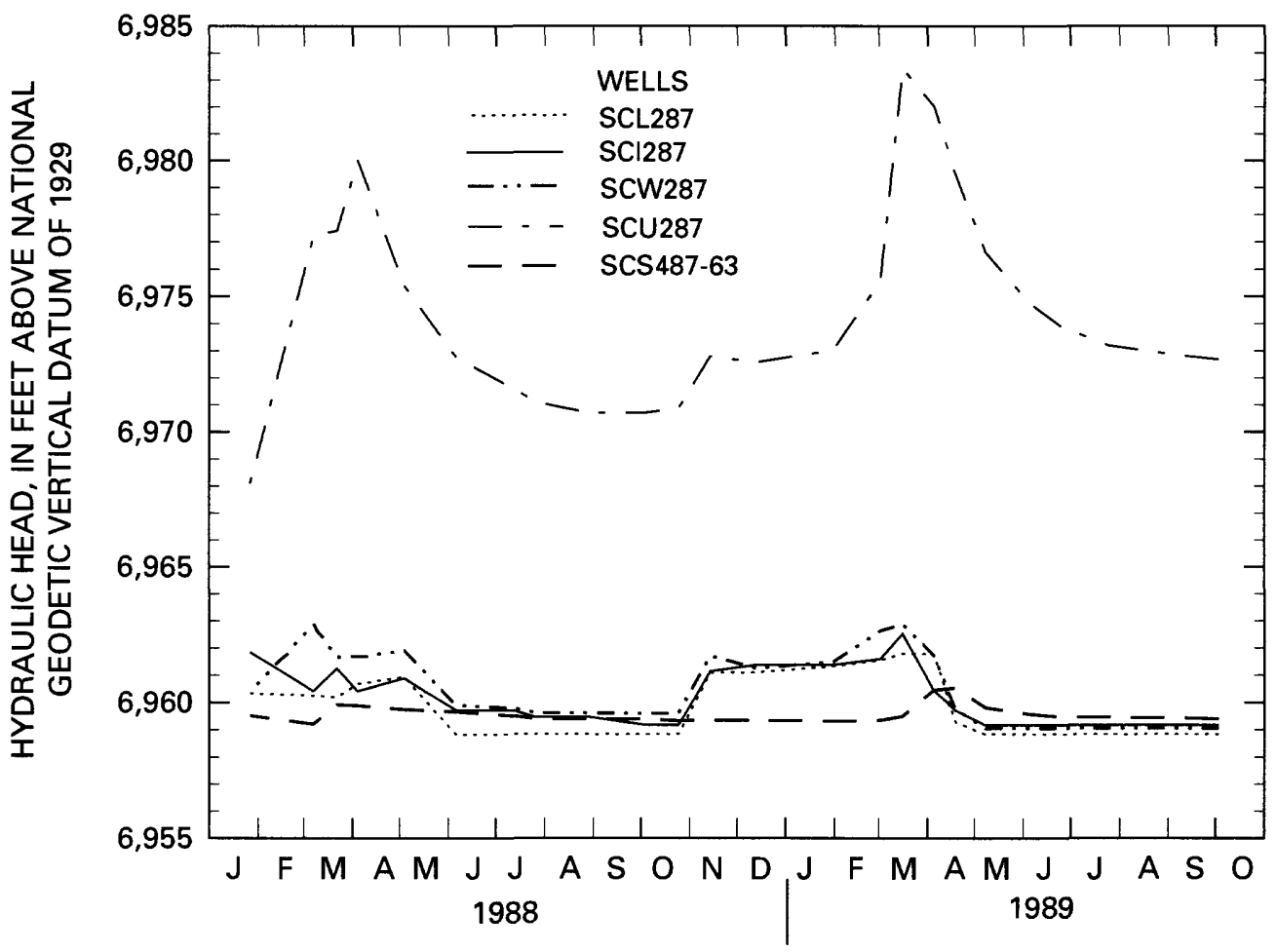

Figure 17. Instantaneous hydraulic head for wells completed in bedrock and the water level for one well completed in reclaimed spoil at the Cow Camp Creek site, January 1988October 1989. 


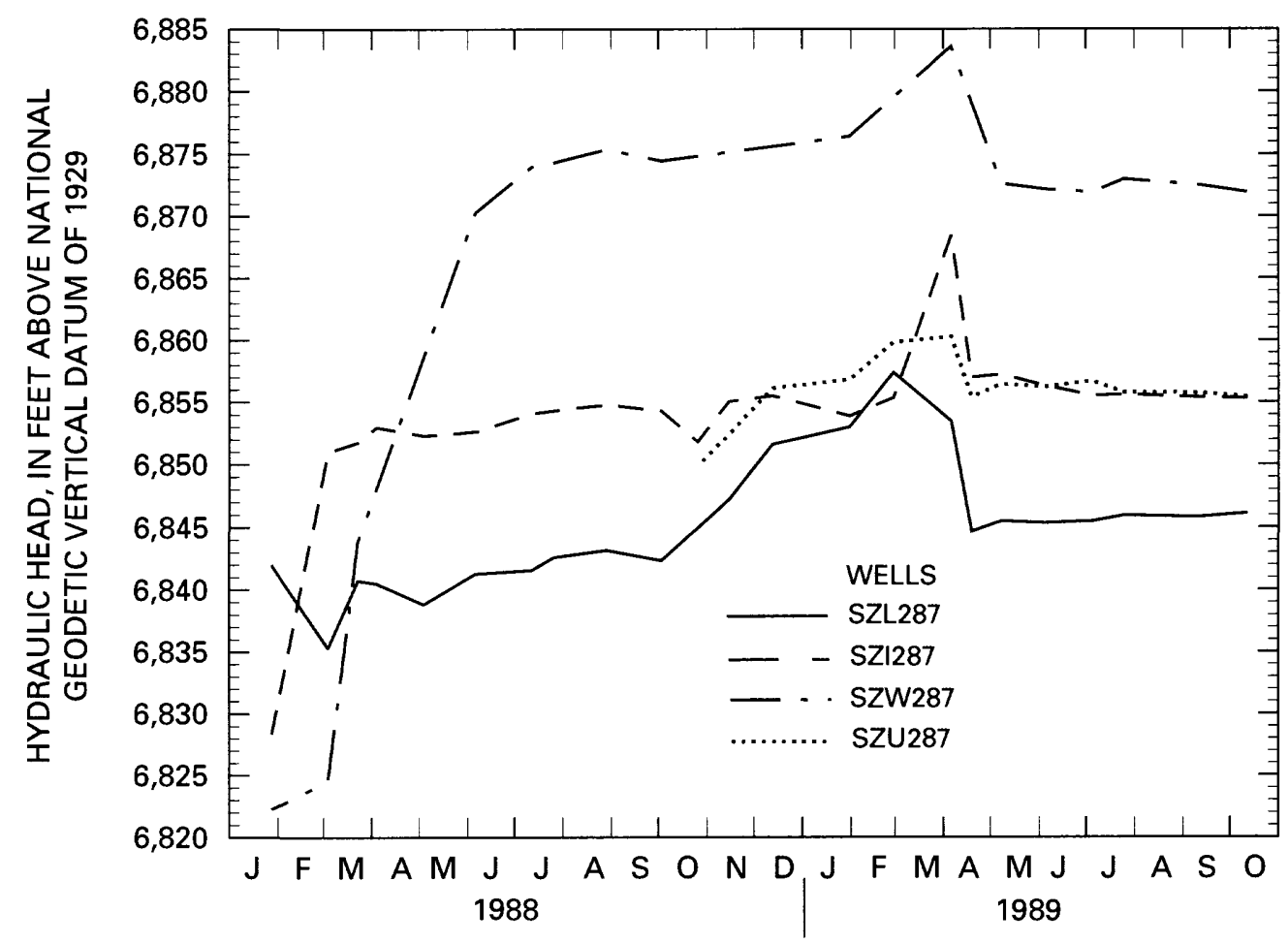

Figure 18. Instantaneous hydraulic head for wells completed in bedrock at the Zuli site, January 1988-October 1989.

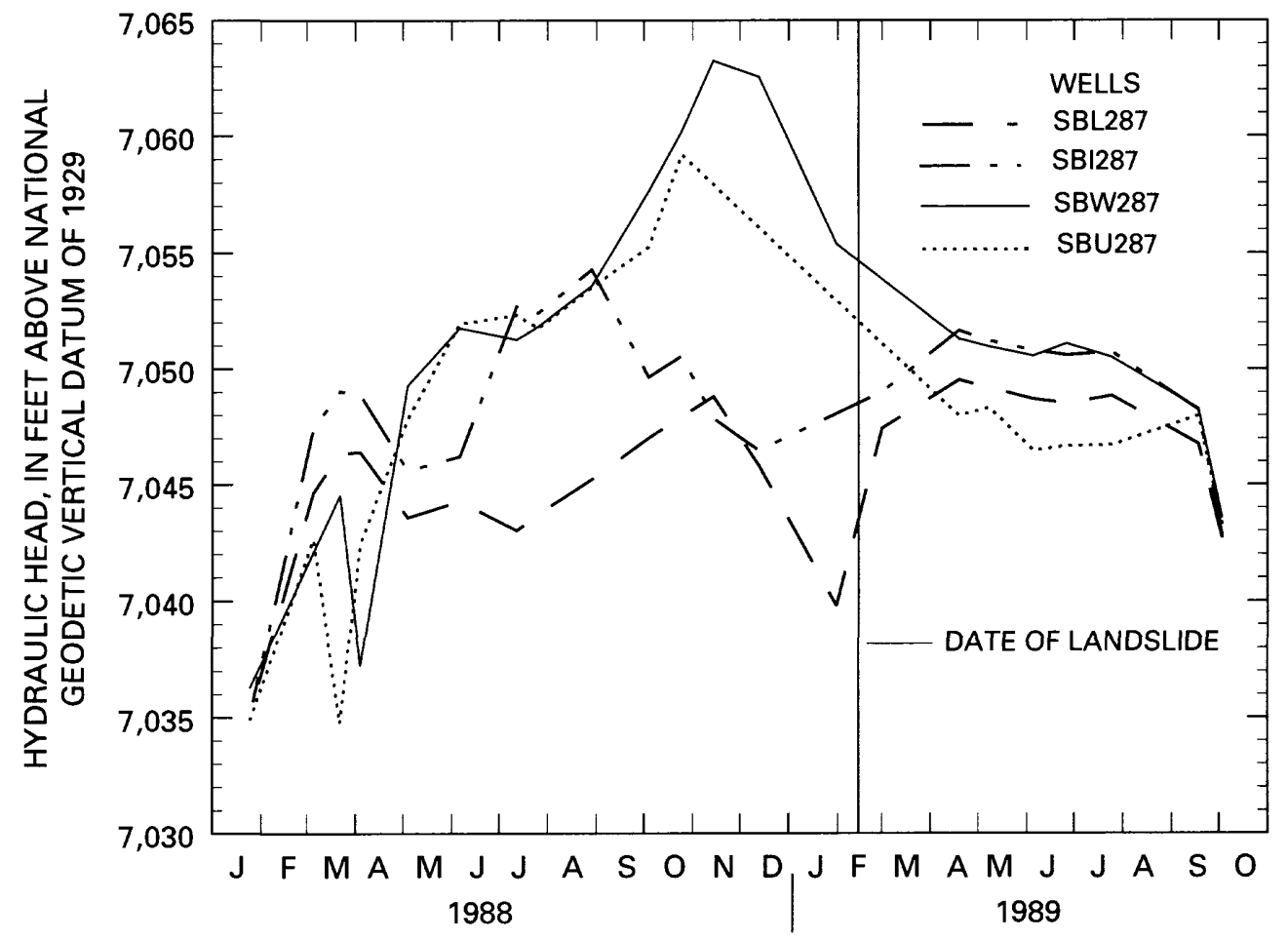

Figure 19. Instantaneous hydraulic head for wells completed in bedrock at the Bond Creek site, January 1988-October 1989. 
ings could be obtained. A more detailed discussion of methods of water-level measurements used in this study are available in Williams and Clark (1992). Although the winter and summer measurement techniques did not agree exactly when comparisons were made, data obtained from both are included in the hydrographs because trends are still evident.

\section{Aquifer Hydraulic Properties}

Aquifer tests were conducted for the reclaimedspoil aquifers at Spring Creek and Cow Camp Creek using one reclaimed-spoil well at each site and for each well completed in bedrock at all four of the study sites. Five types of aquifer tests were used to evaluate aquifer hydraulic properties. The five types were pumping tests, flowing-well tests, recovery tests, slug tests, and pressure-slug tests. Descriptions of each type of aquifer test and the equipment used for the test are discussed in Williams and Clark (1992).

To test unconfined reclaimed-spoil aquifers, aquifer tests were used. The reclaimed-spoil aquifers were bounded by nearby structural features. Examples of these features are the low wall and the side walls of the mine pit, which might function as impermeable or semipermeable boundaries if unfractured shales or clays are present. Upward leakage through the floor of the mine pit from underlying aquifers can result in a leaky boundary condition. The effect of these features on an aquifer test can be minor. The occurrence, extent, and effect of faults and fractures, which commonly are present in bedrock near the unconfined reclaimed-spoil aquifer, are difficult to determine. However, faults and fractures generally increase porosity and permeability (Davis and DeWiest, 1966). For most reclaimed-spoil settings, estimating the aquifer hydraulic properties within an order of magnitude or more might be sufficient.

To test confined bedrock aquifers, flowing-well tests, recovery tests, slug tests, and pressure-slug tests were used. A flowing-well test was used for wells that had a sufficient volume of flow to permit easy measurement of discharge. Recovery tests were used to verify results from selected flowing-well tests. A slug test was used for confined bedrock aquifers where the water level in the well was above land surface but below the top of the well casing. The pressure-slug test was used for confined bedrock aquifers that did not produce enough discharge to be easily measured, yet had water levels above the top of the well casing.

Results indicate that the hydraulic conductivity of the reclaimed-spoil aquifers generally is much larger than for the bedrock aquifers (table 4). The larger values in the reclaimed-spoil aquifer probably are a result of the lack of consolidation in the sporl as compared to bedrock. One bedrock aquifer, the Lennox coal at the Cow Camp Creek site, had a hydraulic conductivity that seemed to be enhanced by fracturing in the coal seam.

The difference in hydraulic conductivity between the reclaimed-spoil aquifers and the bedrock aquifers has a significant hydrologic consequence. Because the volume of water recharged to the spoil aquifers is larger than the volume of water that can be transmitted through the bedrock system under existing conditions, water levels in the reclaimed spoil near the low wall begin to rise. Eventually, the water level in the reclaimed-spoil aquifer could rise to land surface, and a spring could form. The springs monitored in this study flowed throughout the study period. Prior to mining, streams draining the study area were ephemeral or intermittent. Since mining, the streams have become perennial, largely as a result of the flow from these springs. The development of perennial flow can be significant in a semiarid environment such as northwestern Colorado.

\section{Core Hydraulic Properties}

Porosity, grain density, and permeability analyses were done on fifty-four 1-in.-diameter samples extracted from 4 5/8-in.-diameter core collected from the study sites (table 5). Selected samples were drilled perpendicular to the core axis (horizontal orientation), while others were drilled parallel to the core axis (vertical orientation). Permeability tests were done on the samples by using helium injection to determine permeability to gas. The results can be slippage-corrected to an equivalent permeability of a nonreactive liquid (Klinkenberg, 1941). In addition, selected samples were tested for their hydraulic conductivity to water.

A linear relation was derived between permeability to air and hydraulic conductivity in 11 sandstone core samples (fig. 20) and was used to estimate the hydraulic conductivity in the other 21 sandstone core samples. Hydraulic-conductivity values measured in the sandstone samples were all less than the permeability for a nonreactive liquid that would represent the theoretical maximum. This probably results from an abundance of clay minerals present in the sandstones which, upon wetting, expand to impede flow through the sample matrix. A relation between permeability to air and hydraulic conductivity could not be established for the coal and shale samples because of a combination of extremely small hydraulic-conductivity values and the physical breakdown of a number of the samples during testing. 
Table 4. Selected hydraulic-conductivity values calculated from aquifer tests and core tests $[-$, no wells; --, no data $]$

\begin{tabular}{lcccc}
\hline \multirow{2}{*}{ Lithologic unit } & \multicolumn{3}{c}{ Hydraulic-conductivity values determined from aquifer tests, in feet per day } \\
\cline { 2 - 5 } & Spring Creek & Cow Camp Creek & Zull & Bond Creek \\
\hline Lennox coal & $6 \times 10^{-1}$ & $8 \times 10^{-1}$ & $7 \times 10^{-2}$ & $3 \times 10^{-2}$ \\
Interburden & $2 \times 10^{-1}$ & $1 \times 10^{-1}$ & $3 \times 10^{-2}$ & $5 \times 10^{0}$ \\
Wadge coal & $9 \times 10^{-1}$ & $1 \times 10^{0}$ & $3 \times 10^{-1}$ & $2 \times 10^{-3}$ \\
Underburden & $6 \times 10^{-1}$ & $8 \times 10^{0}$ & $6 \times 10^{-5}$ & $1 \times 10^{-3}$ \\
Reclaimed spoil & $5 \times 10^{2}$ & $6 \times 10^{1}$ & - & - \\
& & & & \\
\hline \hline
\end{tabular}

\begin{tabular}{|c|c|c|c|c|}
\hline \multirow{2}{*}{ Lithologic unit } & \multicolumn{4}{|c|}{ Hydraulic-conductivity values determined from core tests, in feet per day } \\
\hline & Spring Creek & Cow Camp Creek & Zull & Bond Creek \\
\hline Lennox coal & $<2.1 \times 10^{-6}$ & -- & $2.1 \times 10^{-6}$ & $<2 \times 10^{-6}$ \\
\hline Interburden & $9.1 \times 10^{-4}$ & $2.7 \times 10^{-3}$ & $1.7 \times 10^{-2}$ & $1.8 \times 10^{-3}$ \\
\hline Wadge coal & -- & -- & $<2.1 \times 10^{-6}$ & -- \\
\hline Underburden & $1.9 \times 10^{-5}$ & $4.2 \times 10^{-5}$ & $<2.1 \times 10^{-6}$ & $6.6 \times 10^{-4}$ \\
\hline
\end{tabular}

Table 5. Porosity, grain density, permeability to air, and hydraulic conductivity of selected core samples collected from the study area

[Sample identifications were designated as follows: The first letter of the identification corresponds to the site location, $S$ indicating the Spring Creek site (well name, SU4), C the Cow Camp Creek site (well name, CU2), B the Bond Creek site (well name, BU2), and Z the Zuli site (well name, ZU2). The numeral represents the relative depth of the sample at each site, 1 being the shallowest. The last letter in the identification indicates the orientation of the sample, $\mathrm{V}$ being vertically oriented and $\mathrm{H}$ being horizontally oriented; $\mathrm{g} / \mathrm{cm}^{3}$, gram per cubic centimeter; $\mathrm{mD}$, millidarcy; ft/d, foot per day; ---, was not or could not be measured or calculated; $c$, calculated value; $m$, measured value; $<$, less than]

\begin{tabular}{|c|c|c|c|c|c|c|}
\hline $\begin{array}{c}\text { Sample } \\
\text { identiflcation }\end{array}$ & $\begin{array}{l}\text { Depth of } \\
\text { sample } \\
\text { (fi) }\end{array}$ & Llthologic type & $\begin{array}{l}\text { Porosity } \\
\text { (percent) }\end{array}$ & $\begin{array}{l}\text { Grain density } \\
\left(9 / \mathrm{cm}^{3}\right)\end{array}$ & $\begin{array}{l}\text { Permeability to } \\
\text { air } \\
\text { (mD) }\end{array}$ & $\begin{array}{c}\text { Hydraulic } \\
\text { conductivity' } \\
\text { (ft/d) }\end{array}$ \\
\hline S1V & $35.1-35.4$ & Shale & 3.6 & 2.50 & -- & --- \\
\hline $\mathrm{S} 2 \mathrm{~V}$ & $37.1-37.7$ & Sandstone & 9.6 & 2.67 & 11.1 & $7.1 \times 10^{-3} \mathrm{c}$ \\
\hline S3H & $41.1-41.6$ & Lennox coal & 7.1 & 1.35 & 2.37 & $<2.1 \times 10^{-6} \mathrm{~m}$ \\
\hline S4V & $48.5-49.0$ & Shale & 5.6 & 2.64 & .016 & -- \\
\hline S5H & $60.6-61.1$ & Sandstone & 16.7 & 2.67 & 2.02 & $9.1 \times 10^{-4} \mathrm{~m}$ \\
\hline S5V & $60.6-61.1$ & Sandstone & 17.7 & 2.65 & 5.84 & $3.0 \times 10^{-3} \mathrm{c}$ \\
\hline $\mathrm{S} 6 \mathrm{H}$ & $75.0-75.5$ & Sandstone & 15.2 & 2.66 & 7.32 & $4.1 \times 10^{-3} \mathrm{c}$ \\
\hline $\mathrm{S} 8 \mathrm{H}$ & $86.5-86.9$ & Wadge coal & 6.7 & 1.34 & --- &.-- \\
\hline S10V & $94.4-94.7$ & Shale & 6.2 & 2.40 & $<.01$ & --- \\
\hline S11H & $100.0-100.5$ & Sandstone & 10.8 & 2.67 & .149 & $1.9 \times 10^{-5} \mathrm{~m}$ \\
\hline $\mathrm{S} 12 \mathrm{H}$ & $102.1-102.6$ & Sandstone & 8.1 & 2.64 & .011 & $7.0 \times 10^{-7} \mathrm{~m}$ \\
\hline $\mathrm{C} 1 \mathrm{~V}$ & $18.4-19.0$ & Sandstone & 9.8 & 2.63 & 0.105 & $1.4 \times 10^{-5} \mathrm{c}$ \\
\hline $\mathrm{C} 2 \mathrm{H}$ & $22.3-22.9$ & Lennox coal & 6.2 & 1.38 & 1.76 & -- \\
\hline $\mathrm{C} 3 \mathrm{~V}$ & $27.7-28.2$ & Sandstone & 11.2 & 2.67 & .027 & $2.2 \times 10^{-6} \mathrm{c}$ \\
\hline $\mathrm{C} 4 \mathrm{H}$ & $29.8-30.2$ & Sandstone & 9.2 & 2.64 & 46.5 & $4.8 \times 10^{-2} c$ \\
\hline $\mathrm{C} 6 \mathrm{H}$ & $44.8-45.3$ & Sandstone & 16.7 & 2.66 & 4.59 & $2.7 \times 10^{-3} \mathrm{~m}$ \\
\hline $\mathrm{C} 7 \mathrm{H}$ & $55.0-55.5$ & Sandstone & 15.4 & 2.66 & 1.75 & $5.9 \times 10^{-4} c$ \\
\hline $\mathrm{C} 7 \mathrm{~V}$ & $55.0-55.5$ & Sandstone & 15.4 & 2.64 & .839 & $2.2 \times 10^{-4} \mathrm{c}$ \\
\hline $\mathrm{C} 9 \mathrm{H}$ & $66.0-66.5$ & Sandstone & 15.7 & 2.66 & 7.71 & $3.3 \times 10^{-3} \mathrm{~m}$ \\
\hline
\end{tabular}


Table 5. Porosity, grain density, permeability to air, and hydraulic conductivity of selected core samples collected from the study area--Continued

\begin{tabular}{|c|c|c|c|c|c|c|}
\hline $\begin{array}{c}\text { Sample } \\
\text { Identiflcation }\end{array}$ & $\begin{array}{l}\text { Depth of } \\
\text { sample } \\
\text { (ft) }\end{array}$ & Lithologic type & $\begin{array}{l}\text { Porosity } \\
\text { (percent) }\end{array}$ & $\begin{array}{l}\text { Graln density } \\
\left(\mathrm{g} / \mathrm{cm}^{3}\right)\end{array}$ & $\begin{array}{c}\text { Permeability to } \\
\text { air } \\
\text { (mD) }\end{array}$ & $\begin{array}{c}\text { Hydraullc } \\
\text { conductivity' } \\
\text { (ftd) }\end{array}$ \\
\hline C9V & $66.0-66.5$ & Sandstone & 16.0 & 2.65 & 1.96 & $6.9 \times 10^{-4} c$ \\
\hline $\mathrm{ClOV}$ & $73.5-73.7$ & Shale & 3.4 & 2.57 & -.- & -- \\
\hline $\mathrm{C} 11 \mathrm{H}$ & $76.0-76.6$ & Wadge coal & 2.6 & 1.32 & -- & --- \\
\hline $\mathrm{C} 12 \mathrm{~V}$ & $86.6-87.1$ & Sandstone & 14.8 & 2.63 & .247 & $1.9 \times 10^{-5} \mathrm{~m}$ \\
\hline $\mathrm{C} 13 \mathrm{H}$ & $90.2-91.2$ & Shale & 5.0 & 2.56 & .0013 & --- \\
\hline $\mathrm{C} 13 \mathrm{~V}$ & $90.2-91.2$ & Shale & 5.4 & 2.59 & .0016 & --- \\
\hline $\mathrm{C} 15 \mathrm{H}$ & $106.2-106.7$ & Sandstone & 10.5 & 2.68 & .178 & $4.2 \times 10^{-5} \mathrm{~m}$ \\
\hline $\mathrm{C} 15 \mathrm{~V}$ & $106.2-106.7$ & Sandstone & 10.6 & 2.68 & .067 & $7.4 \times 10^{-6} \mathrm{c}$ \\
\hline $\mathrm{C} 16 \mathrm{H}$ & $114.5-114.9$ & Sandstone & 4.5 & 2.66 & --- & --- \\
\hline $\mathrm{C} 17 \mathrm{~V}$ & $118.8-119.2$ & Shale & 1.4 & 2.47 & --- & -- \\
\hline Z1V & $165.8-166.1$ & Shale & 5.2 & 2.90 & 0.039 & -- \\
\hline $\mathrm{Z} 2 \mathrm{~V}$ & $176.0-176.5$ & Sandstone & 6.0 & 2.64 & .030 & $2.5 \times 10^{-6} \mathrm{c}$ \\
\hline $\mathrm{Z3H}$ & $181.2-181.6$ & Lennox coal & 2.8 & 1.30 & .858 & $2.1 \times 10^{-6} \mathrm{~m}$ \\
\hline $\mathrm{ZAV}$ & $184.8-185.3$ & Shale & 3.8 & 2.32 & $\cdots$ & --- \\
\hline $\mathrm{Z6H}$ & $193.7-194.2$ & Sandstone & 16.1 & 2.64 & 2.07 & $7.4 \times 10^{-4} c$ \\
\hline $\mathrm{Z7H}$ & $208.5-209.0$ & Sandstone & 18.5 & 2.65 & 22.7 & $1.7 \times 10^{-2} \mathrm{~m}$ \\
\hline $\mathrm{Z8V}$ & $220.0-220.5$ & Sandstone & 18.4 & 2.66 & 13.8 & $7.5 \times 10^{-3} \mathrm{~m}$ \\
\hline $\mathrm{Z9H}$ & $230.8-231.3$ & Wadge coal & 3.5 & 1.40 & .152 & $<2.1 \times 10^{-6} \mathrm{~m}$ \\
\hline $\mathrm{Z} 10 \mathrm{~V}$ & $237.1-237.7$ & Sandstone & 10.7 & 2.65 & .022 & $1.7 \times 10^{-6} \mathrm{c}$ \\
\hline $\mathrm{Z} 14 \mathrm{H}$ & $250.5-251.0$ & Sandstone & 12.7 & 2.69 & 1.31 & $4.0 \times 10^{-4} \mathrm{c}$ \\
\hline $\mathrm{Z} 15 \mathrm{H}$ & $258.4-258.9$ & Sandstone & 6.1 & 2.70 & $<.01$ & $<2.1 \times 10^{-6} \mathrm{~m}$ \\
\hline B3V & $55.2-55.6$ & Shale & 3.6 & 2.55 & --- & -- \\
\hline B4V & $70.8-71.5$ & Shale & 5.5 & 2.64 & -.- & -- \\
\hline $\mathrm{B} 6 \mathrm{~V}$ & $86.5-87.0$ & Sandstone & 9.9 & 2.66 & 0.249 & $4.3 \times 10^{-5} \mathrm{c}$ \\
\hline B7H & $95.4-95.9$ & Lennox coal & 3.9 & 1.31 & .118 & $<2.1 \times 10^{-6} \mathrm{~m}$ \\
\hline B8V & $103.7-104.2$ & Sandstone & 9.3 & 2.63 & .011 & $7.0 \times 10^{-7} \mathrm{c}$ \\
\hline $\mathrm{B} 10 \mathrm{H}$ & $119.1-119.6$ & Sandstone & 15.5 & 2.66 & 3.62 & $1.8 \times 10^{-3} \mathrm{~m}$ \\
\hline $\mathrm{B} 10 \mathrm{~V}$ & $119.1-119.6$ & Sandstone & 15.6 & 2.66 & 2.08 & $7.5 \times 10^{-4} c$ \\
\hline B11H & $128.5-129.0$ & Sandstone & 15.5 & 2.65 & 2.83 & $1.1 \times 10^{-3} \mathrm{c}$ \\
\hline B11V & $128.5-129.0$ & Sandstone & 16.4 & 2.66 & 3.45 & $1.5 \times 10^{-3} \mathrm{c}$ \\
\hline B13H & $145.0-145.4$ & Sandstone & 13.0 & 2.67 & .951 & $3.1 \times 10^{-4} \mathrm{~m}$ \\
\hline B14V & $152.7-153.2$ & Shale & 4.3 & 2.59 & --- & -- \\
\hline B15H & $159.9-160.5$ & Wadge coal & 4.1 & 1.30 & --- & --- \\
\hline B16V & $168.6-169.0$ & Shale & 5.8 & 2.47 & --- & -- \\
\hline $\mathrm{B} 17 \mathrm{H}$ & $171.3-171.8$ & Sandstone & 13.5 & 2.67 & 1.47 & $6.6 \times 10^{-4} \mathrm{~m}$ \\
\hline
\end{tabular}

${ }^{1}$ Some values of hydraulic conductivity calculated from gas-permeability values in sandstone samples are reported as less than the laboratory detection level. 


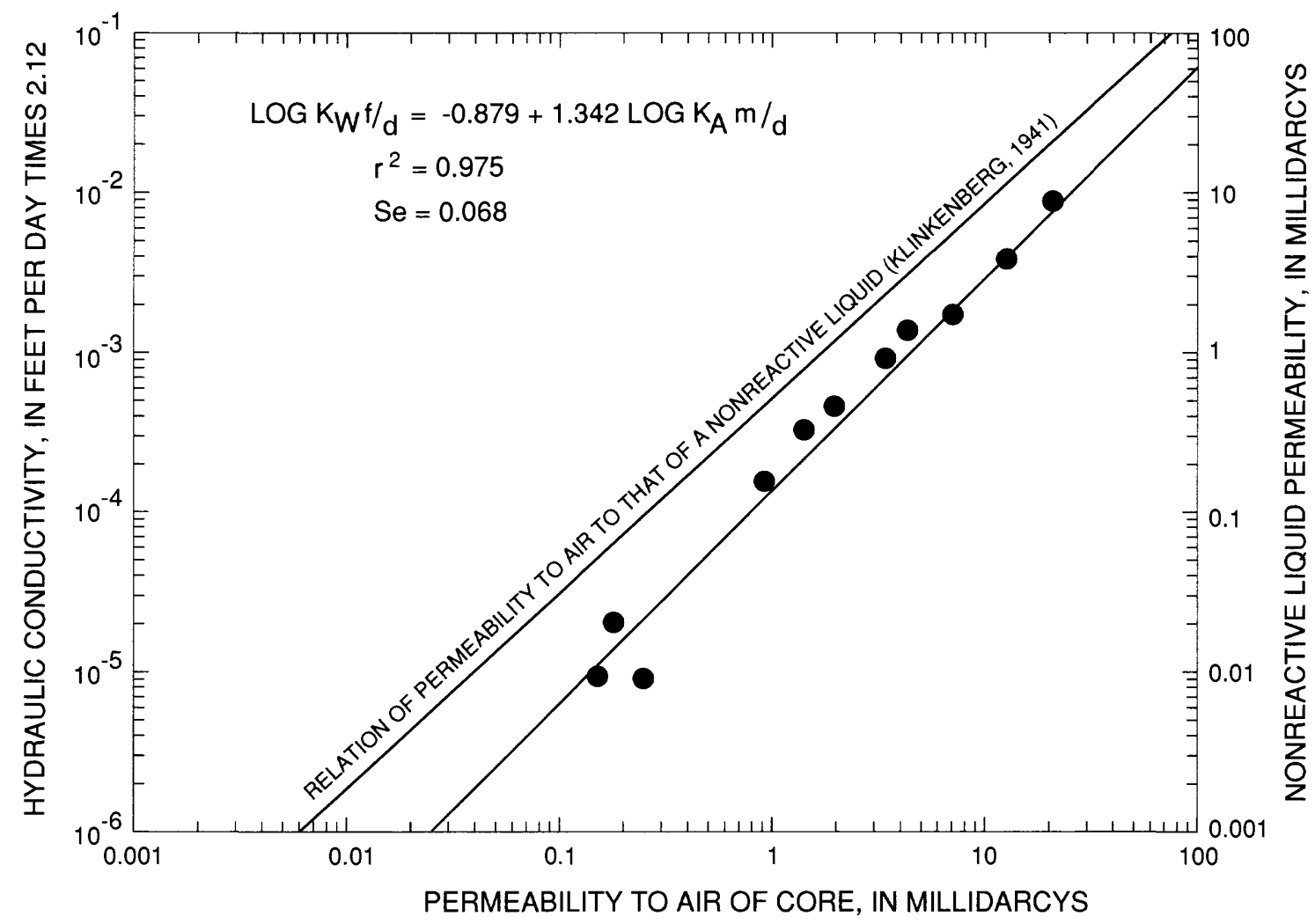

Figure 20. Relation between permeability to air of core and hydraulic conductivity for sandstone core samples.

Because the hydraulic conductivity of the coal and shale core samples could not be adequately measured, comparisons of hydraulic-conductivity values between different lithologic samples could not be made. However, permeability to air values calculated using all of the horizontal and vertical cores that were gas tested indicate that sandstones, which had a geometric mean of $0.75 \mathrm{mD}$, are only slightly more permeable to air than the coals that had a geometric mean of $0.58 \mathrm{mD}$, and are more than two orders of magnitude more permeable to air than the shales that had a geometric mean of $6.6 \times 10^{-3} \mathrm{mD}$. The hydraulicconductivity values for the 32 sandstone samples, using all of the gas- and water-tested cores, ranged from $7.0 \times 10^{-7}$ to $4.8 \times 10^{-2} \mathrm{ft} / \mathrm{d}$ with a geometric mean of $1.9 \times 10^{-4} \mathrm{ft} / \mathrm{d}$.

\section{Comparison of Aquifer and Core Hydraulic Properties}

Hydraulic-conductivity values determined from aquifer tests were compared to the hydraulic- conductivity values obtained from core-sample analysis (table 4). The hydraulic-conductivity values from core tests reported in table 4 represent the largest measured horizontal hydraulic-conductivity value from core in the completed interval. Aquifer-test values for hydraulic conductivity were at least an order of magnitude larger than the values from core-sample analyses (table 4). The presence of secondary porosity in the natural environment or from man-induced processes probably accounts for the difference. Hydraulicconductivity values calculated from core-sample analysis, if used with caution, may be indicative of minimum values. However, before core hydraulicconductivity values are used, especially when modeling ground-water flow and solute transport, they must be compared with values from aquifer tests to see if they represent onsite conditions.

Core hydraulic-conductivity values were not reported for some lithologic units because laboratory permeability tests require solid sections of core. Because fractured core cannot be tested for permeability, some core, such as coal that was naturally fractured, could not be tested. Therefore, laboratory permeability 
tests were done on sections of core that came from lithologic units that were unfractured. Consequently, the permeability results probably represent rock unaffected by natural fractures or fractures caused by mining.

Aquifer hydraulic properties in the vicinity of mining can be affected by the mining process. Fielddetermined hydraulic-conductivity values (table 4) indicate that bedrock aquifers near reclaimed spoil (Spring Creek and Cow Camp Creek) generally have larger hydraulic-conductivity values than the same bedrock aquifers at unmined sites (Zuli and Bond Creek).

The difference in hydraulic-conductivity values between bedrock aquifers near mining and the unmined sites might be a function of depth. The reason the sites are unmined is because the coal is too deep for economical coal recovery. The greater depth might result in a greater amount of overburden pressure; thus, fewer fractures and less hydraulic conductivity. Another reason for the difference could be proximity to mining. Mining activity (such as blasting, heavy equipment movement, and so forth) could have caused secondary porosity in bedrock aquifers near mining and thus enhanced the hydraulic conductivity of the rocks.

Aquifer tests of bedrock were done at the Bond Creek site before a landslide occurred. To determine whether hydraulic properties changed immediately after the landslide, additional aquifer tests were done (table 4). The difference in hydraulic-conductivity values from 1989 to 1990 at the Bond Creek site do not indicate any conclusive changes. Changes in hydraulic conductivity could occur as mining progresses. Additional aquifer tests need to be done at the Bond Creek site after reclamation if the effects of mining on hydraulic conductivity in the bedrock aquifers are to be determined.

\section{Surface Water}

Two types of surface-water flow were monitored in the study area-streams and springs. Streams flowing from the study area before mining generally were ephemeral or intermittent.

\section{Streams}

Gaging stations were established at the Spring Creek and Cow Camp Creek sites to measure the discharge in streams that flowed along the edges of the reclaimed spoil (figs. 5 and 6). Although some waterquality samples were collected at the gaging stations, very little usable data were obtained from either stream site. At Spring Creek, two major thunderstorms caused an excessive quantity of sediment to be transported in the runoff, which buried the gaging station flume under $2 \mathrm{ft}$ of sediment. Because a continuous buildup of sediment at the station was expected during the study, a stage-discharge relation could not be developed at the station, and data collection at the station ceased. At Cow Camp Creek, no flow occurred at the gaging station. All surface-water flow infiltrated into the ground before reaching the gage, thereby eliminating the usefulness of the station.

\section{Springs}

Springs flow from the reclaimed-spoil aquifer at the Spring Creek and Cow Camp Creek sites (fig. 4). The hydrographs of spring flow have steeply rising and falling limbs that respond similarly to typical stream hydrographs during spring runoff (figs. 21 and 22). However, unlike stream runoff, the springs show little or no response to rainfall. This lack of response indicates that during summer, most of the rain falling on the reclaimed spoil does not percolate to the saturated zone of the reclaimed-spoil aquifer.

The hydrographs of the water levels in the reclaimed-spoil aquifers and of discharge from the springs have similar seasonal responses (figs. 14, 15,21 , and 22). This similarity indicates that the reclaimed-spoil aquifers are the probable source of flow in the springs at Spring Creek and Cow Camp Creek.

Collection of accurate data at the gaging stations for the springs was difficult. Ponds were excavated to capture and gage the flow from the springs. By the end of the study, sediment had completely filled the pond at the Spring Creek site. Consequently, towards the end of the study, the recorder float was resting on bottom sediment, which compromised the accuracy of the recorded water levels. Moss grew and debris collected in the ponds at both gaging stations for the springs. The moss and debris periodically would break loose and lodge on the control, thus disrupting the stagedischarge relation. Placing oil-type pontoons around the control to catch the moss and debris was an effective technique to prevent this problem.

\section{Recharge, Discharge, and Water Balance in Reclaimed-Spoil Aquifers}

Recharge, discharge, and water balance in the reclaimed-spoil aquifers were measured and calculated by using data collected at the study sites. The hydrogeologic information collected included climatologic, 


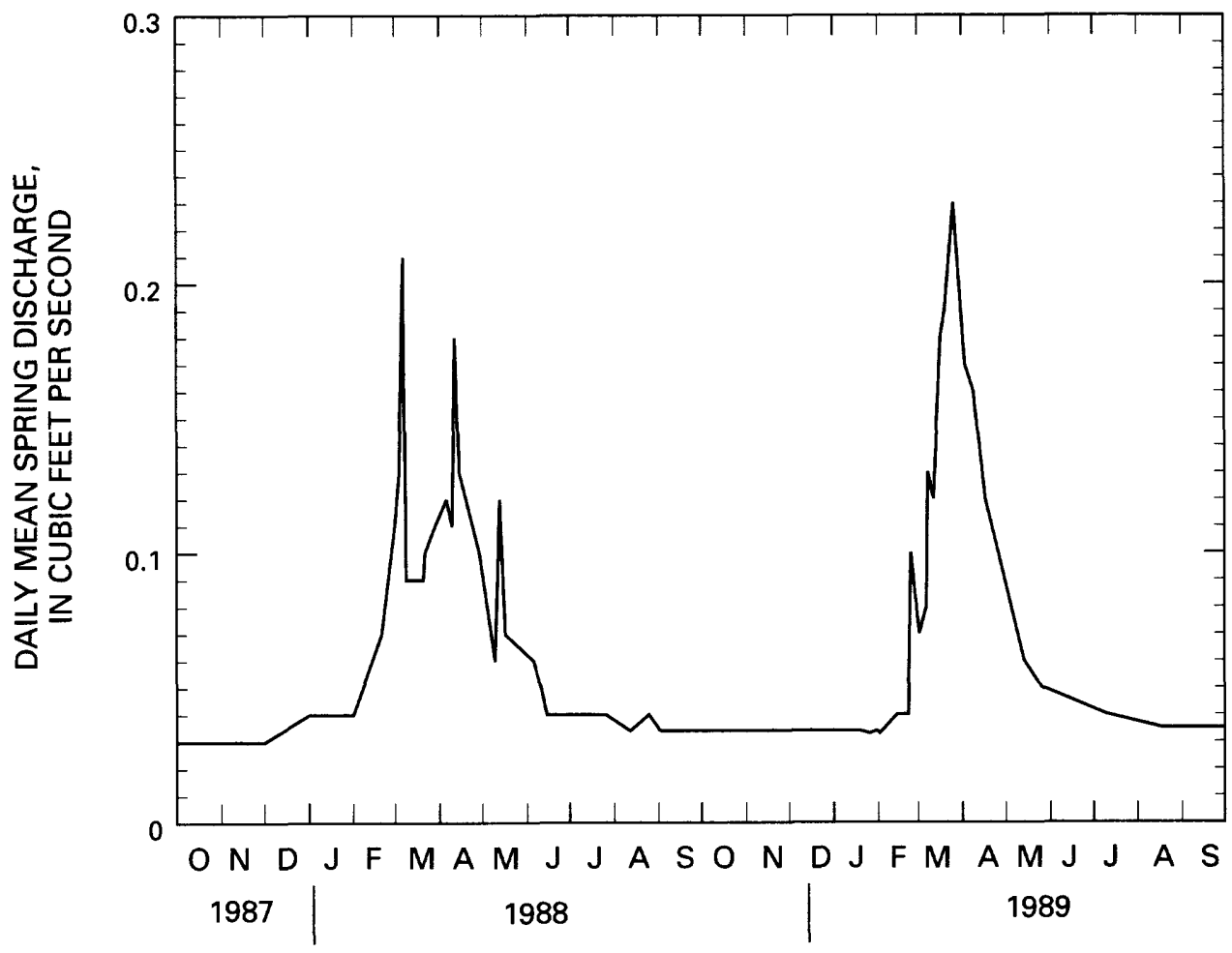

Figure 21. Daily mean discharge for the spring at the Spring Creek site, water years 1988-89.

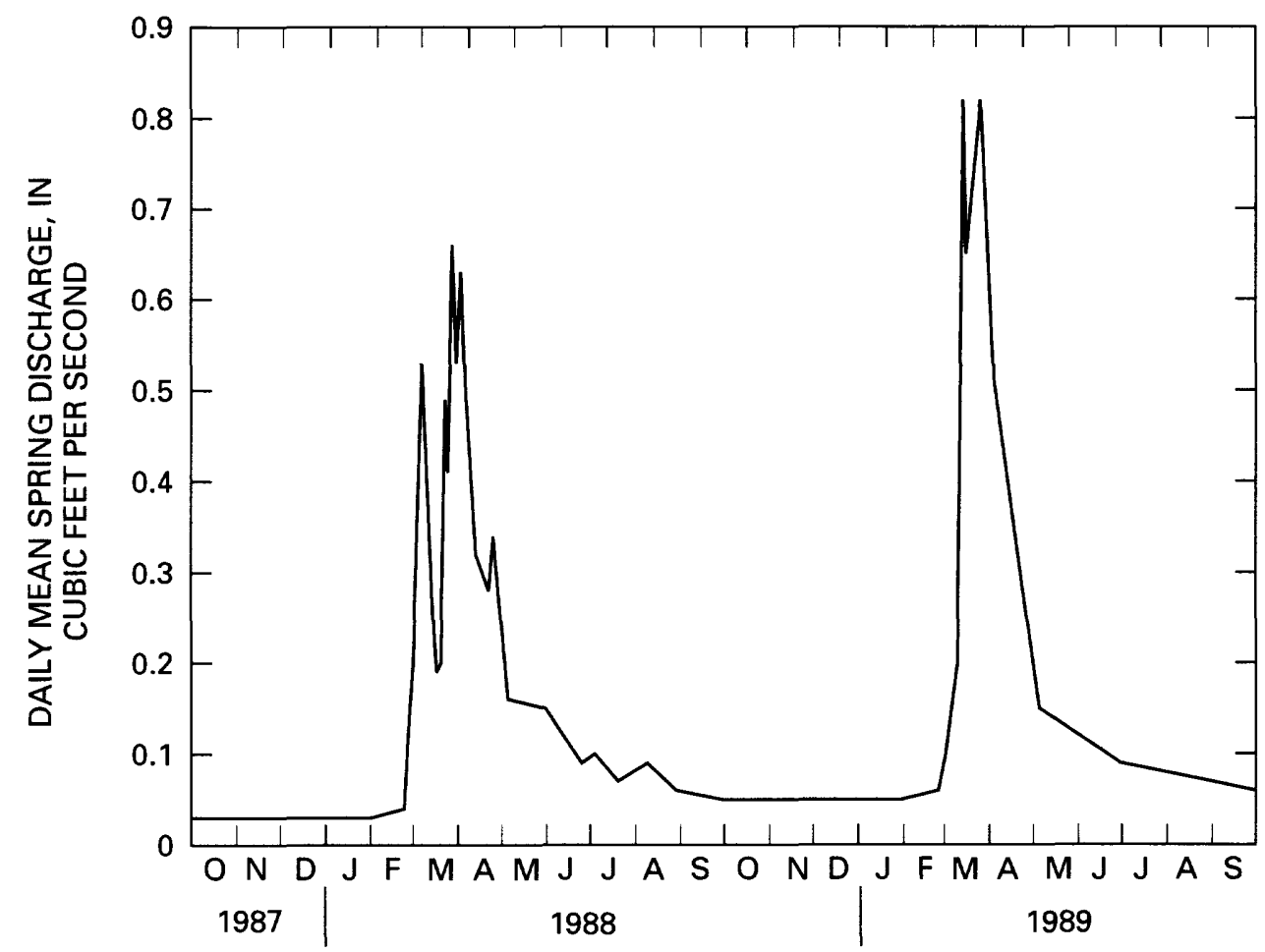

Figure 22. Daily mean discharge for the spring at the Cow Camp Creek site, water years 1988-89. 
soil-water, ground-water, geologic, surface-water, and water-quality data. The data are listed in a report by Williams and others (1992).

Several components of the hydrologic system that were monitored can be combined to delineate the flow paths through the reclaimed spoil. Snow melted at the study sites from the end of February to the end of March. During this snowmelt period, the soil-water content increased (figs. 10 to 13 ) and water began to collect in the lysimeters. In coincidence with snowmelt and increased soil-water content came a rapid rise in the water table in the reclaimed-spoil aquifers (figs. 14 and 15) and increased discharge from the springs (figs. 21 and 22). During the snowmelt period, the bedrock aquifers also had increases in hydraulic head (figs. 16 to 19). These hydrologic responses to snowmelt indicate the importance of snowmelt in driving the entire hydrologic system and the rapidity of response to snowmelt in the reclaimed-spoil environment.

Snowmelt and underburden aquifers contribute to the reclaimed-spoil aquifer. The response of the unsaturated and saturated zones to snowmelt and the hydraulic head in the bedrock aquifers both show the potential for water movement into the reclaimed-spoil aquifer. In general, each system contributes about 50 percent of the recharge to the reclaimed-spoil aquifer. Chemical and geochemical data also indicate both snowmelt and bedrock aquifers contribute water to the reclaimed-spoil aquifer.

Underburden aquifers also seem to contribute water to the reclaimed-spoil aquifers. Hydraulic-head measurements in the underburden and reclaimed-spoil aquifers indicate the potential for upward movement of water from the underburden aquifer to the reclaimedspoil aquifer. Stable-isotope analysis confirms the presence of recharge water from the underburden aquifer in the reclaimed-spoil aquifer. Consequently, recharge to the reclaimed-spoil aquifer is derived from snowmelt and underburden aquifers.

A hydrograph-separation approach was used to calculate the quantity of recharge to the reclaimed-spoil aquifers at the Spring Creek and Cow Camp Creek sites. Two sources of inflow (recharge) to the reclaimed-spoil aquifers were considered; snowmelt and subsequent percolation of soil water (surface recharge) and recharge from underburden aquifers. Outflow from the reclaimed-spoil aquifers (spring discharge) was calculated from the stage-discharge relation established at the spring gages. Discharge from the reclaimed-spoil aquifers to downgradient bedrock aquifers was quantified using the hydraulic conductivity of the undisturbed bedrock material, the cross-sectional area of undisturbed bedrock in contact with the spoil aquifers, and the hydraulic gradient mea- sured between the reclaimed-spoil aquifer wells and downgradient bedrock wells. These calculated volumes of discharge from the reclaimed-spoil aquifers to the bedrock aquifers constitute about one percent of the annual 1.7 and 4.0 million cubic feet of water discharged respectively from the springs at the Spring Creek and Cow Camp Creek sites. For the massbalance calculations of water movement in the reclaimed-spoil aquifers, the discharge to the bedrock aquifers was therefore considered negligible.

\section{Hydrographs of spring discharge for Spring} Creek and Cow Camp Creek during water years 1988 and 1989 are shown in figures 21 and 22. Hydrographseparation techniques were used to determine the percentage of spring discharge water derived from surface recharge and from the underburden aquifer recharge (figs. 23 and 24). Several hydrograph-separation techniques are available (Linsley and others, 1975; Dunne and Leopold, 1978; Nathan and McMahon, 1990). The quantity of water recharged to the reclaimed-spoil aquifer from the underburden aquifer was quantified at both sites by determining a unit value of hydraulic conductivity for flow between the underburden aquifer and the reclaimed-spoil aquifer through a unit cross-sectional area. During low-flow, when discharge from the springs is at a minimum, recharge to the reclaimedspoil aquifer from the surface is negligible, and recharge to the reclaimed-spoil aquifer is derived almost entirely from the underburden aquifer. Therefore, at low flow, the quantity of water discharging from the spring is about equal to the quantity of water recharging the reclaimed-spoil aquifer from the underburden aquifer. Darcy's law applied to flow through a porous media can be represented by the following equation (Freeze and Cherry, 1979):

$$
Q=-K A\left(h_{2}-h_{1}\right) / L
$$

where $\mathrm{Q}$, in the mine-site setting, represents the quantity of water recharged from the underburden aquifer to the reclaimed-spoil aquifer, in cubic feet per second; $K$ is the unit hydraulic conductivity for flow from the underburden aquifer to the reclaimed-spoil aquifer, in feet per second; $A$ is the cross-sectional area of flow, in square feet; $h_{2}$ is the hydraulic head in the reclaimedspoil aquifer, in feet; $h_{1}$ is the hydraulic head in the underburden aquifer, in feet; and $L$ is the length of the flow path from the underburden aquifer to the reclaimed-spoil aquifer, in feet. Because $K, A$, and $L$ remain constant throughout the year, changes in $Q$ are directly proportional to changes in $h_{2}-h_{1}$. At low flow, the quantity of water discharging from the spring is assumed to equal $Q$. Because $h_{1}$ and $h_{2}$ can be mea- 


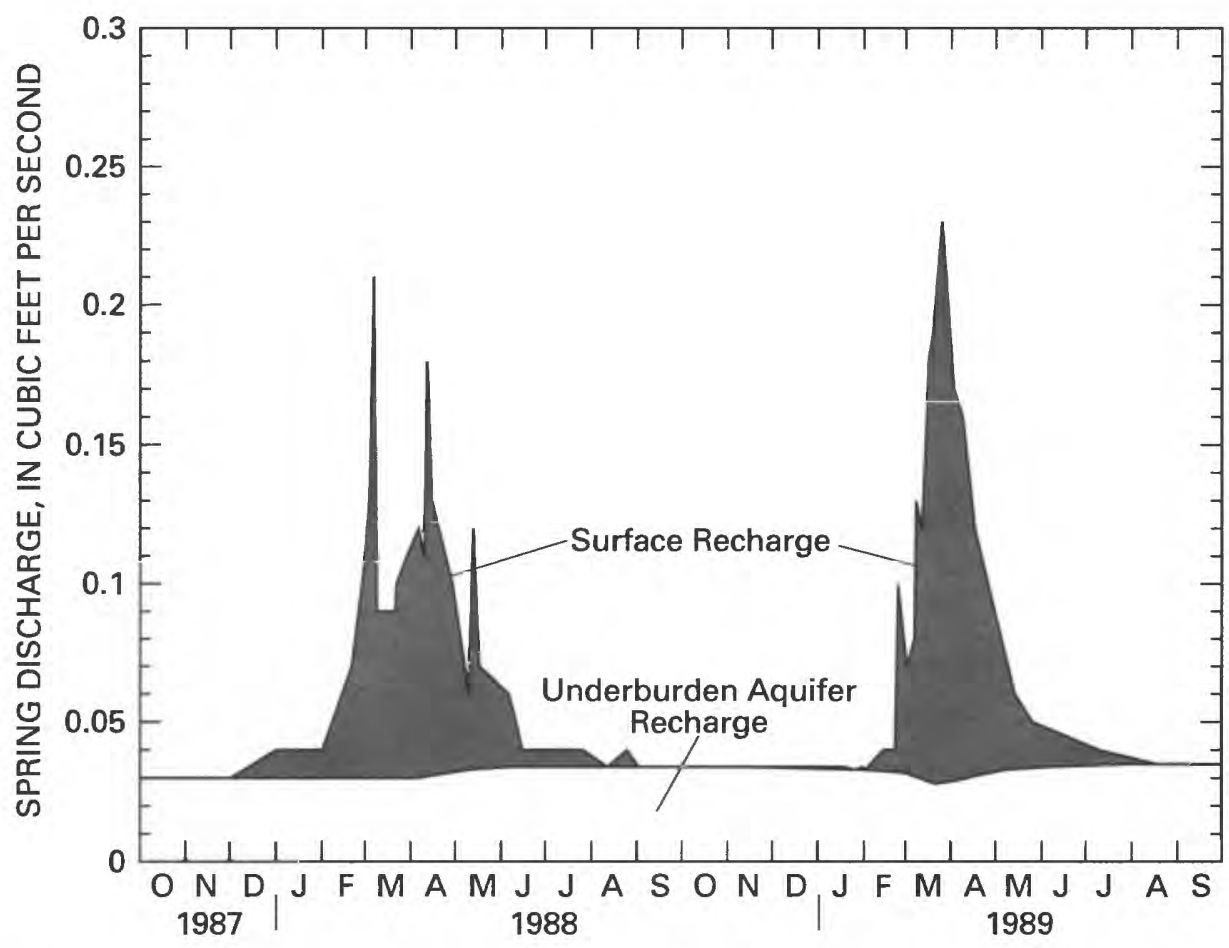

Figure 23. Spring discharge at the Spring Creek site and the contributions from surface recharge, October 1987-September 1989.

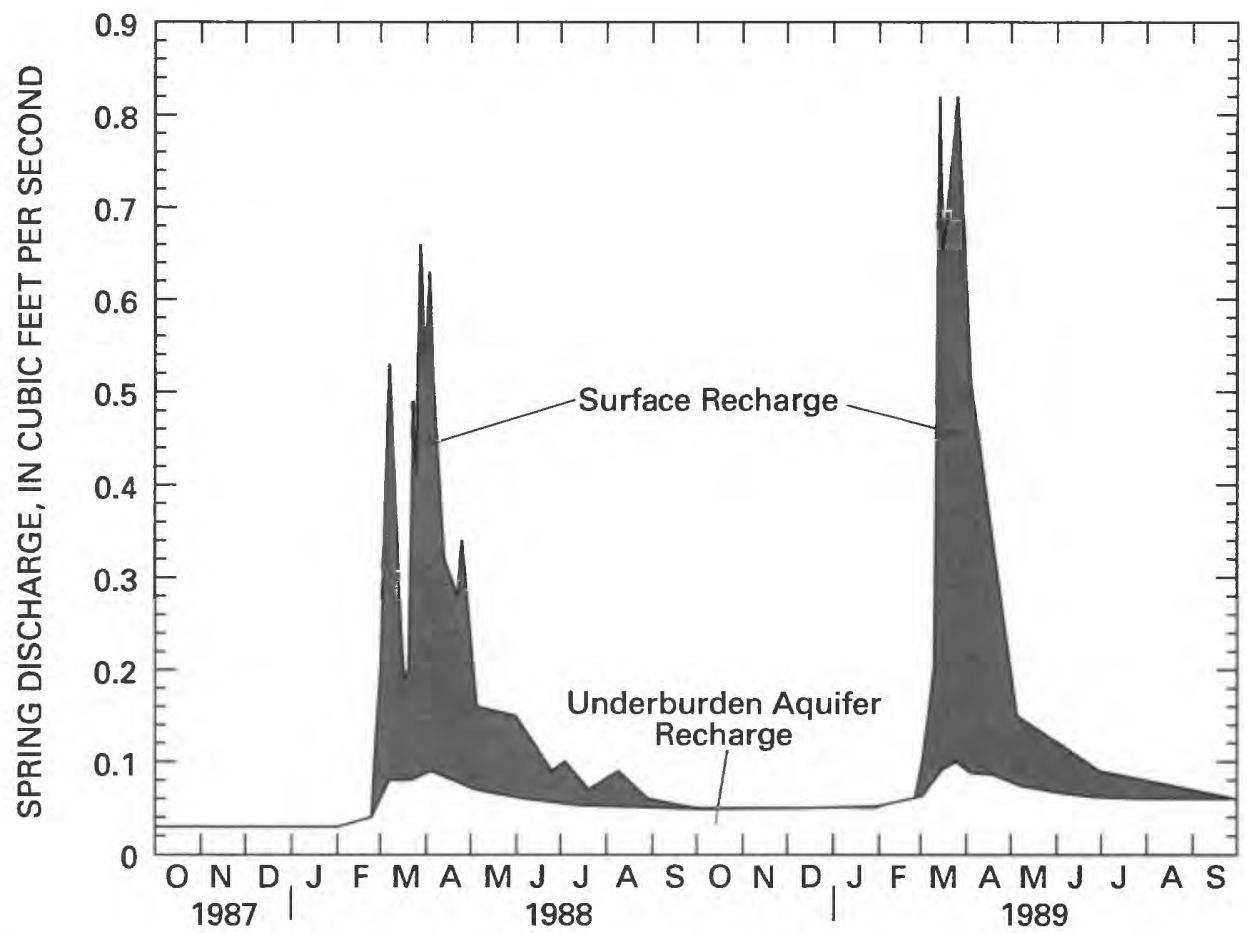

Figure 24. Spring discharge at the Cow Camp Creek site and the contributions from surface recharge and underburden aquifer recharge, October 1987-89. 
sured, a value for $K A / L$ can be calculated by the following equation:

$$
K A / L=Q /\left(h_{1}-h_{2}\right)
$$

The calculated value of $K A / L$ is assumed to remain constant and can be used with measured values of $h_{1}-h_{2}$ to calculate underburden aquifer recharge to the reclaimed-spoil aquifer throughout the year by rearranging equation 2 as follows:

$$
Q=\frac{K A}{L}\left(h_{1}-h_{2}\right)
$$

Use of this method to separate surface recharge and underburden aquifer recharge during water years 1988 and 1989 yields the numbers listed in table 6 . While estimated recharge from the underburden aquifer to the reclaimed-spoil aquifer remained nearly constant during spring snowmelt at Spring Creek (fig. 23), during spring snowmelt at Cow Camp Creek (fig. 24), estimated recharge from the underburden to the reclaimed-spoil aquifer increased. This was due to a larger increase in the water level of the underburden aquifer at Cow Camp Creek as compared to the waterlevel change in the reclaimed-spoil aquifer. At Spring Creek, the springtime increase in hydraulic head in the underburden aquifer was offset by an equal or larger increase in the water level of the reclaimed-spoil aquifer. As noted in the "Use of Isotopes to Characterize Recharge and Ground-Water Flow" section, surface recharge and underburden aquifers each contribute about 50 percent of the water to the reclaimed-spoil aquifers.

On the basis of calculated values for surface recharge in table 6, and using approximately 3 in. of annual surface recharge as indicated by the lysimeter recharge through the reclaimed-spoil material, estimates of the size of the area contributing surface recharge to the reclaimed-spoil aquifer at the Spring
Creek and Cow Camp Creek sites can be calculated. These calculations indicate that at Spring Creek, the contributing area of surface recharge to the reclaimedspoil aquifer encompasses about 65 acres. At Cow Camp Creek, the reclaimed-spoil aquifer receives surface recharge from an area of about 190 acres. Although these calculated areas seem reasonable on the basis of site maps, actual areas of contribution are difficult to delineate in the field for an area that has been extensively mined and subsequently reclaimed.

\section{GEOCHEMISTRY}

Samples were collected for water-quality analysis from lysimeters, wells, and springs. The data were used to describe water quality at the study sites, interpret flow paths and sources of recharge, and provide input to geochemical models. The quality of water from batch-mixing experiments also was evaluated.

\section{Processes Controlling Water Quality}

Four processes probably control most of the chemical evolution of ground water at the study area. These processes include recharge and percolation of snowmelt water that contains $\mathrm{CO}_{2}$ and $\mathrm{O}_{2}$ gases, dissolution and precipitation of carbonate and sulfate minerals, oxidation of pyrite, and cation exchange reactions.

When water infiltrates the soil surface and percolates through the soil profile, it carries with it dissolved $\mathrm{CO}_{2}$ and $\mathrm{O}_{2}$ gases. These gases may have a substantial effect on the chemical composition of water as it moves below the root zone and into the underlying bedrock material. In soils where biochemical decay of organic material is extensive, percolating water may obtain even larger quantities of dissolved $\mathrm{CO}_{2}$ as the water moves through the upper soil horizons. Values of $\mathrm{pH}$ in the shallow soil zone can be as acidic as 4.3 in response

Table 6. Results of calculations for recharge to the reclaimed-spoil aquifers at Spring Creek and Cow Camp Creek from surface recharge and underburden aquifer recharge during water years 1988 and 1989

[Recharge values in acre-feet; numbers in parenthesis are percentage of total recharge]

\begin{tabular}{lllllc}
\hline & \multicolumn{3}{c}{ Site } \\
\cline { 2 - 3 } Source of recharge & \multicolumn{2}{c}{ Spring Creek } & & \multicolumn{2}{c}{ Cow Camp Creek } \\
\cline { 2 - 3 } & 1988 & 1989 & & 1988 & 1989 \\
\hline Surface & $16.9(42)$ & $16.3(41)$ & & $44.8(54)$ & $50.9(53)$ \\
Underburden aquifer(s) & $23.2(58)$ & $23.8(59)$ & & $37.7(46)$ & $45.0(47)$ \\
Total & $40.1(100)$ & $40.1(100)$ & & $82.5(100)$ & $95.9(100)$ \\
\hline
\end{tabular}


to these increased concentrations of $\mathrm{CO}_{2}$ gas (Freeze and Cherry, 1979). As the soil water percolates below the root zone, it contacts minerals with which it can react. If the percolating water is acidic from dissolution of $\mathrm{CO}_{2}$ gas, the mineral-water reactions may be enhanced. If the water reaching the mineral-rich zone contains dissolved oxygen, minerals such as pyrite, which are subject to oxidation-reduction reactions, can be oxidized to release large quantities of acid, which in turn can dissolve large quantities of solids into the ground water.

Carbonate minerals, such as calcite $\left(\mathrm{CaCO}_{3}\right)$ and dolomite $\left[\mathrm{CaMg}\left(\mathrm{CO}_{3}\right)_{2}\right]$, if present in the geologic medium, commonly react with water. In acidic water, dissolution of calcite and dolomite occurs relatively quickly. Saturation with respect to these minerals can occur within hours to days depending on the rates of flow through the geologic medium (Raush and White, 1977). The dissolution of calcite and dolomite with the production of calcium, magnesium, and bicarbonate ions can be indicated by the following reactions (s indicates solid mineral):

$$
\mathrm{CaCO}_{3}(\mathrm{~s})+\mathrm{H}^{+}<-->\mathrm{Ca}^{2+}+\mathrm{HCO}_{3}^{-}
$$

$$
\mathrm{CaMg}\left(\mathrm{CO}_{3}\right)_{2}(\mathrm{~s})+2 \mathrm{H}^{+}<-->\mathrm{Ca}^{2+}+\mathrm{Mg}^{2+}+2 \mathrm{HCO}_{3}{ }^{-}
$$

Carbonate dissolution is the main mechanism by which bicarbonate enters the water in sedimentary-rock aquifers. Typical bicarbonate concentrations in ground water derived from rocks containing calcite and dolomite range from 200 to $500 \mathrm{mg} / \mathrm{L}$ (Groenewold and others, 1983). In most sedimentary rock ground-water systems, carbonate dissolution can buffer naturally produced acid and still maintain $\mathrm{pH}$ values in the nearneutral range. The dissolution of calcite and dolomite will continue until the ground water reaches equilibrium with respect to these two minerals.

Pyrite $\left(\mathrm{FeS}_{2}\right)$ can react in the presence of oxygenated water. Mineralogic analysis of core samples from nearby mines (Hounslow and others, 1978) and core samples collected from the Cow Camp Creek site indicate pyrite is disseminated throughout the rocks that comprise the Wadge coal overburden. Pyrite also was observed as secondary deposits contained in small fractures in core samples collected at all of the study sites. Pyrite oxidation is one of the strongest acidproducing reactions in nature and causes most of the problems associated with acid mine drainage in the United States. The overall stoichiometric oxidation of pyrite to form sulfate ions, acidity, and insoluble iron hydroxide $\left(\mathrm{Fe}(\mathrm{OH})_{3}\right)$ can be represented by the following set of reactions (Stumm and Morgan, 1981).

$$
\begin{gathered}
\mathrm{FeS}_{2}(\mathrm{~s})+7 / 2 \mathrm{O}_{2}+\mathrm{H}_{2} \mathrm{O}<-->\mathrm{Fe}^{2+}+2 \mathrm{SO}_{4}{ }^{2-}+2 \mathrm{H}^{+}(6) \\
\mathrm{Fe}^{+2}+1 / 4 \mathrm{O}_{2}+\mathrm{H}^{+}<-->\mathrm{Fe}^{3+}+1 / 2 \mathrm{H}_{2} \mathrm{O} \\
\mathrm{Fe}^{3+}+3 \mathrm{H}_{2} \mathrm{O}<-->\mathrm{Fe}(\mathrm{OH})_{3}(\mathrm{~s})+3 \mathrm{H}^{+}
\end{gathered}
$$

In the semiarid environment of the study area, evaporation and transpiration exceed precipitation. As a result, near-surface water becomes concentrated with dissolved solids resulting in the formation of salts. In a system controlled by reactions 4 through 8, gypsum $\left(\mathrm{CaSO}_{4}\right)$, epsomite $\left(\mathrm{MgSO}_{4}\right)$, and calcite salts precipitate from water supersaturated with calcium, magnesium, sulfate, and bicarbonate. Successive wetting and drying events can result in a large accumulation of these salts in the upper few feet of the soil profile. During large infiltration events, substantial quantities of water can move through the soil profile, redissolving the accumulated salts and transporting them to the water table. Shales are another source of amorphous efflorescent salts. Gypsum and epsomite in particular are abundant in shales of Cretaceous age (McWhorter and others, 1975).

Cation-exchange is the primary reaction by which water in the study area obtains dissolved sodium. Clay minerals, which are abundant in Cretaceous rocks, typically have large quantities of sodium adsorbed on their surfaces. As water moves along a flowpath and contacts these sodium-rich clays, water is softened naturally as calcium and magnesium exchange for sodium on the adsorption sites. The reaction can be expressed as follows:

$$
\mathrm{M}^{2+}+2 \mathrm{NaX}<-->2 \mathrm{Na}^{+}+\mathrm{MX}_{2}
$$

where $\mathrm{M}$ indicates calcium or magnesium, and $\mathrm{X}$ indicates the exchange site on a clay-mineral edge. Shales in particular are composed of clay minerals and, thus, are a primary source of sodium.

\section{Chemical Evolution of Water in Undisturbed Bedrock Aquifers}

Ground-water quality is affected by several factors along a flow path. In a closed system that contains pyrite, as would be represented by an undisturbed ground-water environment at the study area, oxidation of pyrite is limited by the lack of dissolved oxygen in the ground water. As the water percolates through the soil and into the saturated zone, dissolved oxygen is consumed and pyrite oxidation ceases. The lack of oxygen limits the quantity of sulfate and acid that ground water can gain from pyrite in an undisturbed system. The acid that is produced when small quantities of pyrite are oxidized is effectively buffered by 
reaction with carbonate minerals. If dissolved oxygen is available and is constantly supplied to the ground water as pyrite dissolves, additional pyrite will be oxidized resulting in an increase in dissolved sulfate and acidity. Water in a natural, closed system dominated by reactions 4 and 5, and to a limited extent reactions 6 through 8 , would be a calcium magnesium bicarbonate water with a small quantity of dissolved sulfate and a $\mathrm{pH}$ in the neutral to basic range.

As the water described in the previous paragraph moves farther along the ground-water flow path, it comes into contact with clay minerals, which are a source of sodium through cation-exchange reactions. As cation-exchange removes calcium and magnesium from solution, the water becomes undersaturated with respect to calcite and dolomite. This undersaturation could result in further dissolution of calcite and dolomite, which increases the concentration of bicarbonate in the ground water. The dissolved solids in the resultant water primarily are composed of sodium and bicarbonate, with smaller amounts of calcium, magnesium, and sulfate. This type of water is typical of samples collected from aquifers that are undisturbed by mining.

\section{Chemical Evolution of Water in Reclaimed-Spoil Aquifers}

The reactions controlling water quality at a mine site are, in general, the same reactions that control water quality in an undisturbed setting. However, the degree to which these reactions occur probably controls the differences in the chemistry of water collected from reclaimed spoil and from undisturbed aquifers.

The water in the reclaimed-spoil aquifers and associated springs is a calcium-magnesium-sulfate type with dissolved-solids concentrations two to four times larger than in water from undisturbed bedrock aquifers. The difference in the water quality between undisturbed and disturbed aquifers can be explained with an understanding of the physical and chemical changes that occur during mining operations.

The initial disruption of overburden material presents the opportunity for several geochemical reactions. Geochemical alterations begin as the rocks, which were previously in a mildly reducing environment, are broken up and exposed to the atmosphere. Substantial alterations may result when the rocks are placed in spoil piles and are exposed to oxygen and water during the removal of the coal. The chemical reactivity of minerals increases dramatically because of a large supply of atmospheric oxygen and a large quantity of freshly exposed rock surface. Pyrite oxidation, which is limited by available oxygen in an undisturbed setting, can occur readily and result in the production of extremely acidic water and large concentrations of dissolved sulfate. The acid produced from the oxidation of pyrite has a corrosive effect on carbonate minerals and thereby increases the dissolution of calcite and dolomite. The resultant water has large concentrations of calcium, magnesium, sulfate, and bicarbonate. Depending on the amount of carbonate minerals present, the water may or may not be buffered. In situations where the acid production exceeds the buffering capacity (acidic $\mathrm{pH}$ ), reactions involving mobilization of trace metals may be important.

Amorphous efflorescent salts occur in undisturbed areas and can be newly formed in large quantities in disturbed areas. As dissolution of minerals is enhanced by mining, the presence of efflorescent salts greatly increases during and after the mining process. Sediments that have accumulated salts near the surface prior to mining or in spoil piles prior to reclamation may be placed below the postmining water table following reclamation. Placement below the water table results in rapid dissolution of the salts into the ground water and greatly increases the dissolved solids. Following reclamation, salts can accumulate in large quantities in the upper portions of the reclaimed-soil profile. During spring snowmelt, the accumulated salts can be flushed rapidly through the unsaturated zone and to the reclaimed-spoil aquifer.

Cation-exchange reactions on clay minerals are present in the disturbed environment and are the primary source of sodium in the reclaimed-spoil aquifer water. However, cation exchange commonly does not remove all of the calcium and magnesium from solution, and in reclaimed-spoil aquifer water, calcium and magnesium remain the dominant cations in solution.

\section{Water Quality at the Study Sites}

Water-quality samples were collected from all wells, springs, and lysimeters at the study sites. The samples were analyzed for $\mathrm{pH}$, major constituents, and trace elements at the U.S. Geological Survey National Water Quality Laboratory in Arvada, Colorado. All samples also were analyzed for nutrients during water year 1988, but because nutrient concentrations were not detected in large quantities, their analysis was discontinued during 1989. The analytical results for $\mathrm{pH}$ and major water-quality constituents for all samples collected at all of the wells, springs, and lysimeters are summarized in table 7 . The complete chemical analyses, including trace elements and nutrients, for each water-quality sample collected during the study are available in a report by Williams and others (1992). 
Table 7. Statistical summary of pH and concentrations of selected major water-quality constituents in water samples collected at the Spring Creek, Cow Camp Creek, Zuli, and Bond Creek sites, November 1987-September 1989

[std dev, standard deviation; $\mathrm{CaCO}_{3}$, calcium carbonate]

\begin{tabular}{|c|c|c|c|c|c|c|c|c|c|}
\hline \multirow{3}{*}{$\begin{array}{l}\text { Sampling site or } \\
\text { well name }\end{array}$} & \multirow{3}{*}{$\begin{array}{c}\text { Number } \\
\text { of } \\
\text { samples }\end{array}$} & \multicolumn{8}{|c|}{$\begin{array}{l}\text { Constltuent } \\
\text { (milligrams per liter) }\end{array}$} \\
\hline & & \multicolumn{2}{|c|}{ pH } & \multicolumn{2}{|c|}{ Calcium } & \multicolumn{2}{|c|}{ Magneslum } & \multicolumn{2}{|c|}{ Sodium } \\
\hline & & Mean & Std dev & Mean & Std dev & Mean & Std dev & Mean & Std dev \\
\hline \multicolumn{10}{|c|}{ SPRING CREEK } \\
\hline SL2 & 10 & 7.6 & 0.13 & 160 & 44 & 150 & 45 & 1,100 & 110 \\
\hline SI2 & 9 & 8.0 & .10 & 38 & 8.5 & 20 & 4.8 & 650 & 34 \\
\hline SW2 & 9 & 8.3 & .18 & 8.8 & 3.5 & 2.9 & 1.3 & 520 & 93 \\
\hline SU4 & 10 & 8.1 & .17 & 50 & 24 & 23 & 15 & 860 & 33 \\
\hline SU2 & 9 & 8.8 & .21 & 6.1 & 4.7 & 2.6 & 3.1 & 330 & 30 \\
\hline SD4 & 9 & 9.1 & .19 & 1.5 & .11 & .45 & .064 & 180 & 6.7 \\
\hline S61 & 10 & 6.9 & .13 & 460 & 23 & 310 & 9.9 & 160 & 16 \\
\hline S87 (Spring) & 10 & 6.8 & .14 & 460 & 16 & 320 & 18 & 170 & 21 \\
\hline SLYS (Lysimeter) & 3 & 8.3 & .10 & 470 & 38 & 430 & 37 & 170 & 30 \\
\hline \multicolumn{10}{|c|}{ COW CAMP CREEK } \\
\hline CL2 & 9 & 7.0 & .08 & 320 & 44 & 200 & 27 & 130 & 17 \\
\hline $\mathrm{Cl} 2$ & 9 & 8.3 & .17 & 9.9 & 1.4 & 4.5 & .68 & 400 & 57 \\
\hline $\mathrm{CW} 2$ & 9 & 8.4 & .13 & 12 & 3.2 & 11 & 3.2 & 390 & 64 \\
\hline CU2 & 10 & 8.5 & .18 & 3.5 & 1.0 & .94 & .30 & 290 & 37 \\
\hline C62 & 8 & 7.0 & .09 & 380 & 36 & 220 & 19 & 140 & 31 \\
\hline C87 (Spring) & 9 & 7.1 & .16 & 360 & 27 & 220 & 17 & 130 & 22 \\
\hline CLYS (Lysimeter) & 3 & 7.9 & .21 & 460 & 46 & 310 & 10 & 53 & 2.5 \\
\hline \multicolumn{10}{|c|}{ ZULI } \\
\hline ZL2 & 9 & 8.3 & .14 & 4.8 & 1.1 & 2.2 & .76 & 530 & 13 \\
\hline ZI2 & 10 & 8.6 & .24 & 2.5 & .23 & .86 & .071 & 320 & 9.9 \\
\hline ZW2 & 4 & 8.6 & .19 & 2.7 & .36 & .87 & .22 & 300 & 14 \\
\hline ZU2 & 8 & 8.5 & .16 & 5.0 & 1.0 & 3.7 & .80 & 300 & 34 \\
\hline \multicolumn{10}{|c|}{ BOND CREEK } \\
\hline BL2 & 12 & 7.9 & .17 & 43 & 19 & 26 & 12 & 190 & 29 \\
\hline BI2 & 13 & 7.3 & .11 & 94 & 18 & 56 & 8.8 & 54 & 11 \\
\hline BW2 & 13 & 8.1 & .29 & 10 & 1.6 & 6.6 & .69 & 160 & 4.8 \\
\hline BU2 & 11 & 8.2 & .25 & 11 & 3.0 & 5.2 & 1.8 & 170 & 9.2 \\
\hline
\end{tabular}


Table 7. Statistical summary of $\mathrm{pH}$ and concentrations of selected major water-quality constituents in water samples collected at the Spring Creek, Cow Camp Creek, Zuli, and Bond Creek sites, November 1987-September 1989--Continued

\begin{tabular}{|c|c|c|c|c|c|c|c|c|}
\hline \multirow{3}{*}{$\begin{array}{l}\text { Sampling site or } \\
\text { well name }\end{array}$} & \multicolumn{8}{|c|}{$\begin{array}{l}\text { Constituent } \\
\text { (milligrams per liter) }\end{array}$} \\
\hline & \multicolumn{2}{|c|}{ Chloride } & \multicolumn{2}{|c|}{ Sulfate } & \multicolumn{2}{|c|}{$\begin{array}{l}\text { Alkalinlty } \\
\left.\text { (as } \mathrm{CaCO}_{3}\right)\end{array}$} & \multicolumn{2}{|c|}{$\begin{array}{l}\text { Dissolved solids } \\
\text { (calculated) }\end{array}$} \\
\hline & Mean & Std dev & Mean & Std dev & Mean & Std dev & Mean & Std dev \\
\hline \multicolumn{9}{|c|}{ SPRING CREEK } \\
\hline SL2 & 19 & 2.7 & 2,800 & 480 & 480 & 19 & 4,500 & 650 \\
\hline SI2 & 12 & 1.8 & 1,100 & 130 & 550 & 8.1 & 2,100 & 170 \\
\hline SW2 & 21 & 6.5 & 520 & 240 & 620 & 42 & 1,500 & 320 \\
\hline SU4 & 44 & 6.3 & 1,600 & 210 & 480 & 11 & 2,900 & 270 \\
\hline SU2 & 11 & 1.9 & 310 & 87 & 440 & 8.2 & 940 & 120 \\
\hline SD4 & 2.3 & .32 & 37 & 4.4 & 380 & 1.6 & 460 & 9.1 \\
\hline S61 & 38 & 9.7 & 2,200 & 57 & 450 & 53 & 3,500 & 87 \\
\hline S87 (Spring) & 39 & 10 & 2,300 & 95 & 460 & 30 & 3,700 & 130 \\
\hline SLYS (Lysimeter) & 12 & 2.0 & 3,000 & 150 & 170 & 87 & 4,300 & 320 \\
\hline \multicolumn{9}{|c|}{ COW CAMP CREEK } \\
\hline CL2 & 15 & 1.4 & 1,500 & 200 & 380 & 44 & 2,400 & 260 \\
\hline $\mathrm{CI} 2$ & 12 & .60 & 410 & 140 & 510 & 13 & 1,200 & 190 \\
\hline CW2 & 5.6 & 2.8 & 460 & 220 & 470 & 55 & 1,200 & 260 \\
\hline CU2 & 6.2 & 1.2 & 170 & 66 & 480 & 17 & 760 & 110 \\
\hline $\mathrm{C} 62$ & 14 & 1.8 & 1,800 & 110 & 390 & 26 & 2,800 & 140 \\
\hline C87 (Spring) & 14 & 2.6 & 1,700 & 120 & 370 & 29 & 2,700 & 130 \\
\hline CLYS (Lysimeter) & 16 & 10 & 2,400 & 100 & 130 & 47 & 3,400 & 130 \\
\hline \multicolumn{9}{|c|}{ ZULI } \\
\hline $\mathrm{ZL2}$ & 8.7 & 0.50 & 21 & 10 & 1,200 & 16 & 1,300 & 18 \\
\hline $\mathrm{ZI} 2$ & 3.9 & .24 & 76 & 8.2 & 650 & 3.7 & 810 & 12 \\
\hline ZW2 & 2.5 & .10 & 17 & 4.3 & 660 & 4.2 & 730 & 33 \\
\hline ZU2 & 2.8 & 1.3 & 46 & 17 & 640 & 70 & 750 & 89 \\
\hline \multicolumn{9}{|c|}{ BOND CREEK } \\
\hline BL2 & 5.2 & .41 & 130 & 73 & 500 & 43 & 720 & 68 \\
\hline BI2 & 5.0 & .76 & 150 & 85 & 420 & 38 & 640 & 94 \\
\hline BW2 & 2.1 & .18 & 11 & 9.6 & 390 & 5.6 & 440 & 15 \\
\hline BU2 & 3.6 & 1.2 & 60 & 22 & 370 & 6.7 & 490 & 37 \\
\hline
\end{tabular}


The chemical composition of water samples collected from the Spring Creek, Cow Camp Creek, Zuli, and Bond Creek sites in April 1988 are plotted on trilinear diagrams in figures 25 through 28 . Generally, the water quality of the samples at each site in April 1988 is indicative of the water quality at the site during the course of the study. Some time-dependent variations in the chemical characteristics of the samples were detected and are discussed in sections presented later in the report pertaining to the water quality at specific sites. The water-quality samples at the four sites vary between two distinctly different water types. Samples from wells completed in aquifers unaffected by mining are predominantly a sodium bicarbonate water type, and dissolved-solids concentrations generally range from 400 to $1,300 \mathrm{mg} / \mathrm{L}$. Samples from the Zuli and Bond Creek sites generally are of this type. Water samples collected from wells completed in the reclaimed-spoil aquifers and from springs and lysimeters associated with reclaimed-spoil material primarily are composed of calcium, magnesium, and sulfate; dissolved-solids concentrations generally range from 2,500 to $4,500 \mathrm{mg} / \mathrm{L}$. The Secondary Maximum Contaminant Level drinking water standard for dissolved solids is $500 \mathrm{mg} / \mathrm{L}$ (U.S. Environmental Protection Agency, 1990). Water from wells completed in aquifers lithologically above the Wadge coal and near the margins of the reclaimed-spoil aquifers at Spring Creek and Cow Camp Creek, in general, have an intermediate composition between the undisturbed water type and the water type associated with reclaimed-spoil material.

Evidence of mixing can be determined by a comparison of the ion concentrations in water collected from the Cow Camp Creek site (table 8). The milliequivalent calculations were based on the mean constituent concentrations reported in table 7 . For each constituent listed, the spring concentration is intermediate between the surface recharge (lysimeter) water and the underburden aquifer water.

\section{Saturation Indices}

Saturation indices (SI) may be used to indicate if a mineral will dissolve into or precipitate from solution. The activities of dissolved chemical constituents and the SI for plausible mineral sinks or sources were determined by using the U.S. Geological Survey computer program WATEQF (Plummer and others, 1976). The SI (dimensionless) is the logarithm of the ionactivity product (IAP) for a specific water sample divided by the equilibrium constant $(\mathrm{K})$ at $25^{\circ} \mathrm{C}$ for a specific mineral-water interaction:

$$
\mathrm{SI}=\log (\mathrm{IAP} / \mathrm{K})
$$

A negative SI indicates that the water is undersaturated with respect to the mineral and, if present, the mineral should dissolve. If the SI is positive, the water is supersaturated with respect to the mineral, and the mineral should precipitate from solution. An SI value at or near zero indicates a condition near equilibrium.

SI values for selected minerals are listed in table 9 for all of the water samples collected in April 1988. The results indicate that all the water samples collected at each of the sites were either saturated or near saturation with respect to calcite. In addition, a number of the samples were at or near saturation with respect to dolomite. Water samples from aquifers unaffected by mining were undersaturated with respect to sulfate minerals (gypsum and epsomite), but were at or near saturation in lysimeter, reclaimed-spoil aquifer, and spring samples from the Spring Creek and Cow Camp Creek sites. These results indicate that carbonate minerals (calcite and dolomite) tend to control the quantity and composition of dissolved solids in water unaffected by mining, and sulfate minerals are not as important. However, for water that has contacted spoil material, carbonate and sulfate minerals seem to control the quantity and composition of dissolved solids. The solubility of carbonate minerals limits the maximum dissolved-solids concentration in undisturbed aquifers. Because sulfate minerals generally are much more soluble than carbonate minerals, water in contact with spoil material, which probably contains amorphous sulfate salts, can attain much larger concentrations of dissolved solids than water unaffected by mining.

\section{Water Quality at Sites with Undisturbed Bedrock Aquifers}

Aquifers at the Zuli and Bond Creek sites were assumed to be unaffected by mining. Water samples collected from both sites were a sodium bicarbonate type, and mean dissolved-solids concentrations ranged from 440 to $1,300 \mathrm{mg} / \mathrm{L}$.

\section{Zuli Site}

Dissolved-solids concentrations at the Zuli site varied little during the study. The dissolved solids in water sampled at the Zuli site were primarily composed of sodium and bicarbonate with only small concentrations of calcium, magnesium, and sulfate (fig. 27). This type of water is indicative of undisturbed aquifers in which carbonate dissolution and precipitation and cation exchange are the controlling mineral-water reactions. 


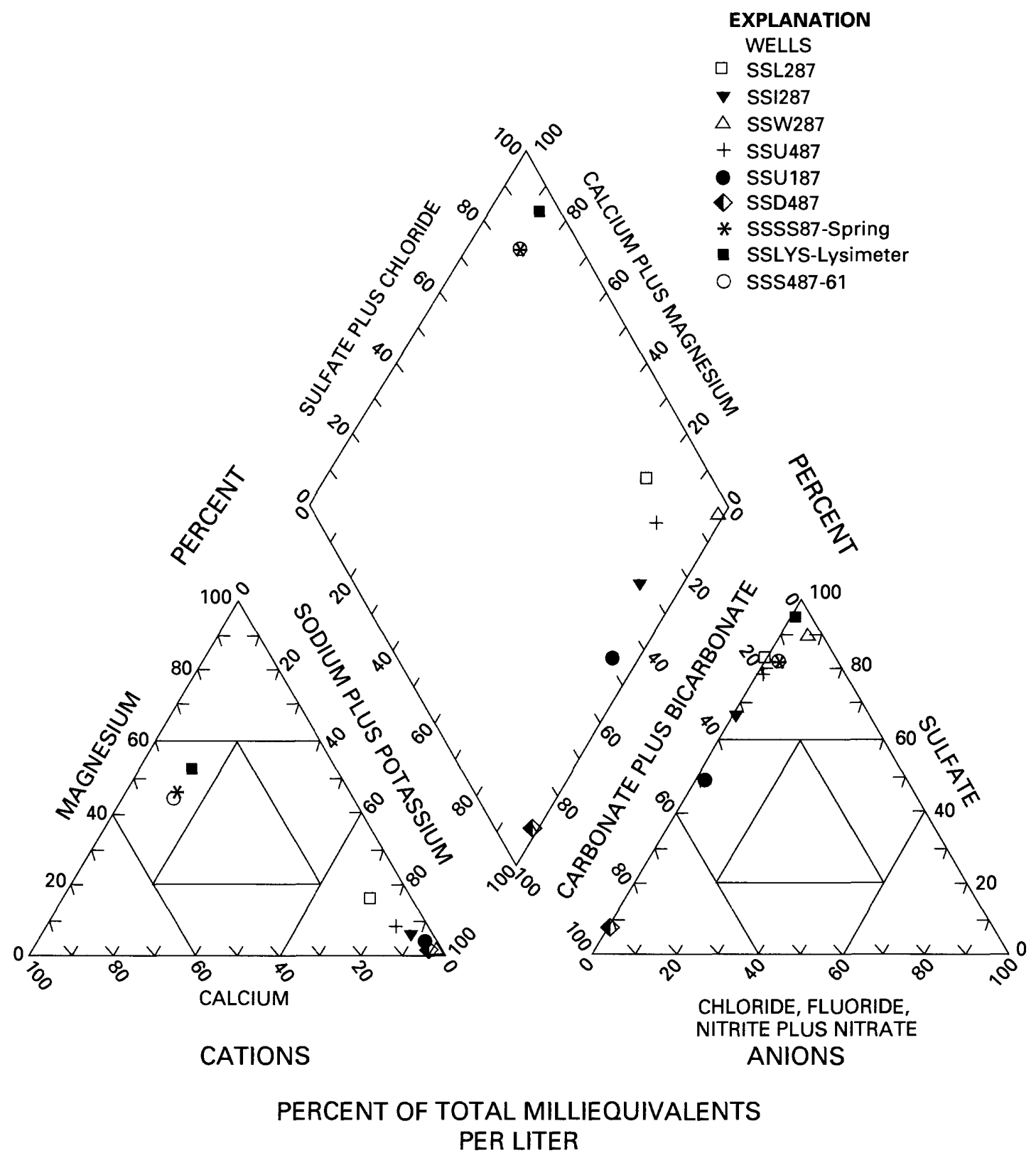

Figure 25. Chemical composition of water samples collected in April 1988 at the Spring Creek Site. 


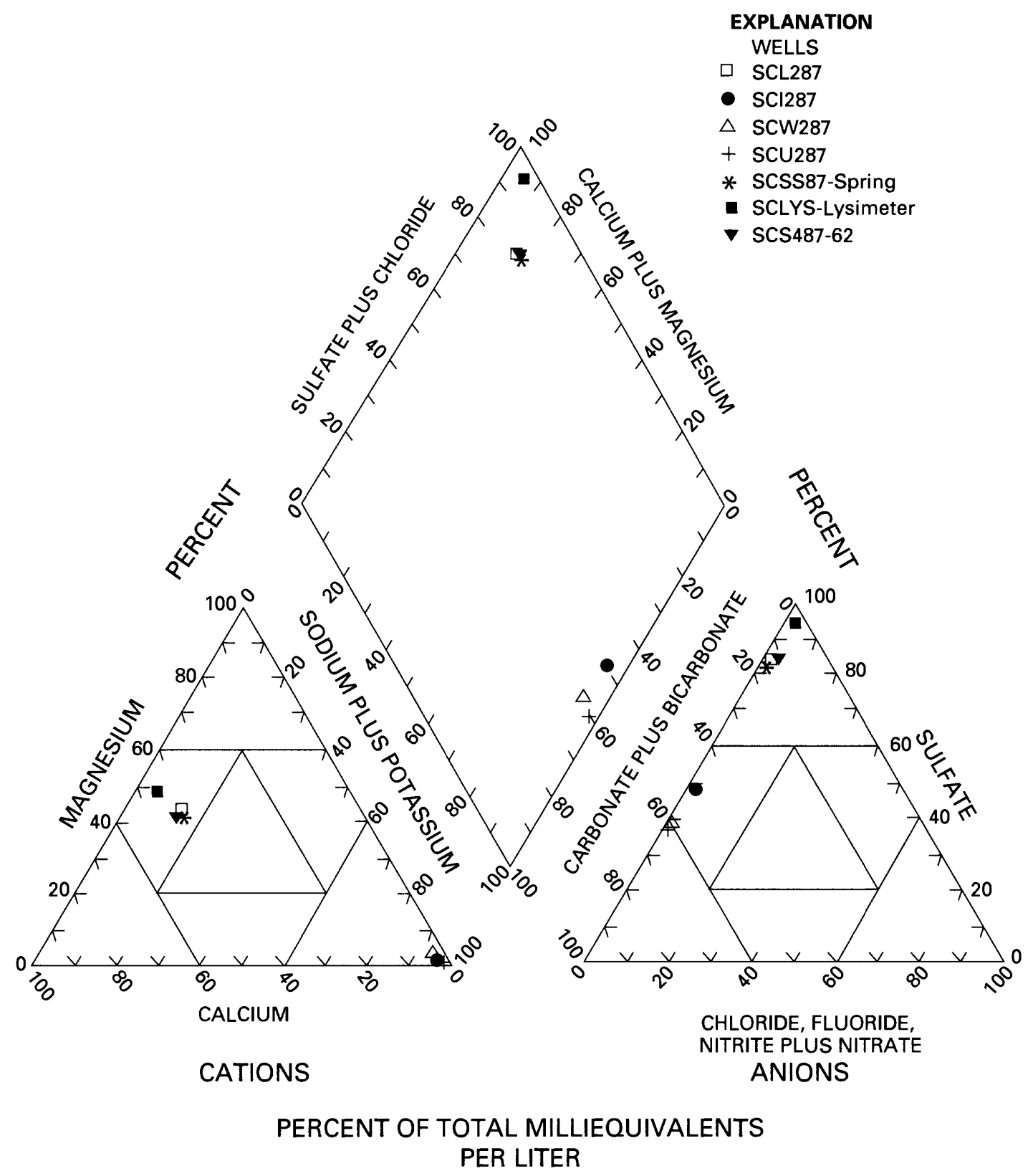

Figure 26. Chemical composition of water samples collected in April 1988 at the Cow Camp Creek site. 


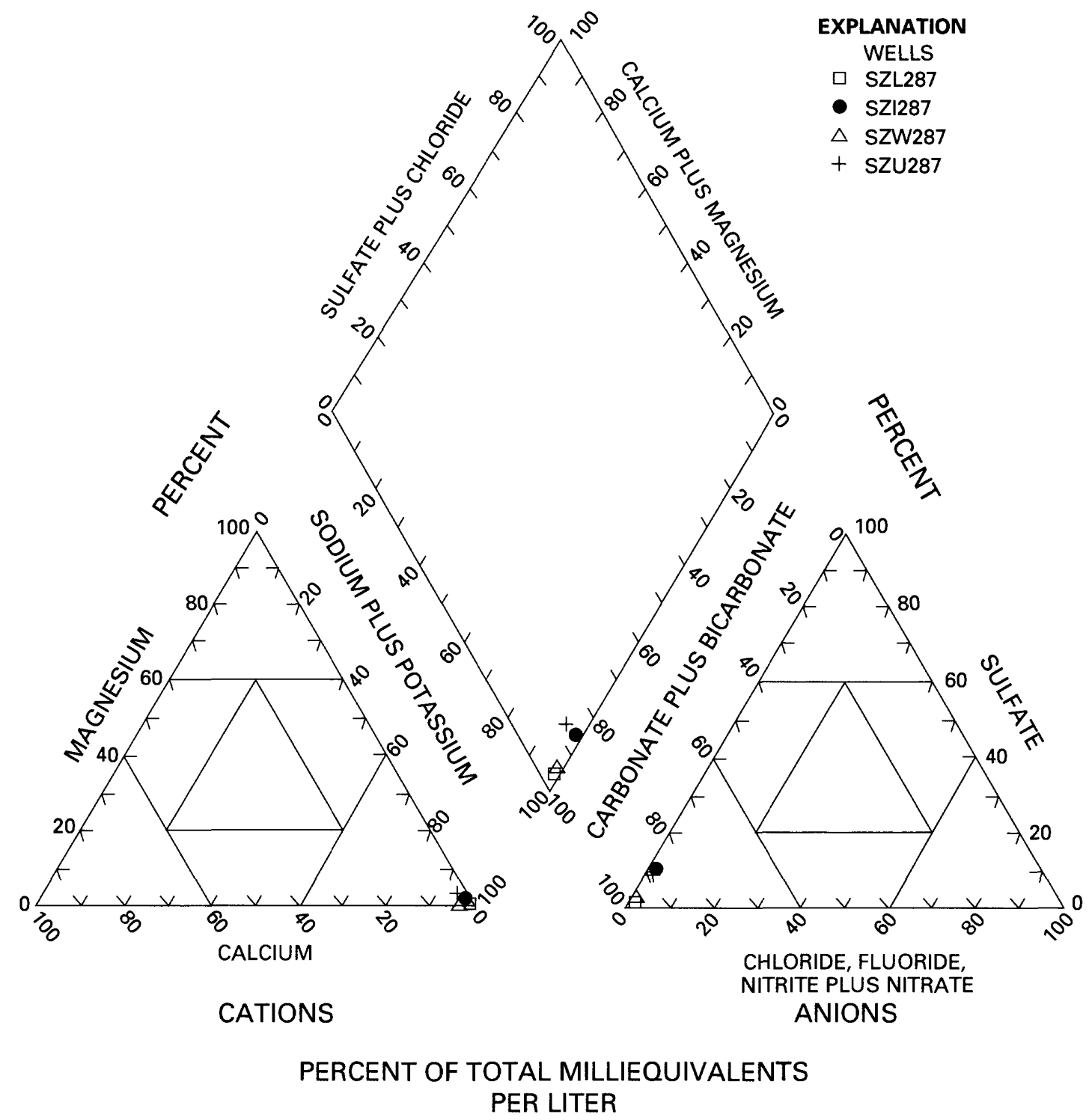

Figure 27. Chemical composition of water samples collected in April 1988 at the Zuli site. 


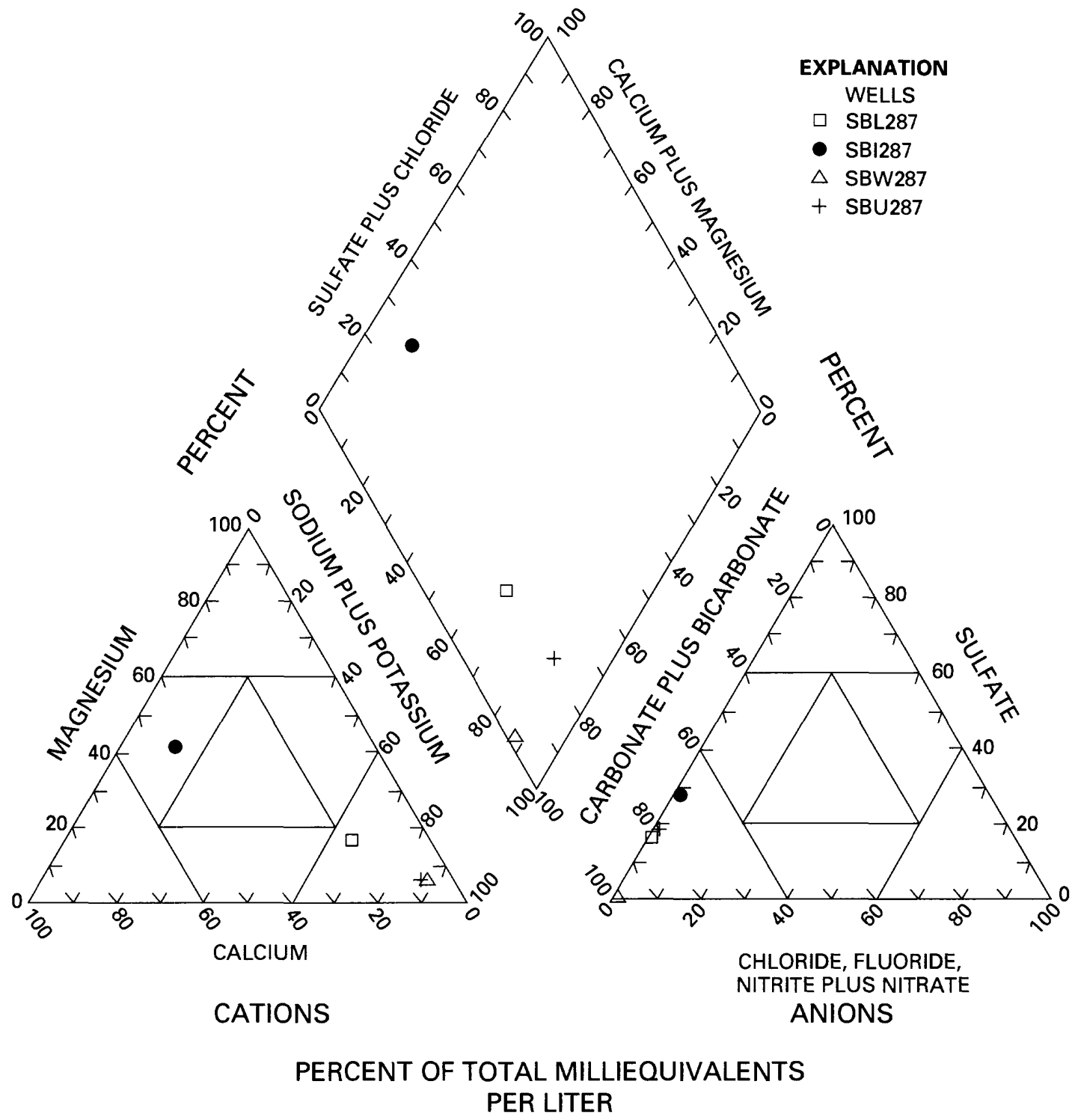

Figure 28. Chemical composition of water samples collected in April 1988 at the Bond Creek site. 
Table 8. Mean milliequivalent concentrations for selected ions from the lysimeter, the spring, the reclaimed-spoil aquifer, and the underburden aquifer at the Cow Camp Creek site

\begin{tabular}{lcccc}
\hline & $\begin{array}{c}\text { Lysim- } \\
\text { eter }\end{array}$ & Spring & $\begin{array}{c}\text { Re- } \\
\text { claimed- } \\
\text { spoll } \\
\text { aquifer }\end{array}$ & $\begin{array}{c}\text { Under- } \\
\text { burden } \\
\text { aquifer }\end{array}$ \\
\hline Calcium & 23 & 18 & 19 & 0.17 \\
Magnesium & 26 & 18 & 18 & .077 \\
Sodium & 2.3 & 5.6 & 6.1 & 13 \\
Chloride & .45 & .39 & .39 & .17 \\
Sulfate & 50 & 35 & 38 & 3.5 \\
Bicarbonate & 2.6 & 7.4 & 7.8 & 9.6 \\
\hline
\end{tabular}
table 6.

${ }^{1}$ Bicarbonate was calculated from alkalinity values reported in

\section{Bond Creek SIte}

In spring 1989, the concentrations of dissolved sulfate in water from the Lennox coal and the interburden aquifer increased substantially (fig. 29). One possible explanation for increased sulfate concentrations is the progression of mining operations upgradient from the ground-water wells (fig. 7). As the bedrock comprising the Wadge coal overburden was removed and subsequently replaced by spoil material, formation of a spoil aquifer could have begun. The newly formed spoil aquifer could then have supplied recharge water with larger concentrations of dissolved sulfate to the wells. However, at the Bond Creek site, a landslide occurred in February 1989, upgradient from the Bond Creek wells. The landslide also could have affected the water quality of the Lennox coal and interburden aquifers at the Bond Creek site. The increase in sulfate concentrations in the two aquifers could have resulted from an increase in pyrite oxidation following the introduction of oxygen to the ground water during the slide. The interburden aquifer, which has a much larger hydraulic conductivity than the surrounding lithologic units, could then have transmitted the sulfate-enriched water quickly down the general flow path. Because the vertical hydraulic gradient in the area is upward, some of the sulfate-enriched water in the interburden aquifer could have moved across a leaky confining zone and into the Lennox coal. An almost identical pattern of fluctuation of hydraulic head following the slide (fig. 30 ) could indicate a hydraulic connection between the Lennox coal aquifer and the interburden aquifer. However, the fluctuation simply might be a similar response by both aquifers to recharge.

Whether the change in dissolved-sulfate concentrations in the Lennox coal and interburden aquifers or the possible hydraulic connection between the two aquifers is the result of mining operations or the landslide is difficult to determine. Further monitoring at the Bond Creek site might be necessary to determine the exact cause of the chemical and hydraulic changes that were observed.

Water from the Wadge coal and underburden aquifers at the Bond Creek site did not seem to be affected by mining or the landslide. Water collected from these two aquifers was a sodium bicarbonate type (fig. 28) and had no increase in dissolved sulfate or dissolved solids throughout the study.

\section{Water Quality at Sites with Bedrock Aquifers and Reclaimed-Spoil Aquifers}

The Spring Creek and Cow Camp Creek sites represent areas that have been affected by mining. In most instances, water samples collected from wells completed in aquifers stratigraphically below the depth of mining are a sodium bicarbonate type similar to water samples collected at the undisturbed Zuli and Bond Creek sites. Water that was collected from reclaimed-spoil aquifers, springs, and lysimeters and that has contacted spoil material has dissolved-solids concentrations that range from 2,500 to $4,500 \mathrm{mg} / \mathrm{L}$, is predominantly a calcium magnesium sulfate type, and has only minor concentrations of sodium and bicarbonate. Water in aquifers in the flow path downgradient from the reclaimed spoil and stratigraphically above the maximum depth of mining seems to be a mixture of reclaimed spoil water and undisturbed water.

Water collects in the Spring Creek and Cow Camp Creek lysimeters only during spring snowmelt. This indicates that during the spring, the field capacities of the reclaimed spoil at the Seneca II Coal Mine are exceeded, and water percolates downward to recharge the ground water. During the other parts of the year, the lysimeters remain dry as water infiltrating the soil surface is either retained to replenish the soilwater deficit or is returned to the atmosphere through the processes of evaporation and transpiration. Therefore, the lysimeter samples represent recent snowmelt that has infiltrated the soil surface and percolated through the reclaimed-spoil profile to the depth of the lysimeter collection tank. Water samples collected in April 1988 from the Spring Creek and Cow Camp Creek lysimeters are saturated with respect to gypsum and calcite (table 9) and have large concentrations of dissolved calcium, magnesium, and sulfate. Secondary amorphous salts of calcite, gypsum, and epsomite, which have been deposited in the upper few feet of the reclaimed-spoil profile through evaporative concentration, probably dissolve rapidly in percolating water. 
Table 9. Saturation indices for selected mineral phases for water samples collected at the study sites during April 1988

[Positive index, mineral will tend to precipitate; negative index, mineral will tend to dissolve]

\begin{tabular}{|c|c|c|c|c|}
\hline \multirow{3}{*}{ Weli name } & \multicolumn{4}{|c|}{ Mineral phase } \\
\hline & \multicolumn{2}{|c|}{ Carbonate minerais } & \multicolumn{2}{|c|}{ Sulfate minerais } \\
\hline & Calclte & Dolomite & Gypsum & Epsomite \\
\hline & & NG CREEK & & \\
\hline SL2 & 0.19 & -0.15 & -0.58 & -2.72 \\
\hline SI2 & .25 & -.26 & -1.21 & -3.58 \\
\hline SW2 & -.02 & -1.38 & -2.37 & -5.34 \\
\hline SU4 & .44 & .14 & -.82 & -3.23 \\
\hline SU2 & .59 & .43 & -1.92 & -4.32 \\
\hline SD4 & .07 & -.80 & -3.72 & -6.29 \\
\hline S61 & -.03 & -.70 & -.05 & -2.36 \\
\hline $\begin{array}{l}\text { S87- } \\
\text { (Spring) }\end{array}$ & -.05 & -.72 & -.07 & -2.35 \\
\hline \multirow{2}{*}{$\begin{array}{l}\text { (Spring) } \\
\text { SLYS- (Lysimeter) }\end{array}$} & 1.43 & 2.45 & .01 & -2.16 \\
\hline & \multicolumn{3}{|c|}{ COW CAMP CREEK } & \\
\hline CL2 & .06 & -.57 & -.23 & -2.53 \\
\hline $\mathrm{CI} 2$ & .35 & -.15 & -1.97 & -4.42 \\
\hline CW2 & .42 & .35 & -2.17 & -4.26 \\
\hline CU2 & .10 & -.83 & -2.92 & -5.57 \\
\hline $\mathrm{C} 62$ & .22 & -.19 & -.17 & -2.55 \\
\hline C87- (Spring) & .05 & -.67 & -.18 & -2.49 \\
\hline \multirow[t]{2}{*}{ CLYS-(Lysimeter) } & .25 & -.23 & .01 & -2.25 \\
\hline & \multicolumn{3}{|c|}{ ZULI } & \\
\hline $\mathrm{ZL2}$ & .25 & -.31 & -3.70 & -6.14 \\
\hline ZI2 & .16 & -.61 & -3.18 & -5.72 \\
\hline $\mathrm{ZW} 2^{1}$ & .13 & -.63 & -3.65 & -6.20 \\
\hline \multirow[t]{2}{*}{ ZU2 } & .43 & .30 & -2.89 & -5.11 \\
\hline & \multicolumn{3}{|c|}{ BOND CREEK } & \\
\hline BL2 & .62 & .53 & -1.93 & -4.26 \\
\hline B12 & .26 & -.21 & -1.34 & -3.71 \\
\hline BW2 & .34 & .01 & -4.06 & -6.36 \\
\hline BU2 & .38 & -.06 & -2.39 & -4.77 \\
\hline
\end{tabular}

${ }^{1}$ The water sample was collected in April 1989.

The mineralized water then is transported vertically downward where it is collected by the lysimeter or results in recharge to the reclaimed-spoil aquifer.

\section{Spring Creek Site}

Although the water-quality characteristics of samples collected at the Spring Creek and Cow Camp Creek sites are similar, the samples from the reclaimedspoil aquifers, springs, and lysimeters at the Spring Creek site have consistently larger concentrations of dissolved calcium, magnesium, sulfate, and alkalinity than the samples collected at the Cow Camp Creek site. The larger concentrations in Spring Creek water samples probably are due to larger quantities of Lennox coal, which is spoiled rather than mined commercially at the Seneca II Coal Mine. At Cow Camp Creek, the Lennox coal cropped out much lower on the hillslope above the low wall than at Spring Creek. Consequently, smaller quantities of Lennox coal were spoiled with the overburden at Cow Camp Creek. The Lennox coal contains large quantities of pyrite which, when oxidized, probably contribute substantially to the dissolved solids in mining-affected water. Therefore, larger quantities of Lennox coal in the spoil material at the Spring Creek site probably result in larger sulfate concentrations and enhanced weathering of carbonate minerals.

Unsaturated-zone soil water collected in the lysimeter at Spring Creek and at Cow Camp Creek con- 


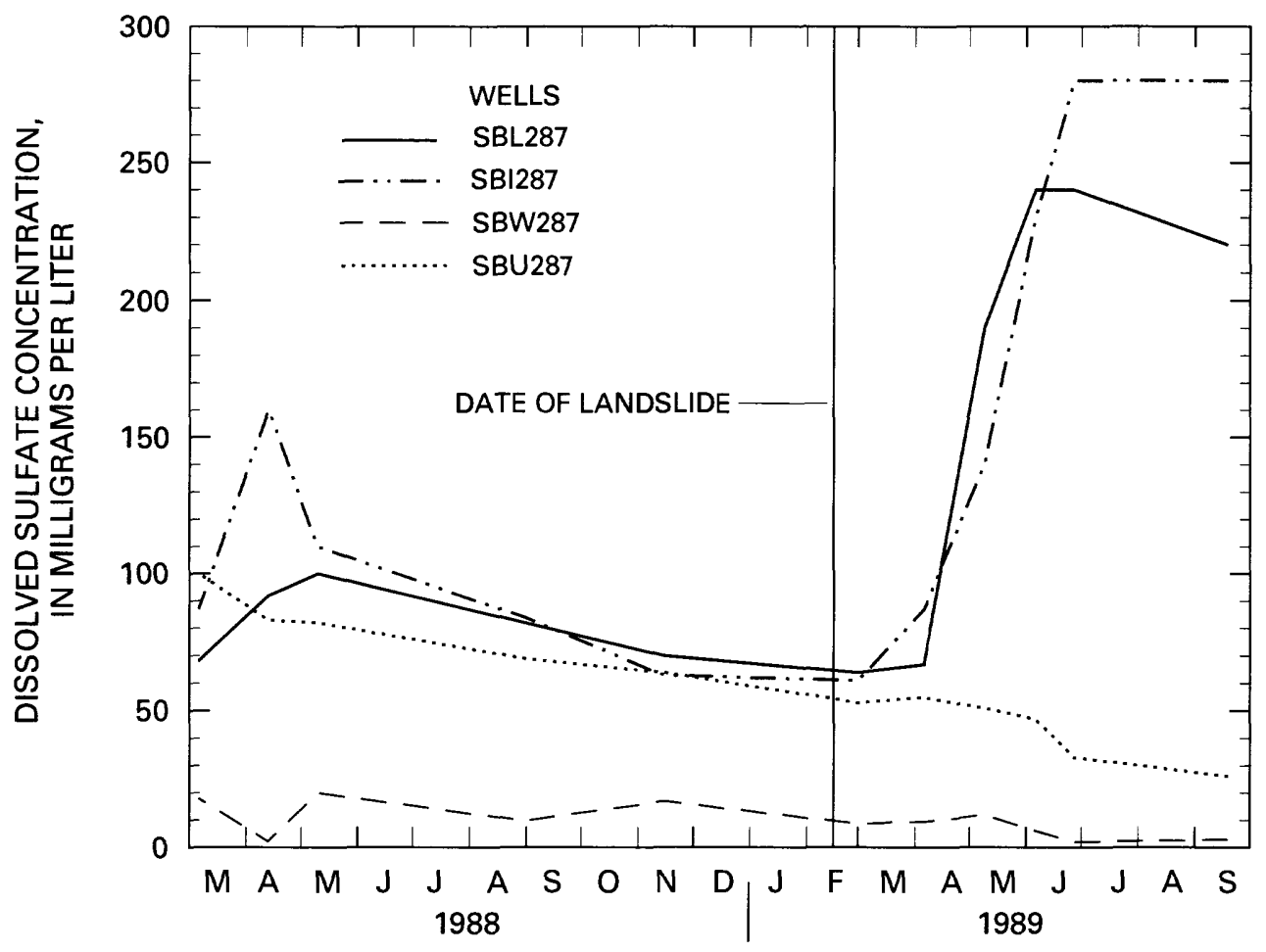

Figure 29. Dissolved-sulfate concentrations in water from wells completed in bedrock at the Bond Creek site, March 1988-September 1989.

tained larger concentrations of dissolved solids than water collected from the reclaimed-spoil aquifer. Larger concentrations in soil water as compared to reclaimed-spoil aquifer water indicate that in addition to recharge from snowmelt, reclaimed-spoil aquifers probably also receive recharge having smaller dissolved-solids concentrations from some other source, most likely the underburden aquifers.

Three wells completed in underburden were completed at Spring Creek in bedrock stratigraphically below the Wadge coal and in the flow path downgradient from the area of mining. The deepest (SSD487) was completed in a sandstone that is 84 to $98 \mathrm{ft}$ below the base of the Wadge coal. Water from well SSD487 had a mean dissolved-solids concentration of $460 \mathrm{mg} / \mathrm{L}$ and was a sodium bicarbonate type indicative of an undisturbed aquifer. The hydraulic head of SSD487 indicates the potential for upward movement of water from this deep sandstone to overlying units. A second well completed in underburden (SSU287) was completed in a sandstone from 9 to $42 \mathrm{ft}$ below the base of the Wadge coal. Water from SSU287 had larger concentrations of dissolved constituents than SSD487 but had a mean dissolved-solids concentration of less than $1,000 \mathrm{mg} / \mathrm{L}$. A couple of small coal seams present in the interval in which well SSU287 was completed probably are the source of slightly larger concentrations of dissolved sulfate in water from SSU287 as compared to SSD487. A third well completed in underburden (SSU487) was completed from 4 to $14 \mathrm{ft}$ below the base of the Wadge coal and contained water with much larger concentrations of dissolved sulfate and dissolved solids than the two other wells completed in underburden. The chemical composition of water from well SSU487 and the water level of the well (fig. 16) indicate that at least some of the water in this underburden zone could have been in contact with spoil material.

Water samples from wells completed in the Wadge coal, the interburden, and the Lennox coal at Spring Creek contain water with substantial quantities of dissolved solids. All three zones, which have slightly smaller hydraulic heads than the reclaimedspoil aquifer (fig. 16), probably receive some recharge from the reclaimed-spoil aquifer through the low wall. Water from the Lennox coal contains larger concentrations of dissolved sodium, sulfate, and dissolved solids than water from the reclaimed-spoil aquifer at Spring Creek and from the Lennox coal aquifers at the undisturbed Zuli and prelandslide Bond Creek sites. These 


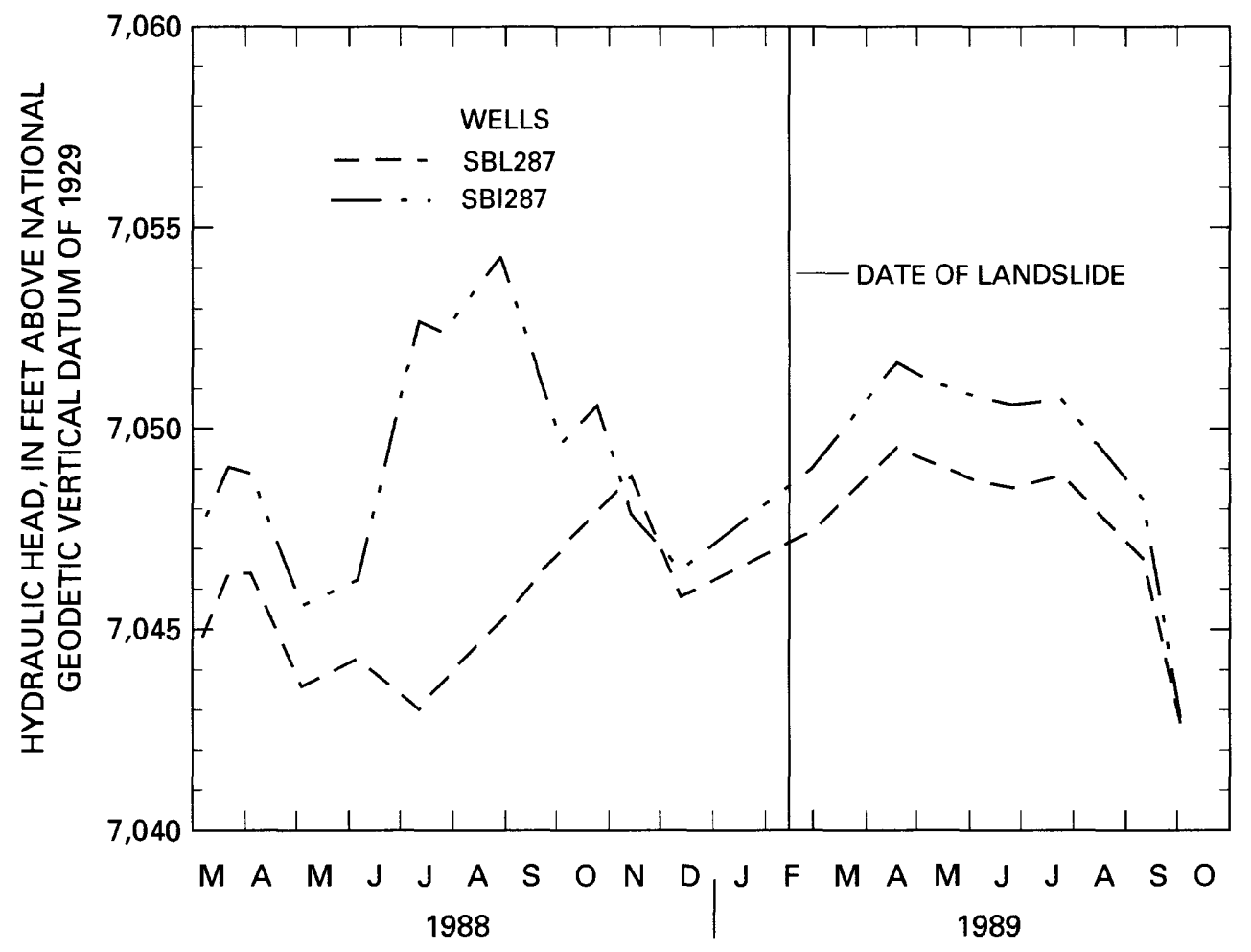

Figure 30. Hydraulic head for wells completed in the Lennox coal (SBL287) and interburden (SBI287) at the Bond Creek site, March 1988-October 1989.

larger concentrations may have resulted from movement of oxygenated spoil water into the pyritic Lennox coal seam. Oxidation of pyrite in the coal could have increased the dissolved-sulfate concentration, and cation exchange removed calcium and magnesium from solution in exchange for sodium.

\section{Cow Camp Creek Site}

The bedrock wells at the Cow Camp Creek site contain water that ranges from a sodium bicarbonate type that has dissolved-solids concentrations of less than $800 \mathrm{mg} / \mathrm{L}$ to a calcium magnesium sulfate type that has dissolved-solids concentrations exceeding $2,000 \mathrm{mg} / \mathrm{L}$. The underburden aquifer contains water that is a sodium bicarbonate type indicative of an aquifer that is undisturbed by the effects of mining. However, the mean dissolved-sulfate concentration in water from the Cow Camp Creek underburden $(170 \mathrm{mg} / \mathrm{L})$ is larger than the mean sulfate concentrations in underburden water at the Zuli and Bond Creek sites (46 and $60 \mathrm{mg} / \mathrm{L}$ ). The Cow Camp Creek underburden may contain some sulfate-enriched water that has contacted spoil.
Water from the Wadge coal and interburden aquifers at Cow Camp Creek contains larger concentrations of dissolved solids and dissolved sulfate than water from the underburden. Dissolved-sulfate concentrations in water from the Wadge coal (SCW287) and interburden (SCI287) increased steadily during the study (fig. 31). The increase in sulfate concentrations could have been caused by movement of a plume of water from the reclaimed-spoil aquifer into the Wadge coal and interburden aquifers.

Water-quality characteristics and aquifer tests indicate that the Lennox coal at the Cow Camp Creek site might be hydraulically connected with the reclaimed-spoil aquifer through a fracture or series of fractures. Not only are the composition and quantity of dissolved constituents in water from the two aquifers similar, but seasonal fluctuations in their chemical composition, particularly sulfate, also followed a similar pattern of change through the course of the study (fig. 31). The hydraulic conductivity of the Lennox coal and the reclaimed spoil is about the same value at Cow Camp Creek site (table 4). Flow between the units should not be restricted by differences in hydraulic conductivity. Aquifer tests indicate a hydraulic conductivity more than two orders of magnitude larger in 


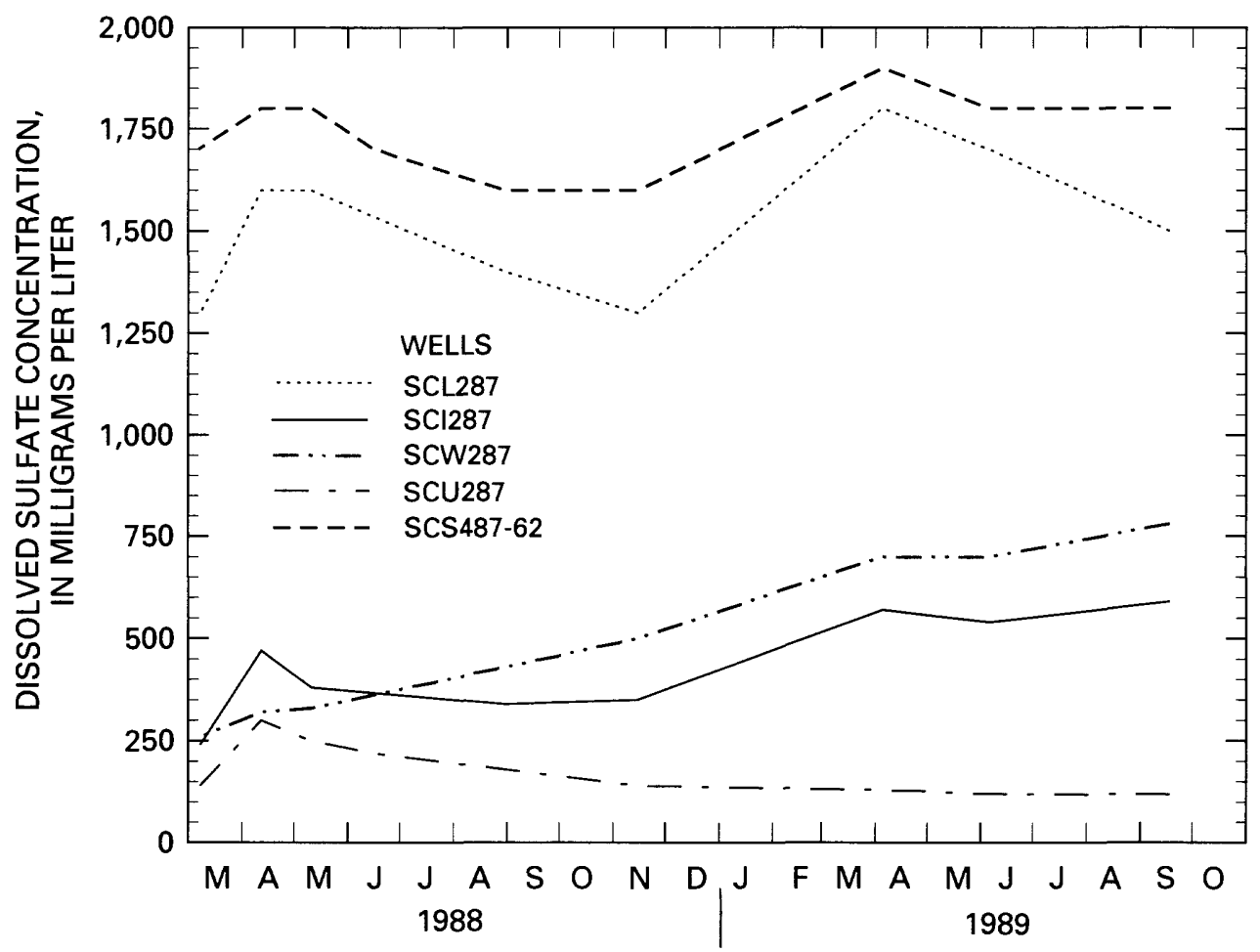

Figure 31. Dissolved-sulfate concentrations in water from wells completed in bedrock or reclaimed spoil at the Cow Camp Creek site, March 1988-September 1989.

the Lennox coal at Cow Camp Creek as compared to the Lennox coal at any of the other sites. Mining operations or natural fracturing might be responsible for a large amount of secondary permeability in the coal, thus enabling water to move rapidly from the reclaimed-spoil aquifer into the Lennox coal and down the ground-water flow path.

\section{Use of Isotopes to Characterize Recharge and Ground-Water Flow}

Isotopes of hydrogen (tritium and deuterium) and oxygen (oxygen-18) were included in the analyses of water samples from selected wells, springs, and lysimeters to help determine sources of recharge to the reclaimed-spoil aquifer. The isotope samples were collected from wells completed in the Wadge coal (excluding the Zuli site) and the underburden aquifer(s) at all sites and from the reclaimed-spoil aquifer, springs, and lysimeters at the Spring Creek and Cow Camp Creek sites. The Zuli and Bond Creek isotope samples were used to establish the isotopic composition of water from areas unaffected by mining. Tritium concentrations and deuterium, and oxygen-18 isotope ratios in selected water samples collected in April and May 1988 are listed in table 10.

The presence of detectable tritium (greater than 5.7 $\mathrm{PCi} / \mathrm{L}$ ) in a water sample (table 10 ) indicates that the sample contains at least some relatively recent (post-1952) recharge (Eriksson, 1985). Tritium concentrations in water collected at the mine ranged from less than the detection limit of 5.7 $\mathrm{PCi} / \mathrm{L}$ in a number of bedrock wells to more than $45 \mathrm{PCi} / \mathrm{L}$ in the reclaimedspoil aquifers, springs, and lysimeters. Samples collected in April and May 1988 from the undisturbed Zuli and Bond Creek sites and from three of four bedrock wells at Spring Creek indicate no recent recharge water. Water from the wells that contained no detectable tritium were a sodium bicarbonate type and probably entered the ground-water system at the top of the Tow Creek anticline prior to 1952 . Tritium concentrations in water collected from the reclaimed-spoil aquifers, springs, and lysimeters indicate some recent recharge. Tritium in water from one of the underburden wells at Spring Creek (SSU487) and from the underburden well at Cow Camp Creek also indicates some recent recharge. Tritium in water collected from the lysimeters represents concentrations in snowmelt that recharge the reclaimed-spoil aquifers, while tritium in 
the underburden aquifers represents concentrations in water that potentially recharge the reclaimed-spoil aquifer from the underburden.

Table 10. Isotope ratio analyses from water samples collected at the study sites during April and May 1988, relative to an arbitrary standard known as standard mean ocean water

[PCi/L, picocuries per liter; per mil, concentration in parts per thousand relative to a standard concentration; $<$, less than; --, no data]

\begin{tabular}{|c|c|c|c|}
\hline \multirow[b]{3}{*}{$\begin{array}{l}\text { Sampling site } \\
\text { or well name }\end{array}$} & \multicolumn{3}{|c|}{ Isotope } \\
\hline & Tritlum & Deuterium & Oxygen \\
\hline & (PCiL) & $\begin{array}{c}{ }^{2} \mathrm{H}^{\prime} \mathbf{H} \\
\text { (isotope } \\
\text { ratlo per } \\
\text { mil) }\end{array}$ & $\begin{array}{l}{ }^{18} \mathrm{O} / /^{16} \mathrm{O} \\
\text { (isotope } \\
\text { ratlo per } \\
\text { mil) }\end{array}$ \\
\hline \multicolumn{4}{|c|}{ SPRING CREEK } \\
\hline SW2 & $<5.7$ & -148 & -19.5 \\
\hline SU4 & 26 & -142 & -18.2 \\
\hline SU2 & $<5.7$ & -144 & -18.9 \\
\hline SD4 & $<5.7$ & -142 & -18.7 \\
\hline S61 & 57 & -135 & -17.6 \\
\hline S87-(Spring) & 47 & -136 & -17.7 \\
\hline $\begin{array}{l}\text { SLYS- } \\
\text { (Lysimeter) }\end{array}$ & 59 & -129 & -17.2 \\
\hline \multicolumn{4}{|c|}{ COW CAMP CREEK } \\
\hline $\mathrm{CW} 2$ & -- & -142 & -18.8 \\
\hline CU2 & 18 & -142 & -18.8 \\
\hline C62 & 45 & -135 & -17.7 \\
\hline C87-(Spring) & 55 & -137 & -17.8 \\
\hline $\begin{array}{l}\text { CLYS- } \\
\text { (Lysimeter) }\end{array}$ & 48 & -127 & -16.3 \\
\hline \multicolumn{4}{|c|}{ ZULI } \\
\hline ZU2 & $<5.7$ & -149 & -19.7 \\
\hline \multicolumn{4}{|c|}{ BOND CREEK } \\
\hline BW2 & $<5.7$ & -151 & -20.3 \\
\hline BU2 & $<5.7$ & -152 & -20.0 \\
\hline
\end{tabular}

On the basis of tritium concentrations in water from the reclaimed-spoil aquifers, the lysimeters, and the underburden aquifers, recharge to the reclaimedspoil aquifer seems to be derived primarily from recent recharge. However, large seasonal variations in tritium concentrations in precipitation and the lack of precision inherent with the laboratory analysis make it difficult to use tritium to establish mixing relations. Therefore, tritium primarily is useful for simply establishing the presence or absence of recent recharge water.

The isotopes of deuterium $\left({ }^{2} \mathrm{H}\right)$ and oxygen-18 $\left({ }^{18} \mathrm{O}\right)$ are useful for determining relative percentages of mixing in water derived from two different sources (Muir and Coplen, 1981). The isotopes are stable and do not decay over time like tritium. In addition, deuterium and oxygen-18 react conservatively in lowtemperature ground-water systems and are virtually unaffected by chemical processes. The isotopes of deuterium and oxygen-18 when compared to the more abundant isotopes of hydrogen and oxygen-16 in a specific water sample provide an isotopic ratio that can be reported relative to a standard ratio as delta values in units of per mil. A water sample with a positive delta value indicates enrichment with the heavy isotope relative to the standard, and a negative delta value indicates depletion of the heavy isotope. Isotopic ratios in water samples collected at the study sites in April and May 1988 are listed in table 10. The isotopic ratios of deuterium and oxygen-18 in the water samples are compared to precipitation from North America as reported by Gat (1980) (fig. 32). The North American continental precipitation line in figure 32 represents the isotopic composition of water samples from North America having normal isotopic fractionation (precipitation of water vapor from clouds). Water samples that have been subjected to evaporative processes or have undergone heating in geothermal systems can deviate from the line.

Mixing lines also can be plotted using the isotopes of deuterium and oxygen-18 (fig. 32). The end points of the mixing line represent source waters, and points along the line can represent mixtures of the source waters. Water samples from wells at Zuli and Bond Creek are the most depleted (have the largest negative values) in the heavy deuterium and oxygen-18 isotopes and plot toward the lower left-hand corner of the graph (fig. 32). The isotopic ratios in aquifer water at Zuli and Bond Creek represent ratios in water undisturbed by mining, and because these wells are the farthest from the source of natural recharge (the top of the anticline), they probably represent the oldest water sampled at the mine. Samples from bedrock wells completed in the Wadge coal and underburden at Spring Creek and Cow Camp Creek are more enriched in deuterium and oxygen-18 than at Zuli and Bond Creek and, therefore, have larger isotopic ratios and plot farther up and to the right of the graph (fig. 32). Water from the lysimeter is the most enriched and represents a probable source water. Water from the reclaimed-spoil aquifers and springs at Spring Creek and Cow Camp Creek are more enriched in deuterium and oxygen-18 than water from the bedrock wells; however, they are less enriched than the lysimeter water. The relations between the stable-isotope composition of these samples indicate potential mixing of bedrock-aquifer water and lysimeter water in the 


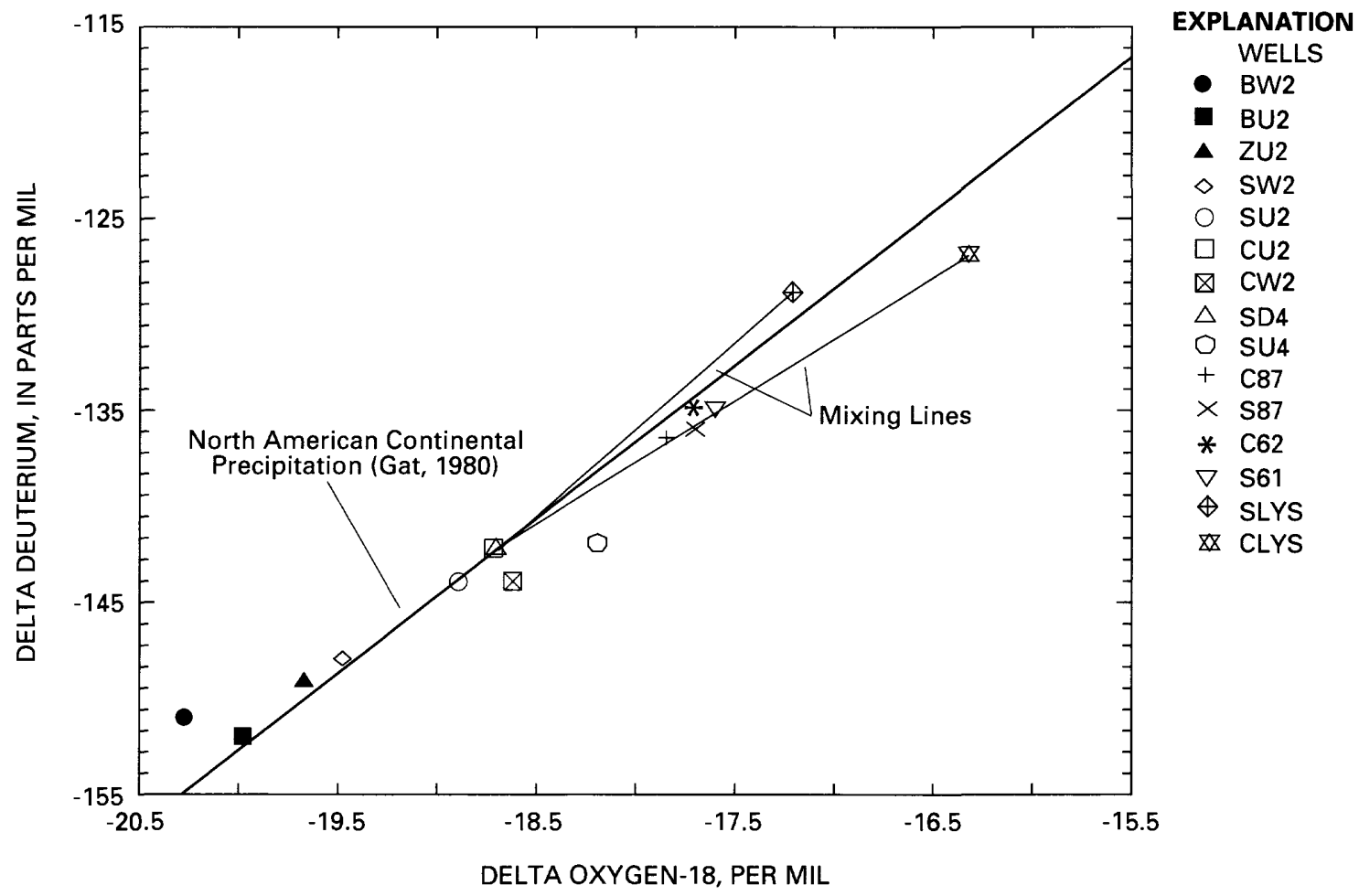

Flgure 32. Relation between delta oxygen-18 and delta deuterium for water from springs, lysimeters, and wells completed in bedrock or reclaimed spoil at the study area, April-May 1988.

reclaimed-spoil aquifer. This mixing relation seems to be applicable to the Spring Creek and Cow Camp Creek sites where water from the reclaimed-spoil aquifers and springs plot on or close to their respective mixing lines between lysimeter and underburden-aquifer water.

Mixing calculations can be used to determine the approximate contribution from each source water. Mixing calculations were done by using the isotopic ratios listed in table 10. At Spring Creek and Cow Camp Creek, ratios from the deepest underburden aquifer, the reclaimed-spoil aquifer, the spring, and the lysimeter were used for calculations. At Spring Creek, mixing calculations indicate that 45 to 65 percent of recharge to the reclaimed-spoil aquifer is from surface recharge (lysimeter water) and 35 to 55 percent is from the underburden aquifer. At Cow Camp Creek, mixing calculations indicate that 35 to 50 percent of recharge to the reclaimed-spoil aquifer is from surface recharge (lysimeter water) and 50 to 65 percent is from the underburden aquifer. Concentrations of tritium and stable-isotope ratios in water samples collected in August 1988 and in April 1989 had values similar to those in water samples collected in April and May 1988 (Williams and others, 1992). In general, surface recharge and the underburden aquifers each contribute about 50 percent of the water to the reclaimed spoil aquifers.

\section{Geochemical Reaction Simulations}

The degree of mineral-water interaction that occurs as ground water flows in the undisturbed bedrock aquifers and in the areas affected by mining at the Seneca II Coal Mine were quantified by using the U.S. Geological Survey computer program BALANCE (Parkhurst and others, 1982). The program, given the solution composition at two points along a flow path and a set of mineral, gas, or reaction phases, calculates sets of product phases and the amount of each product phase entering or leaving solution, which account for the changes in solution composition between the two points. The general equation is

Initial solution composition + Reactant phases --> End-point solution composition + Product phases

BALANCE also can be used to simulate mixing of two types of water to produce a mixed end-point 
solution composition. A general equation for this reaction is

$$
\begin{gathered}
\sigma_{1}(\text { Initial solution } 1)+\sigma_{2}(\text { Initial solution } 2)+ \\
\text { Reactant phases--> End-point solution composition + } \\
\text { Product phases }
\end{gathered}
$$

where

$\sigma_{1}$ and $\sigma_{2}$ represent the relative contributions to the end-point solution composition.

Major-ion and selected trace-element concentrations from water samples collected in April 1988 were used for initial and end-point solution compositions. Results from X-ray diffraction analysis on core samples collected from the Cow Camp Creek site and presented in the batch-mixing experiment section were used to select the mineral, gas, and reaction phases used in the simulations. Saturation indices (table 9) for the water samples used in the simulations were used to constrain the simulation results.

\section{Simulation of Recharge and Water Movement in Undisturbed Bedrock Aquifers}

The geochemical reactions that occur when snowmelt infiltrates the soil surface and percolates through undisturbed aquifer material were simulated by using BALANCE. Infiltrating snowmelt was used as the initial solution composition. Although snowmelt water has a finite chemical composition, the water was assumed to be free of dissolved solids for the purposes of the simulations. The dissolved-solids composition in water collected in April 1988 from the Bond Creek underburden aquifer was assumed to represent the dissolved-solids composition in water from an undisturbed aquifer and, therefore, was used as the end-point solution composition.

BALANCE formulates several sets of mineralwater interactions that can produce the end-point solution composition of the water sample, in this instance, the Bond Creek underburden aquifer water. However, many of the formulated interaction sets are not consistent with saturation indices calculated using WATEQF (table 9). In evaluating the evolution of Bond Creek underburden aquifer water, a number of feasible simulations were determined. However, only minimal differences existed among the feasible simulations. Therefore, the set of mineral-water interactions listed in table 11 to depict the evolution of Bond Creek underburden water is considered to be representative. The simulation result in table 11 indicates that dissolution of $\mathrm{CO}_{2}$ gas and dolomite and cation-exchange reactions are the primary mechanisms whereby water in the Bond Creek underburden aquifer obtains dissolved constituents. Precipitation of calcite limits the quantity of calcium and carbonate ions dissolved in solution. Other minerals probably contribute only minimally to the dissolved-solids concentrations in the underburden aquifer. The simulation results (table 11) for Bond Creek underburden water probably is indicative of the chemical evolution of water in most of the bedrock aquifers of Upper Cretaceous age that have not been disturbed by mining.

Table 11. Results of mass-balance simulation for recharge and ground-water movement in an undisturbed aquifer using precipitation as the initial solution composition and Bond Creek underburden aquifer water as the end-point solution composition

[Values are in millimoles per kilogram of water; a positive value indicates dissolution of the phase; a negative value indicates formation of the phase; Am., amorphous]

\begin{tabular}{lc}
\hline Mineral phase & Reaction simulation \\
\hline Calcite & -2.1640 \\
Dolomite & 2.9790 \\
Gypsum & .6650 \\
Potassium feldspar & .0900 \\
Halite & .1360 \\
Pyrite & .1000 \\
Am. iron hydroxide & -.1000 \\
Carbon dioxide & 3.7180 \\
Oxygen & .3750 \\
Cation exchange & 3.8500 \\
\hline
\end{tabular}

\section{Simulation of Recharge and Mixing in Reclaimed- Spoil Aquifers}

The geochemical reactions that occur as water moves into and through a system that has been disturbed by mining also were simulated using BALANCE. Three different sets of simulations were formulated to represent geochemical reactions in the reclaimed spoil. The first set (table 12) was developed to represent reactions during shallow recharge and percolation of recent snowmelt through the upper $8 \mathrm{ft}$ of the soil profile to the depth of the lysimeter. For this simulation, snowmelt water chemistry (assumed to be free of dissolved solids) was used as the initial solution composition, and the water chemistry of the Cow Camp Creek lysimeter was used as the end-point solution composition. The second and third sets of simulations, one for Spring Creek (table 13) and one for Cow Camp Creek (table 14), also were developed to represent mixing of sources of recharge to the reclaimedspoil aquifers; the sources were soil water from recent 
Table 12. Results of mass-balance simulation for shallow recharge at the Cow Camp Creek site using snowmelt as the initial solution composition and lysimeter water as the end-point solution composition

[Values are in millimoles per kilogram of water; a positive value indicates dissolution of the phase; a negative value indicates formation of the phase; -- indicates that the phase was not used in the simulation; Am., amorphous]

\begin{tabular}{lccc}
\hline \multirow{2}{*}{ Mineral phase } & \multicolumn{3}{c}{ Reaction simulation } \\
\cline { 2 - 4 } & $\mathbf{1}$ & $\mathbf{2}$ & $\mathbf{3}$ \\
\hline Calcite & 1.7400 & -0.7700 & -0.2500 \\
Dolomite & - & .9450 & .5000 \\
Gypsum & 10.4500 & 12.5038 & 12.3000 \\
Epsomite & 13.2100 & 12.6738 & 13.0700 \\
Plagioclase & 2.3400 & -- & .2700 \\
Potassium feldspar & .3100 & .3100 & .3100 \\
Kaolinite & -- & -- & -.3900 \\
Am. silica & -3.6400 & -.3650 & - \\
Halite & .6800 & .6800 & .6800 \\
Pyrite & 1.2300 & .4712 & .1900 \\
Am. iron hydroxide & -1.2300 & -.4712 & -.1900 \\
Oxygen & 4.6125 & 1.7670 & .7125 \\
Carbon dioxide & .1500 & .7700 & 1.1400 \\
Cation exchange & -- & .8175 & .7300 \\
\hline
\end{tabular}

Table 13. Results of mass-balance simulation for mixing of soil water and underburden aquifer water to form the reclaimed-spoil aquifer water at Spring Creek using water from the lysimeter and the deep underburden aquifer as initial solution compositions and water from the Spring Creek spring as the end-point solution composition

[Values are in millimoles per kilogram of water; a positive value indicates dissolution of the phase; a negative value indicates formation of the phase; -- indicates phase not used in the reaction simulation; Am., amorphous]

\begin{tabular}{lcc}
\hline \multirow{2}{*}{ Relative contribution or mineral phase } & \multicolumn{2}{c}{ Reaction simulation } \\
\cline { 2 - 3 } \multicolumn{1}{c}{ Contribution from soil water } & $\mathbf{1}$ & $\mathbf{2}$ \\
\hline \multicolumn{1}{c}{ Contribution from the underburden aquifer } & $\mathbf{0 . 5 9}$ & $\mathbf{0 . 5 2}$ \\
\hline Calcite & -0.7984 & $\mathbf{0 . 4 8}$ \\
Dolomite & 3.0200 & -0.2250 \\
Gypsum & .7000 & 2.9582 \\
Potassium feldspar & .0428 & 1.9773 \\
Halite & .5332 & .0616 \\
Pyrite & 1.7702 & .5547 \\
Am. iron hydroxide & -1.7702 & 2.2041 \\
Carbon dioxide & .6000 & -2.2041 \\
Oxygen & 6.6382 & - \\
Cation exchange & .9754 & 8.2654 \\
\hline
\end{tabular}


Table 14. Results of mass-balance simulation for mixing of soil water and underburden aquifer water to form the reclaimed-spoil aquifer water at Cow Camp Creek using water from the lysimeter and the underburden aquifer as initial solution compositions and water from the Cow Camp Creek spring as the end-point solution composition

[Values are in millimoles per kilogram of water; a positive value indicates dissolution of the phase; a negative value indicates formation of the phase; -- indicates phase not used in the reaction simulation; Am., amorphous]

\begin{tabular}{lcc}
\hline \multirow{2}{*}{ Relative contribution or mineral phase } & \multicolumn{2}{c}{ Reaction simulation } \\
\cline { 2 - 3 } \multicolumn{1}{c}{ Contrlbution from soll water } & $\mathbf{0 . 4 2}$ & $\mathbf{0 . 5 0}$ \\
\hline Contribution from the underburden aquifer & $\mathbf{0 . 5 8}$ & $\mathbf{0 . 5 0}$ \\
\hline Calcite & -0.5525 & -0.6900 \\
Dolomite & .8012 & 1.1567 \\
Gypsum & 2.8000 & 1.8222 \\
Epsomite & 1.7142 & .5186 \\
Plagioclase feldspar & -- & .0266 \\
Potassium feldspar & .0211 & -- \\
Halite & .0064 & -.0344 \\
Pyrite & .2500 & .3450 \\
Am. iron hydroxide & -.2500 & -.3450 \\
Carbon dioxide & .8578 & .9218 \\
Oxygen & .9380 & 1.2938 \\
Cation exchange & 2.0032 & 1.4147 \\
\hline
\end{tabular}

snowmelt and water from the underburden aquifer. For these simulations, the dissolved-solids composition of water collected from the Spring Creek and Cow Camp Creek lysimeters and the Spring Creek deep underburden and Cow Camp Creek underburden aquifer were used as the initial solution compositions, and the dissolved-solids composition of water from the Spring Creek and Cow Camp Creek springs were used as the mixed end-point solution compositions.

Results for the simulation of shallow recharge to the lysimeter (table 12) indicate that amorphous efflorescent sulfate salts of gypsum and epsomite, which are probably concentrated in the upper few feet of the soil profile, account for most of the dissolved solids in the lysimeter water. When snowmelt water percolates through the soil profile, salts present in the reclaimed spoil dissolve rapidly and are transported to the water table. This flush of dissolved solids through the reclaimed spoil probably happens only during the spring when the snowpack melts and the field capacity of the spoil material is exceeded. When the field capacity is exceeded, percolating soil water can recharge the reclaimed-spoil aquifer. During the rest of the year, water infiltrating the reclaimed-spoil surface replenishes the soil-water deficit and then is stored or lost back to the atmosphere through evapotranspiration. The lack of deep percolation of infiltrating precipitation during most of the year is supported by the absence of water in the lysimeters during the summer, fall, and winter months. Reaction simulation 1 in table 12 indicates a fairly sizable contribution of dissolved solids from plagioclase dissolution. Generally, plagioclase only contributes small quantities of dissolved solids to ground water in rocks of Cretaceous age. Therefore, reaction simulations 2 and 3 (table 12) in combination or alone probably are more representative of the mineral-water interactions during infiltration and percolation of water in the upper $8 \mathrm{ft}$ of the reclaimed-spoil profile.

The mixing simulations in tables 13 and 14 indicate that at Spring Creek the soil water contributes a larger percentage of recharge to the reclaimed-spoil aquifer than at Cow Camp Creek. In addition, the Spring Creek simulations indicate more pyrite oxidation during mixing than at Cow Camp Creek. Larger quantities of pyrite oxidation at Spring Creek are evidenced by consistently more acidic $\mathrm{pH}$ values in the Spring Creek reclaimed-spoil aquifer and spring when compared to the reclaimed-spoil aquifer and the spring at Cow Camp Creek (table 7). 
Both of the simulations for mixing at Cow Camp Creek (table 14) probably are feasible except that reaction simulation 2 indicates the formation of a small quantity of halite. Halite is substantially undersaturated in all of the water in the study area and, therefore, would not form. However, the relatively small quantity of halite forming in reaction simulation 2 is within a range where it probably can be neglected.

Although gypsum at Spring Creek and gypsum and epsomite at Cow Camp Creek still dissolve to some extent in the mixing simulations, they do not contribute as much to the dissolved-solids concentration once recharge water percolates below the depth of the lysimeter. The decreased amount of gypsum and epsomite dissolution below the lysimeter probably is because of smaller quantities of evaporative salts below the upper few feet of the reclaimed soil profile. Precipitation of salts resulting from concentration from evapotranspiration does not occur below the root zone, and, therefore, amorphous salts probably are not in great abundance at depths greater than $6 \mathrm{ft}$. Some salts probably accumulate during weathering of spoil material in spoil piles prior to reclamation. This accumulation of salts in spoil piles probably accounts for some amorphous gypsum and epsomite below the root zone.

The mixing simulations (tables 13 and 14) indicate that the relative contributions of water recharged to the reclaimed-spoil aquifer from soil water and from the underburden aquifer are similar to the relative contributions indicated by stable-isotope analysis at the Spring Creek and Cow Camp Creek sites. Both sets of mixing simulations and stable-isotope values at both sites indicate that 35 to 65 percent of the recharge to the reclaimed-spoil aquifer comes from soil water.

\section{Batch-Mixing Experiments}

Batch-mixing experiments have been used to simulate and predict changes in ground-water quality as a result of mining operations (Davis, 1984; Davis and Dodge, 1986; Naftz, 1988). Batch-mixing experiments were used in this study to identify specific lithologic units that contain large quantities of reactable minerals. Identification of the units helps to understand the overall geochemistry of an area.

\section{Batch-Mixing Methodology}

Core samples collected from the Cow Camp Creek study site in July 1987 were used for batchmixing experiments. Core samples used for the batchmixing experiments were selected to represent distinct lithologic units stratigraphically above and below the
Wadge coal seam (fig. 33). Core subsamples from each lithologic unit used for batch mixing also were analyzed for mineralogic composition (table 15). Bulkrock and clay mineralogy was determined on the sandstone and shale samples using X-ray diffraction analysis (Jackson, 1979). The mineralogy of the Lennox coal and Wadge coal was determined using X-ray diffraction analysis of low-temperature ash (Rao and Gluskoter, 1973).

The batch-mixing experiments were done during summer 1989 by using the procedure reported by Davis (1984) and Naftz (1988). A 2:1 water-rock mixture was prepared by using core samples and deionized water (Clark and Williams, 1991). The bottles were completely filled to exclude oxygen. After being mixed for 2 hours and allowed to sit for a total contact time of 24 hours, the specific conductance of the mixtures was measured. The bottles then were resealed and allowed to sit undisturbed. After 90 days of total contact time, values of specific conductance, $\mathrm{pH}$, water temperature, and alkalinity were measured, and water samples were collected, filtered through a $0.45-\mu \mathrm{m}$ filter, and analyzed for dissolved constituents.

\section{Core-Sample Mineralogy}

Core subsamples from the lithologic units used for batch mixing were analyzed for mineralogic composition (table 15). The results of the core-sample mineralogic analysis indicate that sandstone samples primarily were composed of quartz, whereas the shale samples contained less quartz and more clay. The proportions of dolomite and feldspar minerals were relatively equal among all of the sandstone and shale samples. Pyrite was present in small quantities in most of the samples. Core samples SS01 (sandstone above the Lennox coal) and CLO2 (Lennox coal) contained large nodules of pyrite that were visually evident. Core sample CL10 (Wadge coal) had no detectable pyrite. Although sulfate salts of gypsum and epsomite were not identified in the mineralogic analysis of the sandstone and shale samples, these minerals commonly are present as secondary, amorphous, efflorescent salts and are not easily detected using X-ray diffraction. Gypsum and epsomite salts have been identified as secondary amorphous minerals in similar overburden samples at other surface coal mines in northwestern Colorado (McWhorter and others, 1975; Hounslow and others, 1978)

\section{Batch-Mixing Results}

The water quality in samples from batchmixing experiments degrades from 1 to 90 days after 

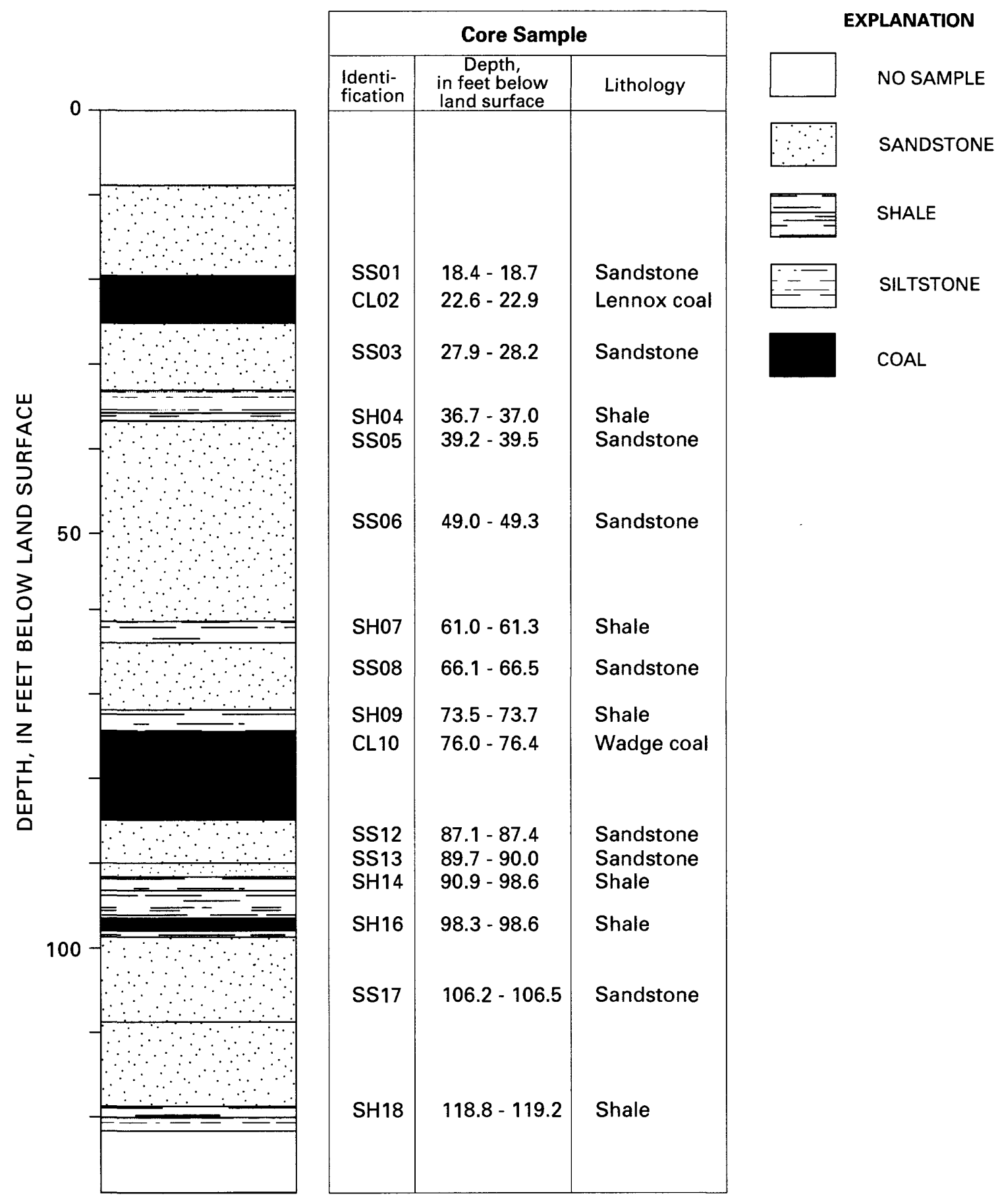

Figure 33. Lithologic units at Cow Camp Creek from which core samples were selected and used for batchmixing experiments. 
Table 15. Mineral composition of core samples from the Cow Camp Creek site for the lithologic units from which samples were used for the batch-mixing experiments, in percent by weight

[The letters in the sample identification refer to the lithologic type; SS, sandstone; SH, shale; CL, coal. The numeral represents the relative depth of the sample, 1 being the shallowest and 18 the deepest; <, less than; $\mu \mathrm{m}$, micrometer; Dol/Ank, Dolomite/Ankerite; --, none detected; tr, less than 1 percent]

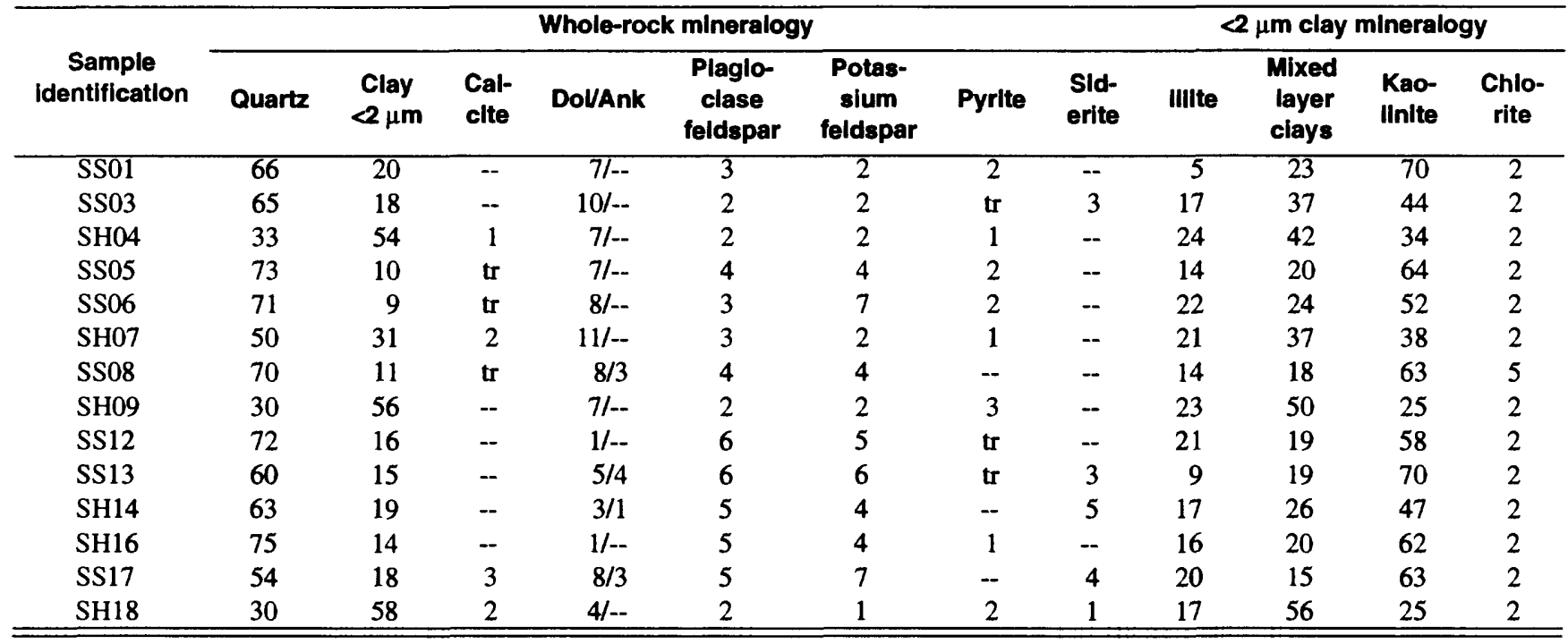

\begin{tabular}{|c|c|c|c|c|c|c|c|c|c|c|c|}
\hline \multirow{2}{*}{$\begin{array}{c}\text { Sample } \\
\text { identification }\end{array}$} & \multicolumn{3}{|c|}{$\begin{array}{l}\text { Organic, ash, and sulfur } \\
\text { content }\end{array}$} & \multicolumn{8}{|c|}{ Minerals contalned within the ash and sulfur fraction } \\
\hline & $\begin{array}{l}\text { Organic } \\
\text { content }\end{array}$ & $\begin{array}{c}\text { Ash } \\
\text { content }\end{array}$ & $\begin{array}{l}\text { Sulfur } \\
\text { content }\end{array}$ & Quartz & Dolvank & $\begin{array}{l}\text { Plaglo- } \\
\text { clase } \\
\text { feldspar }\end{array}$ & Pyrite & $\begin{array}{l}\text { Gyp- } \\
\text { sum }\end{array}$ & Barite & $\begin{array}{l}\text { Kao- } \\
\text { linite }\end{array}$ & Smectite \\
\hline CL02 & 90.5 & 6.5 & 3.0 & 1.0 & tr/-- & tr & 3.0 & tr & tr & 2.5 & $\operatorname{tr}$ \\
\hline CL10 & 91.0 & 8.5 & .5 & 3.4 & $--1--$ & 1.0 & -- & - & tr & 3.8 & $\operatorname{tr}$ \\
\hline
\end{tabular}

initial water-rock contact as evidenced by specificconductance data in table 16. The median increase in specific conductance for all 16 mixtures during the 1- to 90 -day period of contact was 329 percent. The increases ranged from 8 percent in sample SH09 to 1,250 percent in sample CL10.

The large increases in specific conductance during the 90 days of contact and the large range in the increases between different sample mixtures indicate that reactive minerals in the core samples dissolve at variable rates. Amorphous gypsum and epsomite salts dissolve rapidly when they come into contact with ground water. This rapid dissolution might account for why the shale samples, which probably contain large quantities of these salts, generally had smaller percentage increases in specific conductance from 1 day to 90 days of water-rock contact than did the sandstone and coal samples. The sandstone samples, which contain more quartz and less clay material than the shales, probably contain smaller quantities of salts and release dissolved solids more slowly upon contact with ground water. Although the extended water-rock contact period in the batch-mixing experiments might represent a worst-case condition for postmining water quality, the near equilibrium conditions for selected sulfate and carbonate minerals in the reclaimed-spoil aquifers and springs (table 9), indicate that this longer contact period might be representative of actual conditions. This time factor indicates that postmining water quality can be adequately predicted, based on batch-mixing experiments, only if the sample mixtures are allowed a sufficient period of time in which to reach a condition of mineral-water equilibrium.

The batch-mixing experiments identified three lithologic units in the Wadge coal overburden that contribute a large part of the dissolved solids present in the reclaimed-spoil aquifer (table 17). These include the sandstone above the Lennox coal (SS01), the Lennox coal (CL02), and the shale directly above the Wadge coal (SH09). Although these three units constitute only a small part of the overburden, they contain large quan- 
Table 16. Specific conductance in batch-mixing mixtures after 1 day and 90 days of water-rock contact

[The letters in the sample identification refer to the lithologic type; SS, sandstone; CL, coal; SH, shale. The numeral represents the relative depth of the sample, 1 being the shallowest and 18 the deepest; $\mu \mathrm{S} / \mathrm{cm}$, microsiemens per centimeter at 25 degrees Celsius; $\triangle \mathrm{SC}$, increase in specific conductance from 1 to 90 days after initial water-rock contact]

\begin{tabular}{|c|c|c|c|}
\hline \multirow{2}{*}{ Sample identification } & \multicolumn{2}{|c|}{$\begin{array}{l}\text { Speclfic conductance } \\
(\mu \mathrm{S} / \mathrm{cm})\end{array}$} & \multirow{2}{*}{$\begin{array}{c}\Delta \mathrm{SC} \\
\text { (percent) }\end{array}$} \\
\hline & 1 day & 90 days & \\
\hline SS01 & 1,540 & 5,950 & 286 \\
\hline CLO2 & 1,900 & 6,400 & 237 \\
\hline SS03 & 225 & 1,120 & 398 \\
\hline SHO4 & 690 & 1,180 & 71 \\
\hline SS05 & 330 & 1,410 & 327 \\
\hline SS06 & 175 & 755 & 331 \\
\hline SH07 & 450 & 985 & 119 \\
\hline SS08 & 115 & 700 & 509 \\
\hline SH09 & 3,300 & 3,560 & 8 \\
\hline CL10 & 17 & 230 & 1,250 \\
\hline SS12 & 115 & 670 & 482 \\
\hline SS13 & 90 & 862 & 858 \\
\hline SH14 & 290 & 1,380 & 376 \\
\hline SH16 & 600 & 2,430 & 305 \\
\hline SS17 & 145 & 815 & 462 \\
\hline SH18 & 510 & 1,580 & 210 \\
\hline
\end{tabular}

tities of minerals that are soluble on contact with ground water.

Samples SS01 and CL02 had large concentrations of dissolved iron and sulfate and extremely small $\mathrm{pH}$ values. The units represented by these two samples contain a large quantity of pyrite (table 15 ), which is oxidized upon contact with oxygen and water. The acid released from these two units probably has a corrosive effect on other minerals present throughout the overburden and, therefore, contributes to the dissolution of minerals in other units. Sample SH09, which represents a shale directly overlying the Wadge coal, had large concentrations of dissolved calcium, magnesium, sodium, and sulfate. This unit probably contains a large quantity of gypsum and epsomite salts that dissolve rapidly upon contact with ground water. Specific conductance increased only slightly in sample SH09 following the first day of mixing, indicating rapid dissolution of available minerals. The large concentrations of dissolved sodium in sample SH09, as in all of the shale samples, probably is derived from cationexchange reactions with clay minerals. Although other lithologic units in the overburden certainly affect the water quality of the reclaimed-spoil aquifer, the lithologic units represented by samples SSO1, CL02, and SH09 probably have the greatest effect and account for a large proportion of the dissolved constituents in the reclaimed-spoil aquifer water at Spring Creek and Cow Camp Creek.

\section{EFFECTS OF MINING}

The preceding sections contain discussions of the findings and interpretations for data collected to study the hydrology and geochemistry at the study area. The following sections of the report will integrate these components to help understand the overall system dynamics that were noted at the study sites.

Further evidence of multiple flow paths can be determined from the chemical and geochemical data from the study area. Water-quality data included major ions, trace elements, and isotopes. The data were analyzed graphically, statistically, and with models. The results of analyses indicate that the water flowing in the reclaimed-spoil aquifer and from the springs comes from underburden aquifers and snowmelt. Although the underburden water is older than the recent snowmelt water, the original source of the underburden water probably was snowmelt. The underburden water might have its origin at the mine or outside the mine boundaries.

Management and regulatory agencies and mining companies are interested in the time frame and the extent to which mining operations affect the hydrology of a mine area. To evaluate this, three questions about change need to be considered: (1) How soon does the 
Table 17. Selected properties and dissolved-constituent concentrations in batch-mixing water samples

[The letters in the sample identification refer to the lithologic type; SS, sandstone; CL, coal; SH, shale; The numeral represents the relative depth of the sample, 1 being the shallowest and 18 being the deepest. All dissolved-constituent concentrations are reported in milligrams per liter; DS, dissolved solids; $<$, less than]

\begin{tabular}{|c|c|c|c|c|c|c|c|c|c|c|c|}
\hline \multirow{2}{*}{$\begin{array}{l}\text { Sample } \\
\text { identiff- } \\
\text { cation }\end{array}$} & \multicolumn{11}{|c|}{ Property or chemical constituent } \\
\hline & $\begin{array}{c}\mathrm{pH} \\
\text { (units) }\end{array}$ & DS & $\mathrm{Ca}$ & Mg & $\mathrm{Na}$ & $\mathrm{Cl}$ & $\mathrm{SO}_{4}$ & $\mathrm{HCO}_{3}$ & $\mathrm{SiO}_{2}$ & $\mathrm{Fe}$ & Al \\
\hline SS01 & 2.58 & 8,700 & 490 & 250 & 1.6 & 0.8 & 6,100 & 0 & 110 & 1,600 & 95 \\
\hline CL02 & 1.91 & 5,100 & 30 & 14 & 30 & 3.1 & 3,900 & 0 & 14 & 1,100 & 7.9 \\
\hline $\mathrm{SS} 03$ & 7.73 & 980 & 55 & 110 & 44 & 4.6 & 340 & 430 & 3.8 & .10 & $<.001$ \\
\hline SHO4 & 7.45 & 980 & 100 & 52 & 86 & 3.2 & 520 & 200 & 10 & .11 & $<.001$ \\
\hline SS05 & 7.48 & 1,300 & 180 & 78 & 35 & 3.4 & 790 & 180 & 6.0 & .04 & $<.001$ \\
\hline SS06 & 7.88 & 610 & 65 & 42 & 33 & 2.3 & 240 & 220 & 6.2 & .03 & $<.001$ \\
\hline SH07 & 8.26 & 780 & 18 & 10 & 190 & 2.0 & 240 & 320 & 8.3 & .70 & $<.001$ \\
\hline SS08 & 8.02 & 580 & 32 & 34 & 70 & 4.3 & 120 & 320 & 4.7 & .03 & $<.001$ \\
\hline SH09 & 7.25 & 3,600 & 370 & 180 & 300 & 3.6 & 2,100 & 90 & 10 & .06 & $<.001$ \\
\hline CL10 & 7.63 & 200 & 18 & 9.0 & 19 & 1.6 & 5.0 & 140 & 2.6 & .07 & $<.001$ \\
\hline SS12 & 7.72 & 530 & 16 & 14 & 130 & 3.5 & 140 & 230 & 9.2 & .14 & $<.001$ \\
\hline SS13 & 8.13 & 730 & 19 & 12 & 160 & 2.7 & 80 & 460 & 6.0 & .07 & $<.001$ \\
\hline SH14 & 7.91 & 1,200 & 18 & 9.0 & 290 & 1.9 & 300 & 550 & 9.6 & .04 & $<.001$ \\
\hline SH16 & 3.19 & 2,100 & 150 & 44 & 260 & 3.8 & 1,500 & 0 & 140 & 160 & 5.5 \\
\hline SS17 & 7.75 & 660 & 56 & 40 & 86 & 2.6 & 240 & 240 & 120 & .20 & $<.001$ \\
\hline SH18 & 7.95 & 1,300 & 22 & 10 & 380 & 1.7 & 480 & 450 & 5.1 & .08 & $<.001$ \\
\hline
\end{tabular}

first alteration of the undisturbed system begin; (2) how fast does snowmelt water flow through the reclaimed spoil; and (3) do water quantity and water quality change seasonally?

Changes to the hydrologic system within the area to be mined begin immediately after mining begins. The changes are due to the destruction and replacement of rocks in the unsaturated and saturated zones. This destruction and replacement process results in changes in the local aquifer hydraulic properties and alterations of onsite water quality.

A fortuitous example to answer question 1, "How soon do alterations begin?" was documented at the Bond Creek site. Whether the changes at the Bond Creek site were the result of a landslide in February 1989 or the result of mining is difficult to ascertain. The change in the water-quality conditions in the Bond Creek wells demonstrate, however, the potential for rapid change in these types of hydrogeologic settings. The water-quality characteristics in the Lennox coal and interburden aquifers down the flow gradient from the landslide and mining seem to have been affected soon after the slide. Sulfate concentrations in water from the Lennox coal at the Bond Creek site increased from about $70 \mathrm{mg} / \mathrm{L}$ prior to the landslide to $240 \mathrm{mg} / \mathrm{L}$ within 4 months after the slide (fig. 29). Over the same four -4 period, sulfate concentrations in water from the Bond Creek interburden aquifer increased from about 90 to $280 \mathrm{mg} / \mathrm{L}$. The increase in sulfate concentrations is important because sulfate seems to be the dominant anion in water from reclaimed-spoil aquifers.

As has been noted in the section "Description of Study Area," springs form near the low wall of mine pits. A spring began to flow near the Bond Creek wells within a few months following the landslide. The source of the spring that began to flow within a few months following the landslide is unknown, but because the spoil was not replaced and no reclaimedspoil aquifer existed when the spring began flowing, the source of the spring might be a bedrock aquifer.

Question 2 was, "How fast does snowmelt water flow through the reclaimed spoil?" Snow melts during February and March at the study sites, and water begins entering the soil during these same months (figs. 10-13). The water levels in the reclaimed-spoil aquifers also begin to increase during February and March. Spring discharge also increases at the Spring Creek and Cow Camp Creek sites during the same months. These rapid changes indicate that the hydrol- 
ogy of the reclaimed spoil responds to snowmelt in less than a month.

Question 3 was "Do water quantity and quality change seasonally?" Some components of the hydrologic system indicate seasonal change; examples of these components are spring discharge and the water levels of reclaimed-spoil aquifers. Water quality is another component that can indicate seasonal or longterm fluctuations. However, because only 2 years of data were collected, it cannot be determined if the water-quality changes are truly seasonal. Additional data are needed to determine if seasonal and long-term water-quality trends truly are present.

The water quality at the reclaimed-spoil sites is different from unmined conditions. The dissolvedsolids concentrations are greater than background conditions. The potential maximum dissolved-solids concentrations and the duration of change are issues of concern to mine operators and regulators.

Maximum dissolved-solids concentrations in postmine water at the Seneca II Coal Mine can be approximated from the water quality in samples collected from the lysimeters. The mean dissolved-solids concentration in the lysimeter water at the Spring Creek and Cow Camp Creek sites was 4,300 and $3,400 \mathrm{mg} / \mathrm{L}$, respectively (table 7). At both sites, carbonate and sulfate minerals controlled the dissolvedsolids concentrations, and because these minerals were at or near saturation in both lysimeters (table 9), the dissolved-solids concentrations in post-mine water at the Seneca II Coal Mine probably will not increase substantially.

The two lysimeters have mean dissolved-solids concentrations that differ by nearly $1,000 \mathrm{mg} / \mathrm{L}$. The controlling factor affecting the difference in dissolvedsolids concentration between the lysimeters probably is attributable to different quantities of Lennox coal and the overlying sandstone (samples CLO2 and SS01 in table 16, respectively) in the spoil material at each site. If only the most reactive lithologic unit were included in the reclaimed spoil (sample SS01, table 15) the dissolved-solids concentration could be as large as $9,000 \mathrm{mg} / \mathrm{L}$, as indicated by the batch-mixing experiments. This situation is extremely unlikely but does represent the worst condition based on available data. To reach a dissolved-solids concentration of $9,000 \mathrm{mg} / \mathrm{L}$ at the Seneca II Coal Mine, the $\mathrm{pH}$ would have to be extremely acidic as is the case with sample SS01 (table 17). Because carbonate minerals are prevalent in the area, however, a very acidic $\mathrm{pH}$ in spoilaquifer water is unlikely. If only the least reactive lithologic units are considered, postmine specific conductance could be as low as $600-700 \mu \mathrm{S} / \mathrm{cm}$ (table 15). This condition also is unlikely because the reclaimed spoil is a mixture of several lithologic units, some of which contain highly reactive minerals. Consequently, the chemistry of water collected from the lysimeters represents water that has reacted with a number of different rock types of variable mineralogic content. If the mineralogic content in the rocks of the study area were different, as would probably be the case in a different type of lithology, the dissolved-solids concentrations could be much larger or smaller than the concentrations measured in this study.

Dissolved-solids concentrations are affected by an additional important phenomenon, the inflow of underburden aquifer water. The underburden water dilutes the surface recharge. Consequently, the dissolved-solids concentration in the water in the reclaimed-spoil aquifers and the water that flows from the springs is smaller than that of water collected in the lysimeters. At the Spring Creek and Cow Camp Creek sites, the reclaimed-spoil aquifer and spring water is more dilute in dissolved-solids concentration than the snowmelt (lysimeter) water (table 7). Although lysimeter water might be as much as $5,000 \mathrm{mg} / \mathrm{L}$, the diluting effect of the underburden aquifer water should cause the dissolved-solids concentration in the reclaimedspoil aquifers and the springs to remain at values less than $5,000 \mathrm{mg} / \mathrm{L}$.

Determining the duration of effects on the hydrology of an area following mining is difficult. A mass-balance approach was used to estimate how long the dissolved-solids concentrations at the Seneca II Coal Mine could remain at values in excess of those that existed prior to mining. This mass-balance approach is a rough estimate and requires a number of assumptions. The first assumption is that current climatologic and hydrologic factors will not change substantially in the future. Another assumption is that water percolates uniformly through the reclaimed spoil. A third assumption is that the oxidation of pyrite, which seems to be the ultimate source of dissolved sulfate in the study area, is the primary reaction producing increased dissolved-solids concentrations in reclaimed-spoil aquifer water. Although these assumptions make the following duration predictions subject to debate, the results may provide some indication of the potential duration of effects on water quality following mining.

Dissolved-solids concentrations in reclaimedspoil aquifer water will remain large until the available mass of pyrite is exhausted, if the large dissolved-solids concentrations result from the oxidation of pyrite. The time required to complete oxidation of all pyrite in the reclaimed spoil was calculated from the mass of pyrite and the rate at which pyrite is being oxidized. The calculations use a volume referred to as a spoil unit, a vol- 
ume of reclaimed spoil in an area of $1 \mathrm{ft}^{2}$ and a depth of $50 \mathrm{ft}$. The depth was chosen to represent a mean reclaimed-spoil thickness.

The mass of pyrite in a spoil unit was estimated from available data. The volume of a spoil unit $(1 \mathrm{ft} \times 1 \mathrm{ft} \times 50 \mathrm{ft})$ is $50 \mathrm{ft}^{3}\left(1.4 \times 10^{6} \mathrm{~cm}^{3}\right)$. The estimated bulk density $\left(1.33 \mathrm{~g} / \mathrm{cm}^{3}\right)$ times the volume of a spoil unit yields the mass of solids in a spoil unit, $1.9 \times 10^{6} \mathrm{~g}$. Results for this study indicate pyrite concentrations of as much as 3 percent by weight in some lithologic units (table 15). Pyrite concentrations for the spoil of 0.02 to 3 percent by weight were used in the following calculations.

The sulfate concentration in water leaving a spoil unit, based on lysimeter data, is about $2,700 \mathrm{mg} / \mathrm{L}$. Surface recharge of $3 \mathrm{in} . / \mathrm{yr}$ is about $7.1 \mathrm{~L} / \mathrm{yr}$ recharge to a spoil unit. Therefore, the mass of sulfate leached from a spoil unit is about $19 \mathrm{~g} / \mathrm{yr}$. For every mol of pyrite oxidized (equations 6,7 , and 8 ) $2 \mathrm{~mol}$ of sulfate are produced. The ratio of the mass of $1 \mathrm{~mol}$ of pyrite $(119.98 \mathrm{~g})$ to $2 \mathrm{~mol}$ of sulfate $(192.12 \mathrm{~g})$ indicates that $0.62 \mathrm{~g}(119.98 \mathrm{~g} / 192.12 \mathrm{~g})$ of pyrite is oxidized for each gram of sulfate produced. Therefore, each year an estimated $12 \mathrm{~g}$ of pyrite $(0.6219 \mathrm{~g})$ is oxidized to produce $19 \mathrm{~g}$ of sulfate. The time needed for oxidation of all pyrite is summarized in the table 18.

Table 18. Time required for oxidation of all pyrite in a spoil unit

\begin{tabular}{ccc}
\hline $\begin{array}{c}\text { Pyrite content, } \\
\text { in percent }\end{array}$ & $\begin{array}{c}\text { Pyrite mass, } \\
\text { In grams }\end{array}$ & $\begin{array}{c}\text { Time for } \\
\text { oxidation, } \\
\text { in years }\end{array}$ \\
\hline 3.0 & 57,000 & 5,000 \\
1.0 & 19,000 & 1,600 \\
0.2 & 3,800 & 300 \\
0.02 & 380 & 30 \\
\hline
\end{tabular}

The previous calculations indicate that at present rates of water movement through the reclaimed spoil, a pyrite content of 1 percent by weight in the spoil material can potentially sustain current dissolved-sulfate concentrations in reclaimed-spoil water for hundreds to thousands of years. Even at a pyrite content of 0.2 percent by weight, dissolved-sulfate concentrations would remain at the current level for about 300 years. It needs to be emphasized that the preceding calculations are meant to give duration estimates in terms of orders of magnitude only.

To more accurately determine the duration of chemical change following mining, several variables must be known. For instance, does recharge water flow along specific flow paths, or does it flow uniformly through the reclaimed spoil? Once the flow path is known, the type, quantity, and reactivity of minerals present need to be determined. In addition to knowing flow paths and mineral content, other factors need to be considered. Reclaimed-spoil compaction and plant growth may decrease recharge from snowmelt by increasing runoff and evapotranspiration and thus decrease the quantity of water moving through the reclaimed spoil. Long-term climatic changes also may affect the quantity of recharge to the reclaimed spoil and thereby affect the duration of impact. Following this study period (1990), if ambient climatic and hydrologic conditions do not change substantially, it may be prudent to estimate that dissolved-solids concentrations in the reclaimed-spoil aquifers and associated springs will remain in the 3,000 to $4,000 \mathrm{mg} / \mathrm{L}$ range for hundreds to thousands of years.

\section{TRANSFERABILITY OF FINDINGS}

Because coal is being mined in northwestern Colorado and many other places, it is important to examine the transferability of the findings of this study. The absolute values reported in this study are not directly transferable to other areas. Every mine site will have its own unique set of hydrologic and geochemical characteristics and will need to be evaluated accordingly.

Much of the data presented in this report could be representative of values at other mines in northwestern Colorado if the hydrology and geochemistry are similar to the sites in this study. Rates of snowmelt recharge through the reclaimed spoil could be about $3 \mathrm{in} . / \mathrm{yr}$. The presence and quantity of spring discharge from reclaimed spoil will be a function of the area contributing surface recharge to the reclaimed spoil and the hydraulic characteristics of the underburden bedrock. If the recharge area is small and/or underburden aquifers do not recharge the reclaimed spoil, then springs might not form. Aquifer hydraulic-conductivity values probably will be orders of magnitude less for bedrock aquifers than for reclaimed-spoil aquifers. The water of an area after mining probably will be more mineralized than before mining. However, dissolved-solids concentrations in the reclaimed-spoil aquifer and spring water probably will be less than $5,000 \mathrm{mg} / \mathrm{L}$, especially where underburden aquifers contribute more dilute recharge to the reclaimed-spoil aquifer. The discharge from the reclaimed spoil and effects on water quality in the area might continue for hundreds to thousands of years.

The conceptualizations and techniques used in this study should be transferable to a wide variety of coal-mine settings. However, before using these con- 
cepts and techniques in other areas, a preliminary understanding of the hydrologic and geochemical setting of the area is necessary. The techniques and equipment used in this study are described in this and other reports (Clark and Williams, 1990; Clark and Williams, 1991; Williams and Clark, 1992; Williams and others, 1992). Because every study site has a unique set of hydrologic and geochemical characteristics, modifications to the concepts and techniques used in this study might be necessary.

Coring one well from each study site was a valuable technique because the core was used in several ways to help analyze the hydrogeology and geochemistry of the bedrock. Core initially was used onsite to examine the lithology of the bedrock. The information then was used to ensure proper well completion. Geophysical logs from the cored borehole were compared with geophysical logs from rotary-drilled boreholes to help ensure proper well completion in the rotary-drilled boreholes. Core samples also were used for mineralogic analysis, permeability tests, and batch-mixing experiments. For each experiment, use of the core provided precise information about the location of the source rock within the site lithology.

An appropriate experimental design is critical to the success of any scientific investigation. At the conclusion of the study, some components of the design generally prove more beneficial than others. For this study, the information that was most useful for understanding the hydrogeology and geochemistry of the study area came from analysis of the core samples, underburden aquifer water levels and water quality, reclaimed-spoil aquifer water levels and water quality, and spring discharge and water quality. The springs and two reclaimed-spoil aquifer wells had instruments recording data every one-half hour. Other types of data such as precipitation, soil-water content, and surface recharge are useful, but these data could be available from other nearby sources. If existing data are not sufficiently accurate and reliable to be used in new investigations, then additional data need be collected.

\section{SUMMARY}

The hydrology and geochemistry of the Seneca II Coal Mine, a reclaimed coal mine in northwestern Colorado, were monitored during water years 1988 and 1989 with some data being collected in water years 1987 and 1990. The objectives of the study were to describe (1) the sources of hydrologic recharge to and discharge from reclaimed spoil, (2) the relative contributions of recharge to the reclaimed spoil aquifer from identified source waters and the rate of water movement from those sources to the reclaimed spoil, and (3) the geochemical reactions that control water quality in reclaimed spoil. Monitoring equipment and instrumentation were installed in the summer of 1987.

Climatologic, soil-water, ground-water, geologic, surface-water, and water-quality data were collected at five sites.

The study area was a dip-slope coal mine encompassing about $7 \mathrm{mi}^{2}$ with slopes of varying aspect. The area was instrumented and monitored at five sites; two sites had unmined and reclaimed-spoil areas adjacent to each other, and three sites were unmined. The mined areas had been reclaimed. Instrumentation at the study sites included 1 climate station, 3 rain gages, 19 soilwater access tubes, 2 lysimeters, 18 wells completed in bedrock, 7 wells completed in reclaimed spoil, and 2 surface-water gaging stations.

During the study, the mean air temperature was about $42^{\circ} \mathrm{F}$, and the mean annual precipitation was about 16 in. Water flow through the unsaturated zone of the reclaimed spoil was measured with lysimeters and soil-water access tubes. Discharge from the drainage-type lysimeter at one site was 3.4 in. in water year 1988.

Soil-porosity profiles in reclaimed spoil indicated erratic variations in porosity with depth, whereas the porosity profiles at an undisturbed site indicated uniformly decreasing porosity with depth. Soil-water content increased rapidly in the reclaimed spoil after spring snowmelt and then decreased gradually during the remainder of the year. The soil-water content in undisturbed soil did not increase as rapidly as in the reclaimed spoil after snowmelt, but soil-water content in the undisturbed soil decreased more rapidly during the growing season compared to the reclaimed soils.

Ground-water wells were installed in reclaimedspoil aquifers and in bedrock aquifers. Aquifers in the reclaimed spoil were unconfined. Water levels in the reclaimed-spoil aquifers rose in the spring following snowmelt. Wells were completed in bedrock at four sites-the Lennox coal, the interburden, the Wadge coal, and the underburden. All the wells completed in the bedrock aquifer at the study sites flowed at land surface. In general, the deeper the bedrock aquifer, the greater the water level indicating the potential for upward vertical movement of water from underburden aquifers to the reclaimed spoil.

Aquifer tests were done at all of the wells completed in bedrock and at two of the wells completed in reclaimed spoil. In general, hydraulic-conductivity values for the reclaimed-spoil aquifers were greater than those for the bedrock aquifers or for the bedrock core samples tested in the laboratory. The larger hydraulic-conductivity values in the reclaimed spoil is a major factor in the formation of reclaimed-spoil aquifers and associated springs. Water infiltrates the 
reclaimed spoil faster than it can discharge to the bedrock surrounding the reclaimed spoil. Consequently, the reclaimed spoil fills with water forming an aquifer and, eventually, a spring.

Spring discharge from reclaimed-spoil aquifers was continuously monitored during the study. Discharge fluctuations in the reclaimed-spoil springs coincided with the rise and fall of the water table in the reclaimed-spoil aquifers.

Four geochemical processes control the chemical evolution of ground water in the study area. These include recharge and percolation of snowmelt water that contains $\mathrm{CO}_{2}$ and $\mathrm{O}_{2}$ gases, dissolution and precipitation of carbonate and sulfate minerals, oxidation of pyrite, and cation-exchange reactions.

A range of water types occurs at the study sites. The water type determined in unmined bedrock aquifers in areas undisturbed by mining is sodium bicarbonate with dissolved-solids concentrations ranging from 400 to $1,300 \mathrm{mg} / \mathrm{L}$. The water type in the lysimeters, reclaimed-spoil aquifers, and springs is a calcium magnesium sulfate type with dissolved-solids concentrations ranging from 2,500 to $4,500 \mathrm{mg} / \mathrm{L}$. The water quality in bedrock aquifers near the margins of the reclaimed spoil is an intermediate type composition of the undisturbed and disturbed water types.

Mineral-water equilibrium models were used to determine saturation indices for water samples collected at the study sites. Most of the water samples were at or near saturation with respect to calcite and dolomite. Water samples from aquifers unaffected by mining were substantially undersaturated with respect to sulfate minerals; however, water from the lysimeters, reclaimed-spoil aquifers, and springs were at or near saturation with respect to sulfate minerals.

Two sites, Zuli and Bond Creek, were unmined and had only wells completed in bedrock installed. The water quality in the aquifers at the Zuli site were indicative of undisturbed conditions. All the water samples collected from the wells at the Zuli site were a sodium bicarbonate type. At the Bond Creek site, a landslide occurred in February 1989. The dissolved-sulfate and dissolved-solids concentrations in water from the Lennox coal and interburden aquifers increased substantially soon after the landslide. However, it is difficult to determine whether the changes in hydraulic and water-quality characteristics at the Bond Creek wells were the result of the landslide or the result of mining activity.

The water quality at the Spring Creek and Cow Camp Creek sites is similar. The water type at both sites is a calcium magnesium sulfate type; however, the dissolved-solids concentrations are consistently larger in the lysimeter, reclaimed-spoil aquifer, and spring at the Spring Creek site. The difference in dissolvedsolids concentrations between the Spring Creek and Cow Camp Creek sites probably is because of a greater quantity of Lennox coal and sandstone over-lying the Lennox coal in the spoil at the Spring Creek site. The Lennox coal and the overlying sandstone contain large quantities of pyrite, which upon oxidation contributes large quantities of dissolved solids to mine-site water.

Isotopes of hydrogen (tritium and deuterium) and oxygen were collected from the lysimeters, selected wells, and the springs to help determine sources of recharge water to the reclaimed-spoil aquifer. Results of mixing calculations using stable-isotope ratios indicate that the reclaimed-spoil aquifer is about a 50:50 mix of soil-water recharge and underburdenaquifer recharge.

Identification and quantification of mineralwater interactions in undisturbed and reclaimed-spoil aquifers were evaluated by using a mass-balance model. Simulations of mineral-water interactions in the underburden aquifers indicate that dissolution of $\mathrm{CO}_{2}$ gas and dolomite and cation-exchange reactions are the primary mechanisms whereby underburdenaquifer water obtains dissolved constituents. Simulation results for water percolating through the reclaimed spoil indicate that gypsum and epsomite, which are probably concentrated as amorphous efflorescent salts, contribute most of the dissolved solids in the lysimeter water. Simulations for the reclaimed-spoil aquifer indicate that most of the dissolved solids in the aquifer are from percolating soil water recharging the aquifer. However, the simulations for the reclaimed-spoil aquifer also indicate that the water quality in the aquifer is modified by recharge from underburden aquifers, which contribute about 50 percent of the recharge to the reclaimed-spoil aquifer.

Batch-mixing experiments were done by using sections of core from the cored borehole at Cow Camp Creek. X-ray diffraction analyses of the core indicated that pyrite was present in small quantities throughout most of the lithology in the study area. Results of the batch-mixing experiments indicate that a large change can occur in the water chemistry of the batch-mixing water from 1 to 90 days of water-rock contact.

Three lithologic units contained in the Wadge coal overburden probably contribute a large part of the dissolved solids to the reclaimed-spoil aquifer. The units are the sandstone above the Lennox coal, the Lennox coal, and a shale unit above the Wadge coal. The Lennox coal and overlying sandstone contain large quantities of pyrite, which upon oxidation, release acid and dissolved sulfate. The acid released has a corrosive effect on the carbonate rocks in the reclaimed spoil, thus dissolving calcium, magnesium, and carbonate 
ions into spoil-affected water. The shale unit above the Wadge coal probably contains amorphous salts of gypsum and epsomite, which dissolve rapidly on contact with ground water.

A mass-balance approach was used to calculate the quantity of water recharged to the reclaimed-spoil aquifer from soil-water recharge and underburdenaquifer recharge. Results of the calculations indicate that about 50 percent of the water in the reclaimedspoil aquifer comes from soil-water recharge and 50 percent comes from underburden-aquifer recharge.

Dissolved-solids concentrations in water at the Seneca II Coal Mine probably will remain at less than $4,000 \mathrm{mg} / \mathrm{L}$ if hydrologic conditions remain the same. The duration of time for the dissolved-solids concentrations to remain affected is difficult to determine. A mass-balance approach indicates that enough minerals are present in the reclaimed spoil to maintain dissolved-solids concentrations in the 3,000 to $4,000 \mathrm{mg} / \mathrm{L}$ range for hundreds to thousands of years.

The conceptualizations and techniques used in this study should be transferable to a wide variety of coal-mine settings. However, data results from this study should only be used if hydrologic and geochemical characteristics at other mines are similar to those at the Seneca II Coal Mine. Each area will have distinct hydrologic and geochemical features that need to be considered before using the concepts, techniques, and data presented in this report.

\section{REFERENCES CITED}

Aller, Linda, Bennett, T.W., Hackett, Glen, Petty, R.J., Lehr, J.H., Sedoris, Helen, Nielsen, D.M., and Denne, J.E., 1989, Handbook of suggested practices for the design and installation of ground-water monitoring wells: U.S. Environmental Protection Agency Report EPA 600/4-89/034, $398 \mathrm{p}$.

Barcelona, M.J., Gibb, J.P., Helfrich, J.A., and Garske, E.E., 1985, Practical guide for ground-water sampling: U.S. Environmental Protection Agency Report EPA/600/ 2-85/104, 169 p.

Bass, N.W., Eby, J.B., and Campbell, M.R., 1955, Geology and mineral fuels of parts of Routt and Moffat Counties, Colorado: U.S. Geological Survey Bulletin 1027-D, p. 143-250.

Campbell, M.D., and Lehr, J.H., 1973, Water well technology: New York, McGraw-Hill, 681 p.

Clark, G.M., and Williams, R.S., Jr., 1990, Hydrologic and geochemical characterization of recharge and groundwater flow in a reclaimed-coal-mined-land, northwestern Colorado, in Fifth Billings Symposium on Disturbed Land Rehabilitation-volume II, Hazardous waste management; wildlife; hydrology; drainages, erosion and wetlands; soils, minesoils and overburden; linear disturbances; oil and gas [1990 Proceedings]: Bozeman, Montana State University, Reclamation Research Unit Publication 9003, p. 173-185.

1991 , Identification of dissolved-constituent sources in mine-site ground water using batch mixing: Water Resources Bulletin, v. 27, no. 1, p. 93-100.

Davis, R.E., 1984, Geochemistry and geohydrology of the West Decker and Big Sky coal-mining areas, southeastern Montana: U.S. Geological Survey WaterResources Investigations Report 83-4225, 109 p.

Davis, R.E., and Dodge, K.A., 1986, Results of experiments related to contact of mine-spoils water with coal, West Decker and Big Sky mines, southeastern Montana: U.S. Geological Survey Water-Resources Investigations Report 86-4002, 16 p.

Davis, S.N., and DeWiest, R.J., 1966, Hydrogeology: New York, Wiley, $463 \mathrm{p}$.

Day, M.J., Mills, R.A., and Nalven, J.G. 1987, Predicting the influences of post-mining conditions on surface and groundwater resources, in Water resources related to mining and energy-Preparing for the future, Anchorage, 1987, Proceedings: Bethesda, Md., American Water Resources Association, p. 483-500.

Dunne, Thomas, and Leopold, L.B., 1978, Water in environmental planning: San Francisco, W.H. Freeman and Company, $818 \mathrm{p}$.

Driscoll, F.G., 1986, Groundwater and wells (2d ed.): St. Paul, Johnson Division, 1,089 p.

Emrich, C.H., and Merritt, G.L., 1969, Effects of mine drainage on groundwater: Ground Water, v. 7, no. 3, p. 27-32.

ENMAP Corporation, 1981, Guide to Colorado's weather and climate: Boulder, Colo., map pamphlet.

Eriksson, E., 1985, Principles and applications of hydrochemistry: New York, Chapman and Hall, 187 p.

Freeze, R.A., and Cherry, J.A., 1979, Groundwater: Englewood Cliffs, N.J., Prentice-Hall, 604 p.

Gat, J.R., 1980, The isotopes of oxygen and hydrogen in precipitation, in Fritz, Peter, and Fontes, J.C. eds., Handbook of environmental isotope geochemistry, part AThe terrestrial environment; New York, Elsevier, p. 21-47.

Groenewold, G.H., Koob, R.D., McCarthy, G.J., Rehm, B.W., and Peterson, W.M., 1983, Geological and geochemical controls on the chemical evolution of subsurface water in undisturbed and surface-mined landscapes in western North Dakota: North Dakota Geological Survey Report of Investigations 79, various pagination.

Hounslow, Arthur, Fitzpatrick, Joan, Cerrillo, Lawrence, and Freeland, Michael, 1978, Overburden mineralogy as related to ground-water chemical changes in coal strip 
mining: U.S. Environmental Protection Agency Report 600/7-78-156, $229 \mathrm{p}$.

Jackson, M.L., 1979, Soil chemical analysis-Advanced course ( $2 \mathrm{~d}$ ed.): Madison, Wis., Published by the Author, 895 p. [11th printing]

Klinkenberg, L.J., 1941, The permeability of porous media to liquids and gases: API, Drilling and Production Practice, May, p. 200-213.

Linsley, R.K., Kohler, M.A., and Paulhus, J.L.H., 1975, Hydrology for engineers ( $2 \mathrm{~d}$ ed.): New York, McGrawHill, 483 p.

McWhorter, D.B., Skogerboe, R.K., and Skogerboe, G.V., 1975, Water quality control in mine spoils Upper Colorado River basin: U.S. Environmental Protection Agency Report EPA-670/2-75-048, 99 p.

Muir, K.S., and Coplen, T.B., 1981, Tracing ground-water movement by using the stable isotopes of oxygen and hydrogen, Upper Penitencia Creek alluvial fan, Santa Clara Valley, California: U.S. Geological Survey Water-Supply Paper 2075, 18 p.

Naftz, D.L., 1988, Predictive capabilities of batch-extract experiments using water from a coal mine: Water Resources Bulletin, v. 24, no. 4, p. 869-877.

Nathan, R.J., and McMahon, T.A., 1990, Evaluation of automated techniques for base flow and recession analysis: Water Resources Research, v. 26, no. 7, p. 1465-1473.

Parkhurst, D.L., Plummer, L.N., and Thorstenson, D.C., 1982, BALANCE-A computer program for calculating mass transfer for geochemical reactions in ground water: U.S. Geological Survey Water-Resources Investigations Report 82-14, 33 p.

Plummer, L.N., Jones, B.F., and Truesdell, A.H., 1976, WATEQF-A FORTRAN IV version of WATEQ, a computer program for calculating chemical equilibrium of natural waters: U.S. Geological Survey WaterResources Investigations 76-13, 66 p.
Rao, C.P., and Gluskoter, H.J., 1973, Occurrence and distribution of minerals in Illinois coals: Illinois State Geological Survey Circular 476, 56 p.

Raush, H.W., and White, W.B., 1977, Dissolution kinetics of carbonate rocks, Part I, Effects of lithology on dissolution rate: Water Resources Research, v. 13, p. 381-394.

Stumm, W., and Morgan, J.J., 1981, Aquatic chemistry: New York, Wiley, 780 p.

Tweto, Ogden, 1976, Geologic map of the Craig 12 quadrangle, northwestern Colorado: U.S. Geological Survey Miscellaneous Investigations Series Map I-972, scale 1:250,000.

U.S. Bureau of Reclamation, 1977, Ground water manualA water resources technical publication: Washington, D.C., U.S. Government Printing Office, 480 p.

U.S. Environmental Protection Agency, 1990, Drinking water regulations and health advisories: Washington, D.C., Office of Drinking Water, April 1990, 13 p. [Updated biannually].

Williams, R.S., Jr., and Clark, G.M., 1992, Description of techniques used to drill, complete, and develop wells and to test and sample aquifers at a surface coal mine in northwestern Colorado: U.S. Geological Survey Water-Resources Investigations Report 92-4067, $39 \mathrm{p}$.

Williams, R.S., Jr., Clark, G.M., and Spahr, N.E., 1992, Climatologic, soil-water, ground-water, geologic, surfacewater, and water-quality data for a surface coal mine in northwestern Colorado: U.S. Geological Survey OpenFile Report 92-122, 218 p.

Williams, R.S., Jr., and Hammond, S.E., 1988, Soil-water hydrology and geochemistry of a coal spoil at a reclaimed surface mine in Routt County, Colorado: U.S. Geological Survey Water-Resources Investigations Report 86-4350, 100 p. 